\title{
24- Türkçenin yabancı dil olarak öğretiminde kullanılan okuma kitaplarındaki söz varlı̆̆ı ögelerinin incelenmesi
}

\section{Meryem GÖKER²}

\section{Gökçen GÖÇEN3}

APA: Göker, M.; Göçen, G. (2021). Türkçenin yabancı dil olarak öğretiminde kullanılan okuma kitaplarındaki söz varlığı ögelerinin incelenmesi. RumeliDE Dil ve Edebiyat Araşttrmaları Dergisi, (Ö10), 407-446. DOI: 10.29000/rumelide.1011968.

$\ddot{O} \mathbf{z}$

Sözcükler iletişimi sağlayan temel ögeler olarak kabul edilmektedir. Yalnız veya birkaç sözcüğün birleşimiyle varlık gösteren söz varlığı ögeleri, bir dilin yabancı dil olarak öğretilmesi sürecinde öncelikler ve ihtiyaçlara göre öğreniciye sunulmalıdır. Ancak bu şekilde etkili ve faydalı bir öğrenmeden söz edilebilir. Türkçenin yabancı dil olarak öğretiminde öncelik verilecek söz varlı̆̆ı ögelerinin tespiti, sözcük sıklı̆̆ı çalışmalarıyla mümkün olmaktadır. Sözcük sıklığı çalışmaları, seviyelere göre kapsamlı sözcük listelerinin hazırlanmasına veri oluşturduğundan bu bağlamda yapılacak çalışmaların alanyazına katkı sağlayacağı düşünülmektedir. Buna bağlı olarak Türkçenin yabancı dil olarak öğretiminde hâlihazırda kullanılmakta olan kitapların incelenmesinin gerekli olduğu görülmektedir. Belirtilen gereklilik bağlamında bu çalışma Türkçenin yabancı dil olarak öğretiminde kullanılan, B2-C1 seviyesindeki öğreniciler için hazırlanmış, özgün metinler içeren “Türkçe Öğrenen Yabancılar için Türk Edebiyatı Antolojisi” adlı eserin söz varlığı unsurlarının tespiti ve kullanım sıklığının belirlenmesi amacıyla gerçekleştirilmiştir. Çalışmada nitel araştırma yöntemlerinden durum çalışmasına başvurulmuştur. Yazılı metinlerin bilgisayar ortamına aktarılması ve dinleme metinlerinin yazıya geçirilmesi aşamalarının ardından doküman incelemesiyle elde edilen verilerin analizinde CİBAKAYA 2.0 programından yararlanılmıştır. Bu çerçevede, incelenen eserdeki söz varlığı unsurları; sözcükler, ikilemeler, deyimler ve atasözleri kategorileri içerisinde değerlendirilmiştir. Elde edilen veriler ışı̆̆ında söz varlı̆̆ı unsurlarının neler olduğu ve bunların kullanım sıklıkları tablolar hâline getirilmiştir. Çalışma sonucunda, incelenen okuma kitabında en çok "sözcük" kategorisindeki söz varlığı unsurlarının yer aldı̆̆ı; bunu sırasıyla deyimlerin, ikilemelerin ve atasözlerinin takip ettiği görülmüştür. Atasözlerinin sayısının oldukça az olduğu, bunun yanında günlük kullanımda sık başvurulmadığı hâlde incelemede sıklık düzeyi yüksek çıkan söz varlığı unsurlarının da bulunduğu fark edilmiştir. İncelenen okuma kitabının Türkçeyi yabancı dil olarak öğrenenlerin sözcük dağarcığına katkı sağlayacağı düşünülmektedir.

Anahtar kelimeler: Türkçenin yabancı dil olarak öğretimi, yabancılar için Türkçe okuma kitapları, sözcük öğretimi, söz varlığı, sözcük sıklı̆̆ı

$1 \quad$ Bu çalışma 10-11 Eylül 2021 tarihlerinde düzenlenen "7. Uluslararası Yabancı Dil Olarak Türkçe Öğretimi Kongresi"nde sözlü bildiri olarak sunulmuştur

Öğr. Gör., İstanbul Medipol Üniversitesi, Türkçe Hazırlık Koordinatörlüğü (İstanbul, Türkiye), meryem.goker@medipol.edu.tr, ORCID ID: 0000-0001-5512-4017 [Araştırma makalesi, Makale kayıt tarihi: 26.09.2021kabul tarihi: 20.10.2021; DOI: 10.29000/rumelide.1011968]

3 Doç. Dr., Fatih Sultan Mehmet Vakıf Üniversitesi, Türkçe Eğitimi ABD (İstanbul, Türkiye). ggocen@fsm.edu.tr, ORCID ID: 0000000175528406

RumeliDE Dil ve Edebiyat Araştırmaları Dergisi Osmanağa Mahallesi, Mürver Çiçeği Sokak, No:14/8 Kadıköy - ISTANBUL / TÜRKIYE 34714 e-posta: editor@rumelide.com tel: +90 $5057958124,+902167730616$
Address

RumeliDE Journal of Language and Literature Studies Osmanağa Mahallesi, Mürver Çiçeği Sokak, No:14/8

Kadıköy - ISTANBUL / TURKEY 34714

e-mail: editor@rumelide.com,

phone: +90 505 7958124, +90 2167730616 


\title{
Examination of vocabulary items in reading books used in teaching Turkish as a foreign language
}

\begin{abstract}
Words are accepted as the basic elements that provide communication. Vocabulary items that exist alone or with a combination of a few words should be presented to the learner according to priorities and needs in the process of teaching a language as a foreign language. Only in this way can we talk about effective and beneficial learning. The determination of the vocabulary items that will be given priority in teaching Turkish as a foreign language is possible with word frequency studies. Since the word frequency studies provide data for the preparation of comprehensive word lists according to the levels, it is thought that the studies to be carried out in this context will contribute to the literature. Accordingly, it is seen that it is necessary to examine the books that are currently used in teaching Turkish as a foreign language. In the context of the stated necessity, this study was carried out in order to determine the vocabulary elements of the work called "Turkish Literature Anthology for Foreigners Learning Turkish", which is used in teaching Turkish as a foreign language, prepared for B2-C1 level learners, and contains original texts. Case study, one of the qualitative research methods, was used in the study. CIBAKAYA 2.0 program was used in the analysis of the data obtained by document analysis after the stages of transferring the written texts to the computer environment and translating the listening texts into writing. In this context, the vocabulary elements in the studied work; words were evaluated in the categories of reduplications, idioms and proverbs. In the light of the data obtained, what the vocabulary elements are and their frequency of use have been tabulated. As a result of the study, it was found that the vocabulary elements in the "word" category were the most in the reading book; idioms, reduplications and proverbs followed respectively. It has been noticed that the number of proverbs is quite low, and that there are also vocabulary elements that have a high level of frequency in the examination, although they are not frequently used in daily use. It is thought that the examined reading book will contribute to the vocabulary of those who learn Turkish as a foreign language.
\end{abstract}

Keywords: Teaching Turkish as a foreign language, Turkish reading books for foreigners, vocabulary teaching, vocabulary, word frequency

\section{Giriş}

Ana dili ediniminde, yabancı dil öğreniminde ve merkezi dil olan pek çok meselede özü "sözcük" oluşturmaktadır. Türkçenin yabancı dil olarak öğretiminde öğrenicilere dinleme, konuşma, okuma ve yazma becerilerinin kazandırılması konusu dil öğretimi sürecinin merkezinde yer almaktadır. Bu dört dil becerisinin kazandırılması sürecinin öncesinde, süreç devam ederken ve yeni öğrenmeler gerçekleşirken sürece eşzamanlı bir şekilde dâhil olan sözcük öğretimi/öğrenimi kavramı ile karşılaşılmaktadır. Sözcüklerin iletişimi sağlayan araçlar olduğu düşünüldüğünde yabancı dil öğretimi dizgesini oluşturan yaklaşım, yöntem, dört dil becerisi, dil bilgisi, materyal, teknoloji gibi kesitlerden birinin de sözcük öğrenimi/öğretimi olduğu söylenebilir. Nitekim Harmer’a (1997'den akt. Dilidüzgün, 2019, s. 414) göre, dilin iskeleti dil yapılarından oluşuyorsa sözcük dağarcığı en önemli organı ve etini temin etmektedir. Harmer'ın bu ifadesi, yabancı dilde sözcük öğrenmenin ne derece önem teşkil ettiğini de göstermektedir. Harmer'ın de önemini dile getirdiği sözcük dağarcı̆̆ı kavramı Vardar (2002, s. 182) tarafından "Bir bireyin kullandığı ya da bir bütüncede yer alan sözcüklerin tümü.” şeklinde tanımlanmaktadır. Mete (2014, s. 113) ise bireylerin dil becerilerinin etkin kullanımının zengin sözcük

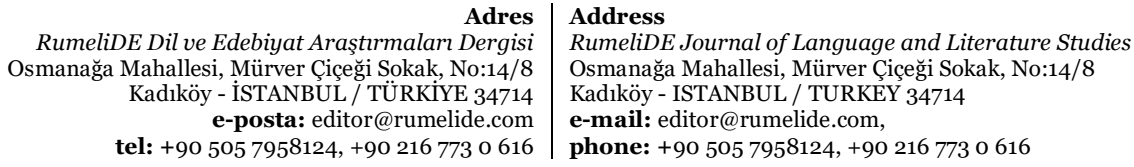


hazinesi, diğer bir ifade ile sözcük dağarcığına bağlı olduğunu ve bu birikimin sadece sözcükler değil kültürel birikimi de yansıtan atasözleri, deyim ve deyişlerden oluştuğunu ifade etmektedir. Yabancı dil olarak Türkçenin öğretimi/öğrenimi sürecinde öğrenicinin söz varlığı ögeleriyle karşılaşıp öğreneceği ve “anlamlı girdi” hâline gelecek sözcük dağarcığının niteliği-niceliği ve bunu edinme şekli, üzerinde durulması gereken bir meseledir.

Yabancı dil öğrenmek, öğrenilen dilin kültürünü dolayısıyla toplumsal algı ve değerlerini tanımayı da beraberinde getirmektedir. Özellikle tarihin ve değerlerin taşıyıcısı olan sözcüklerin, atasözlerinin ve mecaz anlamlarla -gerçek anlamın bir adım ötesinde- toplumsal algılara ilişkin ipuçları taşıyan deyimlerin bu algı ve değer transferindeki etkisi azımsanmayacak derecede kabul edilmektedir. Bu bağlamda Aksan (2008, s. 21) da "Anadolu'yu ve Türkçe konuşulan öteki ülkeleri hiç bilmeyen bir yabancı, dünyanın herhangi bir yerinde iyi bir Türkçe öğrenimiyle bu dili öğrenecek olsa yalnızca sözvarlığını inceleyerek Türk kültürü üzerinde pek çok bilgi edinebilecek, uzakta olduğu hâlde bu kültürü tanıyacaktır." görüşündedir. Bu görüşten hareketle yabancı dil öğretiminin aynı zamanda kültür aktarım süreci olduğu, bu süreçte ise sözvarlı̆̆ı unsurlarının bir bölümünü oluşturan deyim ve atasözlerinin diğer sözcük türlerine ek olarak önemli bir rol üstlendiği söylenebilir. Barın (2004, s. 25) da deyimlere günlük kullanımda çok yer verildiği için deyimlerin iyi öğretilmesi gerektiğini düşünmektedir. Bu çerçevede Tüm’ün (2010, s. 669) "Söz varlığı içerisinde kültürel eğilimleri yansıtan deyimler, dilin kullanımını ve kültürün anlaşılmasını kolaylaştırır.” görüşü ise söz varlığını oluşturan sözcüklere ek olarak deyim, atasözü, ikilemelerin öğretilmesinin yabancı dil olarak Türkçenin öğretimindeki gerekliliğini destekler niteliktedir.

Siyanova-Chanturia ve Webb (2016, s. 227) sözcük öğreniminin tesadüfi olarak gerçekleşmesinin sınırlı olduğunu, sık kullanılan sözcüklerin öğreniminin daha ziyade sınıf eğitimiyle gerçekleştiğini belirtir. Bu görüşten hareketle yabancı dil eğitimi süreçlerinde dil sınıflarında ve sınıf dışı etkinliklerde kullanılacak okuma kitaplarının niteliği, söz varlığı ve zenginliği sözcük öğretimi açısından değerlendirilmesi gereken materyaller olarak kabul edilebilir. Değerlendirmenin gerçekleştirilmesi aşamasında ise "sözcük sıklı̆̆ı" kavramı ile karşlaşılmaktadır.

Sözcük sıklı̆̆ı Türkçe Sözlük’te (2011) “Dilde bir sözün kullanılma oranı.” olarak tanımlanmaktadır. Yabancı dil öğretiminde/öğreniminde de en çok kullanılan ve en çok ihtiyaç duyulan sözcüklerin öğrenilmesine/öğretilmesine öncelik verileceği hesaba katıldığında sözcük sıklı̆̆ı çalışmalarının yapılmasının ve bu çalışmaların yabancı dil öğretimi sürecinde dikkate alınmasının gerekli olduğu sonucuna ulaşılmaktadır. Nitekim Vardar (2002, s. 175) da sıklık çalışmalarının yabancı dil öğretimi alanında öğretilecek ögelerin belirlenmesine ve dil öğretimi alanında yöntemlerin geliştirilmesine katkı sağladığını vurgulamaktadır.

Alanyazın incelendiğinde Türkçenin yabancı dil olarak öğretiminde kullanılan ders ve okuma kitaplarının söz varlığının tespitinde sözcük sıklı̆̆ çalışmalarının gerçekleştirildiği görülmektedir (Alsarray, 2015; Bilgiç, 2016; Göçen, 2016; Kılıç, 2017; Şenyiğit, 2020). Yapılan çalışmalar, sözcük öğretimi içeriğinin şekillenmesine ilişkin kaynak niteliği taşımakla birlikte alanyazında bu bağlamda ortak bir anlayışın tam anlamıyla benimsenmediği de görülmektedir. Türkçenin yabancı dil olarak öğretiminde öncelik verilecek sözcükler ile sözcük öğretimi hususunda ortak bir anlayışa ulaşılması ise Göçen ve Okur'un (2019) da vurguladığı gibi ancak daha fazla sayıda yabancılar için Türkçe kitabının ve öğrenenlerin sözcük kullanımlarının incelenmesi ile mümkün görülmektedir.

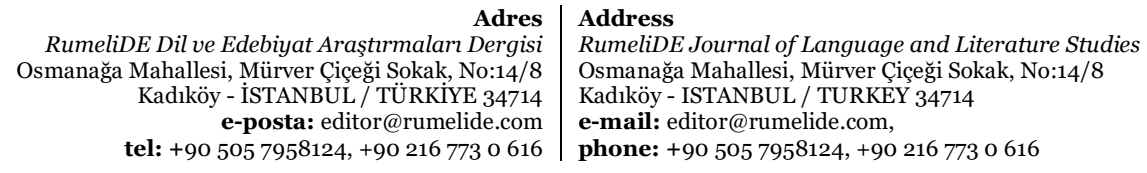

RumeliDE Dil ve Edebiyat Araştırmaları Dergisi Kadı̈̈̈y - ISTANBU̧ / TÜRKiYE 34714 tel: +90 505 7958124, +902167730616 
Türkçenin yabancı dil olarak öğretiminde "Neyi, ne kadar, nasıl, ne zaman, ne aracılı̆̆ıyla öğreteceğiz?" sorularına cevap olmak gayesiyle çalısmalar yürütülmektedir. Bu çalışma ise "Neyi öğreteceğiz?” sorusuna cevap verme gayesi taşımaktadır. Bu araştırmanın problem cümlesini "Türkçenin yabancı dil olarak öğretiminde kullanılan okuma kitaplarında yer alan söz varlı̆̆ı ögeleri nelerdir?” sorusu oluşturmaktadır. Çalışmada, Türkçenin yabancı dil olarak öğretiminde kullanılan okuma kitaplarında yer alan söz varlı̆̆ ögelerinin tespit edilmesi amaçlanmaktadır. Esas alınan amaç çerçevesinde şu sorulara cevap aranmaktadır:

1. İncelenen kitapta yer alan toplam ve farklı sözcüklerin, ikilemelerin, deyimlerin ve atasözlerinin sayısı nedir?

2. İncelenen kitapta yer alan sözcükler hangileridir?

3. İncelenen kitapta yer alan ikilemeler hangileridir?

4. Incelenen kitapta yer alan deyimler hangileridir?

5. İncelenen kitapta yer alan atasözleri hangileridir?

\section{Yöntem}

\subsection{Araştırmanın modeli}

Çalışmada nitel araştırma desenlerinden durum çalışmasına başvurulmuştur. Yıldırım ve Şimşek’in (2016, s. 77) de ifade ettiği üzere nitel durum çalışmasının en temel özelliği bir ya da birkaç durumun derinliğine araştırılmasıdır. Bu çalışmada ise incelenen eserin söz varlığı ve sözcük sıklığı durumu ele alınmıştır.

\section{2. İncelenen doküman}

Çalışmada, İstanbul Medeniyet Üniversitesi Yayınları tarafından yayınlanan, akıllı tahta uyumlu "Türkçe Öğrenen Yabancılar İçin Türk Edebiyatı Antolojisi” isimli eser incelenmiştir. Eserde Türk edebiyatında önde gelen yazarların eserlerine yer verilmiştir. Dolayısıyla metinler dil öğretim ortamlarında kullanılmak üzere oluşturulmuş yapay metinler değil, edebî hassasiyetlerle örülü özgün metinlerden oluşmaktadır. Eserde 19 adet okuma metni yer almaktadır. Bu 19 okuma metnine ek olarak okuma öncesi ve okuma sonrası etkinliklerde de çeşitli türlerde metinlerden faydalanılmıştır. Eserde yer verilen 19 okuma metni şunlardır:

Tablo 1. Eserde yer alan ana okuma metinleri

\begin{tabular}{|c|c|}
\hline Metinlerin Adı & Metinlerin Yazarı \\
\hline Arkadaşını İyi Seç & Mevlânâ Celâleddîn-i Rûmî \\
\hline Asuman ile Zeycan & Anonim \\
\hline Gülperi Civan Hanım & Anonim \\
\hline Viyana'da Beyin Ameliyatı & Evliyâ Çelebi \\
\hline Perili Köşk & Ömer Seyfettin \\
\hline Hayat Ne Tatlı & Memduh Şevket Esendal \\
\hline Arabalar Beş Kuruşa & Sabahattin Ali \\
\hline Çanta & Ali Ayçil \\
\hline Elli Kuruş & Orhan Kemal \\
\hline $\begin{array}{r}\text { Adres } \\
\text { RumeliDE Dil ve Edebiyat Araştrrmaları Dergisi } \\
\text { Osmanağa Mahallesi, Mürver Çiç̌ği Sokak, No:14/8 } \\
\text { Kadıköy - İSTANBUL / TÜRKIYE 34714 } \\
\text { e-posta: editor@rumelide.com } \\
\text { tel: +90 505 7958124, +90 216 773 0 616 }\end{array}$ & $\begin{array}{l}\text { Address } \\
\text { RumeliDE Journal of Language and Literature Studies } \\
\text { Osmanağa Mahallesi, Mürver Çiçeği Sokak, No:14/8 } \\
\text { Kadıöy - ISTANBUL / TURKEY } 34714 \\
\text { e-mail: editor@rumelide.com, } \\
\text { phone: +90 505 7958124, +90 } 216773 \text { o } 616\end{array}$ \\
\hline
\end{tabular}




\begin{tabular}{ll} 
Ümit Dünyası & Şevket Rado \\
\hline Mukaddes Hatıra & Reşat Nuri Güntekin \\
\hline Elli Beşinci Mektup & Ahmet Rasim \\
\hline Zeynep Kadın & Yakup Kadri Karaosmanoğlu \\
\hline Ali Cengiz Oyunu & İskender Pala \\
\hline Eskici & Refik Halit Karay \\
\hline Son Kuşlar & Sait Faik Abasıyanık \\
\hline Mücella & Nazan Bekiroğlu \\
\hline Çiğdem Güzeli & Mustafa Kutlu \\
\hline Birinci İkramiye & Ahmet Hamdi Tanpınar \\
\hline
\end{tabular}

Tablo 1'de yer alan 19 okuma metnine ek olarak her metin için ayrı ayrı okuma öncesi ve okuma sonrası etkinlikleri hazırlanmış, bu etkinlikler bağlamında ise yine Türk edebiyatına ait mektup, deneme, şiir gibi edebî metinlere yer verilmiştir. Ayrıca eserde 17 adet dinleme-izleme metnine yer verilmiştir. Çalışmada, eseri oluşturan tüm ögeler analiz edilmiştir.

\subsection{Veri toplama süreci ve aracı}

Nitel araştırmalarda gözlem, görüşme ve doküman analizi gibi farklı kaynaklardan elde edilen veriler önce incelenerek kodlanır ve sonra kodlamalar dikkate alınarak bulgulara ulaşılır (Büyüköztürk, Kılıç Çakmak, Akgün, Karadeniz ve Demirel, 2017). Bu çalışmada, B2-C1 seviyesine yönelik olarak hazırlanmış "Türkçe Öğrenen Yabancılar İçin Türk Edebiyatı Antolojisi" isimli eserin söz varlığı ögelerinin tespit edilmesi amacıyla nitel araştırma tekniklerinden doküman analizine başvurulmuştur.

Çalışmanın ilk aşamasında, yabancılara Türkçe öğretmek amacıyla hazırlanmış, özgün metinler içeren “Türkçe Öğrenen Yabancılar İçin Türk Edebiyatı Antolojisi” eserine ulaşılmıştır. Ardından kitabın bilgisayar ortamına aktarılması sağlanmıştır. Yazılı metinlerin aktarılmasının ardından dinleme metinlerinin yazıya geçirilmesi aşaması gerçekleştirilmiş̧ir. Bu yol ile "Türkçe Öğrenen Yabancılar İçin Türk Edebiyatı Antolojisi” kitabının hem yazılı metinleri hem de dinleme metinlerini içeren bir sözcük havuzu elde edilmiştir. Çalışma kapsamında bilimsel araştırma ve yayın etik ilkelerine uyulmuştur.

\subsection{Verilerin analizi}

"Türkçe Öğrenen Yabancılar İçin Türk Edebiyatı Antolojisi” isimli kitabın analiz edilmesinde içerik analizi esas alınmıştır. Çalışmanın temelini oluşturan sözcük sıklıklarının tespitinde CİBAKAYA 2.0 programından yararlanılmıştır. Bilgisayar ortamına aktarılan ve sözcük havuzu oluşturulan kitabın CIBAKAYA programı analizine hazırlanması sürecinde, Göçen’in (2016) doktora çalışmasında CIBAKAYA programına ilişkin paylaştığı bilgiler rehber görevi görmüştür. Çalışma; Baş’ın (2011) tasnif ettiği söz varlığı araştırmalarından, bir metindeki sözcük, ikileme, deyim ve atasözlerinin tespit edilmesi anlamına gelen "genel amaçla yapılan söz varlığı araştırması" niteliği taşımaktadır. Söz konusu kategoriler belirlenirken Baş’nn (2011) da ifade ettiği gibi belli ölçütler dikkate alınmıştır. Çalışmada sözcük, "taban" olarak ele alınmıştır (Kurudayığlu ve Karadağ). TDK internet sitesindeki sözlüğe ek olarak belli durumlarda günlük kullanımları göz önünde bulundurulan söz varlığı unsurlarının yer yer esnek kabullerle sözcük, ikileme, deyim ve atasözü gruplarında değerlendirildiği söylenebilir. Verilerin analizi sürecinde şu aşamalar izlenmiştir:

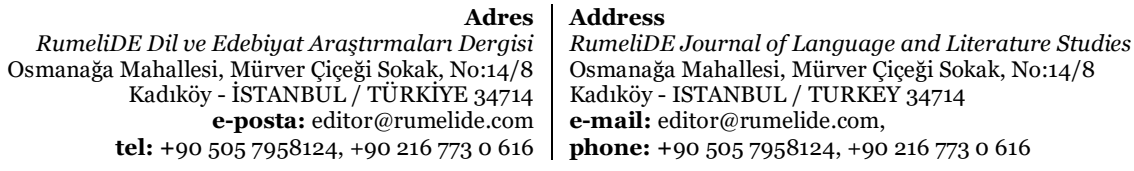


Bilgisayar ortamına aktarılan kitap Word dosyası hâline getirilmiştir.

İnceleme alanına dâhil olmayan fazlalıklar silinmiştir (sayfa numaraları, kitap ismi, alıştırma numaraları, resimler).

Özel isimler metinden silinmiştir.

Kısaltmalar açılmış hâliyle yazılmış, bu ifadeler “+” işaretiyle birleştirilmiştir.

Sayılar yazılı hâle getirilmiş (basamak sayıları), sayıların “+” işaretiyle birleştirilmesi sağlanmıştır.

Tarih ifadeleri “+” işaretiyle birleştirilmiştir.

Sözcüklerden çekim ekleri silinmiştir.

Fiillerden olumsuzluk eki, geçici zarf-fiil, sıfat-fiil yapan ekler silinmiş ve fiillerin sonuna “_“ işaretinin konulmuştur.

Kalıcı isim yapan isim-fiil eki bırakılmıştır.

İsimler ve fiiller basit veya gövde hâlleriyle bırakılmıştır.

Birleşik isimlerin, birleşik fillerin ikilemelerin, deyimlerin, atasözlerinin kalıp olarak ele alınması ve

“+” ile birleştirilmesi sağlanmıştır.

Çok anlamlılık incelenmemiş ancak rastlanan farklı sözcükler belirtilmiştir (çay, hayır vb.).

Düzeltme eki kaldırılmıştır.

"DA" ekinin tek bir biçimi yazılmıştır.

"Mı" soru ekinin tek bir biçimi yazılmıştır.

Hem ... hem gibi bağlaçlar birleştirilmiştir (hem+hem).

CİBAKAYA 2.o programı vasıtasıyla Türkçe Öğrenen Yabancılar için Türk Edebiyatı Antolojisi kitabında yer alan sözcüklerin, deyimlerin, ikilemelerin ve atasözlerinin toplam sayısına ve tekrar etme sayısına dolayısıyla sıklığına ulaşılmıştır. Ardından elde edilen verilerin Microsoft Office Excel programına aktarılması ve "Pivot Table" özelliğinin kullanılmasıyla tablolaştırılması sağlanmıştır.

\section{Bulgular}

\subsection{Incelenen kitapta yer alan toplam ve farklı sözcüklerin, ikilemelerin, deyimlerin ve atasözlerinin sayısına ilişkin bulgular ve yorum}

“Türkçe Öğrenen Yabancılar İçin Türk Edebiyatı Antolojisi”nde yer alan sözcüklerin ikilemelerin, deyimlerin ve atasözlerinin toplam ve farklı kullanım sayısına yönelik bulgular aşă̆ıdaki tabloda sunulmaktadır.

Tablo 2. İncelenen kitaptaki toplam ve farklı sözcüklerin, ikilemelerin, deyimlerin ve atasözlerinin sayısı

\begin{tabular}{|c|c|c|c|}
\hline Grup Türü & Toplam Sayı & Farklı Sayı & $\begin{array}{l}\text { Grup Türünün Katsayısı (Farklı sözcük sayısı / } \\
\text { toplam sözcük sayısı }\end{array}$ \\
\hline Sözcük & 19465 & 3517 & 0,18 \\
\hline İkileme & 158 & 103 & 0,65 \\
\hline Deyim & 363 & 269 & 0,74 \\
\hline Atasözü & 9 & 7 & 0,77 \\
\hline Toplam & 19995 & 3894 & 0,19 \\
\hline
\end{tabular}

Tablo 2'de sunulan verilerden hareketle kitapta 19.995 sözcük/sözcük grubunun incelendiği ve toplam sayının en çok olduğu grubu "sözcük"lerin oluşturduğu görülmektedir. Toplam sayı bağlamında

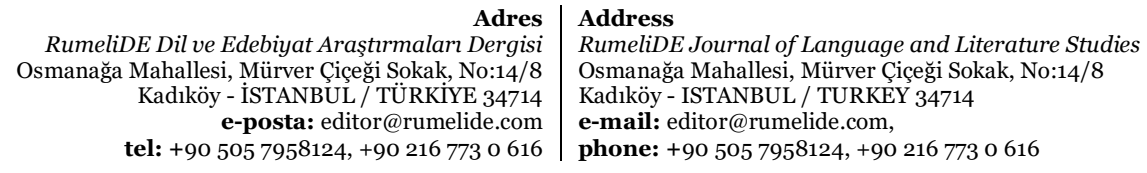


"sözcük”leri sırasıyla; deyim, ikileme ve atasözü takip etmektedir. Günlük dil kullanımında da söz varlı̆̆ı unsurlarından sözcüklerin, diğer söz varlı̆̆ı unsurlarından çok daha yoğun kullanıldığı bilinmektedir. Tablo 2'deki veriler de bu görüşü destekler niteliktedir. Tablo 2'de sunulduğu üzere en az yer verilen sözcük grubunu ise atasözleri oluşturmaktadır. B2-C1 seviyesi tarafından kullanılmak üzere hazırlanmış bu kitapta toplam sözcük sayısına oranla yer verilen atasözü sayısı dikkat çekici derecede az görülmektedir. Grup türlerinin katsayısı incelendiğinde her ne kadar atasözlerinin "farklı sözcük/sözcük grubu sayısı”nın oranı yüksek bulunsa da bunun sebebi atasözü sayısının azlı̆̆ına bağlanabilmektedir.

\section{2. İncelenen kitapta yer alan sözcüklerin hangileri olduğuna ilişkin bulgular ve yorum}

Bu bölümde “Türkçe Öğrenen Yabancılar İçin Türk Edebiyatı Antolojisi”nde hangi sözcüklerin hangi kullanım sıklı̆̆ıyla yer aldığı konusu incelenmiştir. "Sözcük" kategorisinde; isim, sıfat, bağlaç, zarf, edat, ünlem, fiil, zamir ve sık kullanılan birleşik sözcükler ele alınmıştır. "Sözcük" kategorisinde ele alınan bu gruba ilişkin veriler tablolaştırılmıştır. Elde edilen sözcük listesinde yer alan ilk 40 sözcük bu başlık altında sunulurken sözcük listesinin tamamı çalışmanın sonunda Ek 1'de paylaşılmaktadır.

Tablo 3. İncelenen kitapta yer alan ilk 40 sözcük ve ilk 40 sözcügüün sıklık sayıları

\begin{tabular}{llllllll}
\hline Sözcükler & $\begin{array}{l}\text { Sıklık } \\
\text { SayıSı }\end{array}$ & Sözcükler & $\begin{array}{l}\text { S1klık } \\
\text { SayıSı }\end{array}$ & Sözcükler & $\begin{array}{l}\text { Sıklık } \\
\text { Sayısı }\end{array}$ & Sözcükler & $\begin{array}{l}\text { Sıklık } \\
\text { SayıSı }\end{array}$ \\
\hline bir & 771 & gör- & 116 & bak- & 89 & sen & 75 \\
da & 313 & şehzade & 112 & mi & 85 & al- & 75 \\
bu & 294 & gibi & 111 & çocuk & 82 & ama & 74 \\
ol- & 291 & sonra & 110 & her & 82 & insan & 74 \\
ve & 284 & git- & 101 & için & 80 & başla- & 74 \\
o & 263 & var & 99 & yap- & 77 & iste- & 72 \\
de- & 193 & kadar & 98 & ev & 76 & çok & 68 \\
gel- & 163 & ile & 95 & iç & 76 & ver- & 67 \\
ne & 144 & küçük & 92 & iki & 76 & geç- & 66 \\
ben & 138 & gün & 91 & kendi & 76 & zaman & 64 \\
\hline
\end{tabular}

Tablo 3'te sunulan verilere göre; bir, da, bu, ol-, ve, o, de-, gel, ne, ben, gör-, şehzade, gibi, sonra, git-, var, kadar, ile, küçük, gün sözcükleri sıklığı en yüksek olan ilk 20 sözcüğe karşılık gelmektedir. Bu ilk 20 sözcük incelendiğinde 'şehzade' sözcüğü haricindeki sözcüklerin sıklıklarının yüksek çıması beklenmedik bir durum değildir. A1 ve A2 seviyelerinde tamamı kullanılan temel sözcüklerden olan bu sözcükler, sosyal aktör olan dil kullanıcısının ilk öğrendiği sözcüklerdir. B2-C1 seviyesindeki yabancı öğreniciler için hazırlanmış bu kitapta da sıklıklarının yüksek çıkması, özgün metinlerin sıklık anlamında da sosyal hayattaki önem derecesiyle uygun içerikler barındırdığının göstergesi olarak kabul edilebilir. İlk 20 sözcük arasında "şehzade"nin yer alması ise beklenmedik bir durumdur. Günümüzde var olan siyasi yönetim şekli içinde yer almamasına ve dolayısıyla kullanım sahası olmamasına rağmen bu sözcüğün sıklığının yüksek çıkması, kitapta yer alan metinlerden bazılarının halk hikâyesi ve efsanelere dayalı olmasına bağlanabilir.

\section{3. İncelenen kitapta yer alan ikilemelerin hangileri olduğuna ilişkin bulgular ve yorum}

Bu bölümde “Türkçe Öğrenen Yabancılar İçin Türk Edebiyatı Antolojisi”nde hangi ikilemelerin hangi kullanım sıklığıyla yer aldığı konusu incelenmiştir. Elde edilen ikileme listesinde yer alan ilk 40 ikileme

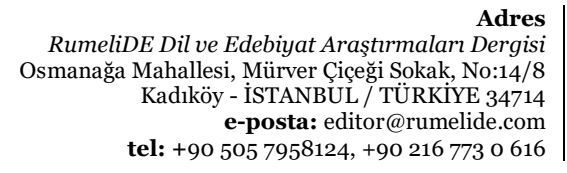

Adres

RumeliDE Journal of Language and Literature Studies

Osmanağa Mahallesi, Mürver Çiçeği Sokak, No:14/8

Kadıköy - ISTANBUL / TURKEY 34714

e-mail: editor@rumelide.com,

phone: +90 $5057958124,+902167730616$ 
bu başlık altında sunulurken ikileme listesinin tamamı çalışmanın sonunda Ek 2'de ekte paylaşılmaktadır.

Tablo 4. İncelenen kitapta yer alan ilk 40 ikileme ve ilk 40 ikilemenin sıklık sayıları

\begin{tabular}{llllllll}
\hline İkilemeler & $\begin{array}{l}\text { Sıklık } \\
\text { Sayısı }\end{array}$ & İkilemeler & $\begin{array}{l}\text { Siklık } \\
\text { Sayısı }\end{array}$ & İkilemeler & $\begin{array}{c}\text { Sıklık } \\
\text { Sayısı }\end{array}$ & íkilemeler & $\begin{array}{c}\text { Sıklık } \\
\text { Sayısı }\end{array}$ \\
\hline ağır ağır & 6 & sık sık & 3 & girer girmez & 2 & ak pak & 1 \\
kendi kendine & 6 & sıkı sıkı & 3 & hızlı hızlı & 2 & arada sırada & 1 \\
yavaş yavaş & 6 & şaşkın şaşkın & 3 & kısa kısa & 2 & ardı sıra & 1 \\
pırıl pırıl & 5 & ufak tefek & 3 & titreye titreye & 2 & bakar bakmaz 1 & 1 \\
ara sıra & 4 & bile bile & 2 & yan yana & 2 & baştan başa & 1 \\
görür görmez & 4 & çoluk çocuk & 2 & yer yer & 2 & biçim biçim & 1 \\
uzun uzun & 4 & çoluklu çocuklu & 2 & yırtık pırtık & 2 & bir bir & 1 \\
birer birer & 3 & derli toplu & 2 & ablak ablak & 1 & bol bol & 1 \\
büyük büyük & 3 & düğün dernek & 2 & acele acele & 1 & boylu poslu & 1 \\
parça parça & 3 & gide gide & 2 & aheste aheste & 1 & büyüte büyüte & 1 \\
\hline
\end{tabular}

Tablo 4’teki verilere göre ağır ağır, hem hem, kendi kendine, yavaş yavaş, pırıl purıl, ara sıra, görür görmez, uzun uzun, birer birer, büyük büyük ikilemeleri slklı̆̆ en yüksek ikilemeler olarak tespit edilmiştir. En sık kullanılan ikilemeler incelendiğinde oluşum şekillerine göre daha çok kendini tekrar eden sözcüklerden oluşan ikilemelere başvurulması dikkat çekmektedir. İncelenen kitaptaki ikileme sayısının fazla olması, kitabın B2-C1 seviyesindeki öğreniciler için hazırlanmış olmasına bağlı olarak değerlendirilebilir. Ayrıca kitaptaki ana okuma metinlerinin özgün metinler olduğu hesaba katıldığında, söz varlığını oluşturan yapılardan biri olan ikilemelerin aktarılmasında kitabın önemli bir işlev üstlendiği söylenebilir. Yabacı'nın (2020) yabancı dil olarak Türkçe öğretimi kitaplarındaki ikilemeleri yapı, işlev ve anlam açısından değerlendirdiği çalışmasından hareketle; Tablo 4’te sunulan ikilemelerin yabancı dil olarak Türkçenin öğretiminde sözcük dağarcığının geliştirilmesi ve kültür aktarımının sağlanması noktasında etki oluşturabilecek nicelikte olduğu söylenebilir.

\section{5. İncelenen kitapta yer alan deyimlerin hangileri olduğuna ilişkin bulgular ve yorum}

Bu bölümde, "Türkçe Öğrenen Yabancılar İçin Türk Edebiyatı Antolojisi” kitabında hangi deyimlerin hangi kullanım sıklığıyla yer aldığına yönelik bulgular tablolaştırılarak yorumlanmıştır. Elde edilen deyim listesinde yer alan ilk 40 deyim bu başlık altında sunulurken ikileme listesinin tamamı çalışmanın sonunda Ek 3’te paylaşılmaktadır.

Tablo 5. İncelenen kitapta yer alan ilk 40 deyim ve ilk 40 deyimin sıklık saylları

\begin{tabular}{|c|c|c|c|c|c|c|c|}
\hline Deyimler & $\begin{array}{l}\text { Siklık } \\
\text { Sayısı }\end{array}$ & Deyimler & $\begin{array}{l}\text { Siklık } \\
\text { Sayısı }\end{array}$ & Deyimler & $\begin{array}{l}\text { Siklık } \\
\text { Sayısı }\end{array}$ & Deyimler & $\begin{array}{l}\text { Siklık } \\
\text { Sayısı }\end{array}$ \\
\hline ortaya çık- & 9 & gönül ver- & 3 & ad ver- & 2 & can ver- & 2 \\
\hline anlamina gel- & 6 & gözden kaybol- & 3 & akla gel- & 2 & cana kıy- & 2 \\
\hline canı sıkıl- & 6 & $\begin{array}{l}\text { hayata gözlerini } \\
\text { yum- }\end{array}$ & 3 & aklına gel- & 2 & denk gel- & 2 \\
\hline & $\begin{array}{r}\text { RumeliDE } D \\
\text { Osmanağa Mah } \\
\text { Kad } \\
\text { tel: }\end{array}$ & $\begin{array}{l}\text { il ve Edebiyat Araşturn } \\
\text { allesi, Mürver Çiçeği S } \\
\text { lköy - İSTANBUL / Tü } \\
\text { e-posta: editor@ } \\
\text { +90 505 7958124, +90 }\end{array}$ & $\begin{array}{r}\text { Adres } \\
\text { ar Dergisi } \\
\mathrm{k}, \text { No:14/8 } \\
\text { KIYE } 34714 \\
\text { melide.com } \\
6773 \text { o } 616\end{array}$ & \multicolumn{4}{|c|}{$\begin{array}{l}\text { Address } \\
\text { RumeliDE Journal of Language and Literature Studies } \\
\text { Osmanağa Mahallesi, Mürver Cicçeği Sokak, No:14/8 } \\
\text { Kadıköy - ISTANBUL / TURKEY } 34714 \\
\text { e-mail: editor@ @rumelide.com, } \\
\text { phone: +90 505 7958124, +90 } 216773 \text { o } 616\end{array}$} \\
\hline
\end{tabular}




\begin{tabular}{|c|c|c|c|c|c|c|c|}
\hline bir bir anlat- & 5 & hoşuna git- & 3 & $\begin{array}{l}\text { allahın emri ile } \\
\text { iste- }\end{array}$ & 2 & göz kamaştır- & 2 \\
\hline dünyaya gel- & 5 & kalbi çarp- & 3 & ayak bas- & 2 & gözlerini dik- & 2 \\
\hline başından geç- & 4 & kaleme al- & 3 & başı sıkıya gir- & 2 & içi clz et- & 2 \\
\hline dikkate al- & 4 & neme lazım & 3 & başına geç- & 2 & içinden geç- & 2 \\
\hline $\begin{array}{l}\text { sudan çımış } \\
\text { balığa dön- }\end{array}$ & 4 & ortadan kaybol- & 3 & başına gel- & 2 & ilgi duy- & 2 \\
\hline yollara düş- & 4 & peşine düş- & 3 & boy ölçüş- & 2 & $\begin{array}{l}\text { ipiyle kuyuya } \\
\text { inilir mi }\end{array}$ & 2 \\
\hline $\begin{array}{l}\text { başımın } \\
\text { üstünde yeri var }\end{array}$ & 3 & ümidi kes- & 3 & boynunu bük- & 2 & kafa tut- & 2 \\
\hline
\end{tabular}

Tablo 5'e göre, Türkçe Öğrenen Yabancılar İçin Türk Edebiyatı Antolojisi’nde deyimlere toplam sayı olarak 363 defa yerilmiştir. Tekrar eden deyimler haricinde 269 farklı deyim kullanılmıştır. En yüksek sıklığa yüksek deyim 9 defa tekrar etmesiyle "ortaya çımak" deyimi olmuştur. Yine anlamına gelmek, canı sıkılmak, bir bir anlatmak, dünyaya gelmek, başından geçmek, dikkate almak, sudan çıkmış bahı̆a dönmek ve yollara düşmek deyimleri sırasıyla en sık kullanılan deyimler olarak belirlenmiştir. "Sözcük" kategorisinden sonra toplam ve farklı sayısı en sözcük grubunun deyimler olması, Türkçenin mecazlı söyleyişlerindeki fazlalığa da işaret etmektedir. İncelenen kitabın B2-C1 seviyesine hitaben hazırlanmış olması da mecazlı söyleyişlerin sayısının yüksek olmasındaki sebeplerden biri olarak gösterilebilir. Doğmak fiili yerine dünyaya gelmek deyiminin kullanılması, "olay" veya "yaşamak" sözcüğü yerine "başından geçmek" deyiminin kullanılması sözcük dağarcığının geliştirilmesi bağlamında önemli bir görev üstlenmektedir.

\subsection{Incelenen kitapta yer alan atasözlerinin hangileri olduğuna ilişkin bulgular ve yorum}

Çalışmanın bu bölümünde, Türkçe Öğrenen Yabancılar İçin Türk Edebiyatı Antolojisi’nde hangi atasözlerinin hangi kullanım sıklı̆̆ıyla yer aldığı konusu ele alınmıştır. "Atasözü” kategorisinde ele alınan bu gruba ilişkin veriler Tablo 6'da sunulmuştur.

Tablo 6. Incelenen kitapta yer alan atasözleri ve sıklık sayıları

\begin{tabular}{ll}
\hline Atasözleri & Sıklık Sayıs \\
\hline İnsan insana benzer & 3 \\
Boynuz kulağı geçer & 1 \\
Davul bile dengi dengine çalar & 1 \\
Garip kuşun yuvasını Allah yapar & 1 \\
Gönül ferman dinlemez & 1 \\
Gün doğmadan neler doğar & 1 \\
Her yiğidin kalbinde bir aslan yatar & 1 \\
\hline
\end{tabular}

Tablo 6’ya göre 19.995 sözcük/sözcük grubundan oluşan kitapta yalnızca 9 atasözüne yer verilmiş ve 7 farklı atasözü tespit edilmiştir. İncelenen kitabın B2-C1 seviyesindeki öğrenicilere sunulmuş olması,

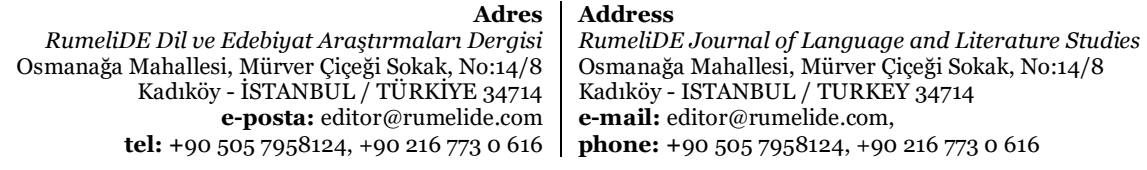


daha fazla atasözüyle karşılaşılacağı fikri oluşturmasına rağmen beklentinin tersi bir bulgu elde edilmiştir. Kitapta atasözlerinin az yer alıyor olması, özgün metinlerden oluşmasına bağlanabilir. Yapay metinlerde seviyeye göre ögeler eklenebilirken özgün metinlerden faydalanıldığında içeriğe müdahale imkânı kısıtlı olabilir.

\section{Tartışma ve sonuç}

Türkçenin yabancı dil olarak öğretiminde, tüm yabancı dillerin öğretiminde ve öğreniminde olduğu gibi sözcük öğretimi konusu önem arz etmektedir. Çeşitli yönleriyle ele alınan sözcük öğretiminde en önemli sorulardan/sorunlardan biri olarak da "Neyi öğreteceğiz?” sorusu kabul edilmektedir (Göçen, 2016; Tüfekçioğlu, 2016; Uzdu Yıldız, 2013). Öğretilecek sözcüklerin seçilmesi, belirlenmesi noktasında alanyazında bir fikir birliği sağlanamamasına bağlı olarak yabancı dil öğretiminin planlanmasında "sözcük öğretimi" standart olmayan bir şekilde gerçekleşmektedir. Bunun sonucu olarak Avrupa Dilleri Ortak Çerçeve Metni’nde (2018) "sosyal aktör" olma özelliği önemle dile getirilen dil kullanıcısının sosyal hayatta ihtiyaç duyacağı sözcükleri, ihtiyaç duyulan ölçüde edinememesi sorunu ile karşılaşılmaktadır. Bu gereklilik durumuna bağlı olarak yabancı dil olarak Türkçenin öğretimi alanında kullanılmak üzere hazırlanan ders kitaplarının, okuma kitaplarının, web platformlarının siklık çalışmalarıyla "söz varlı̆̆ı" bağlamında ele alınması; öğreniciye kazandırılması gereken sözcüklerin tespit edilmesine katkı sağlayacağı düşünülmüştür. Bu çerçevede "Türkçe Öğrenen Yabancılar İçin Türk Edebiyatı Antolojisi” kitabının söz varlı̆̆ı incelenmiştir. Özellikle incelenen kitabın özgün metin içerikli olmasının “Neyi öğreteceğiz?” sorusunun cevaplanmasına katkı sağlayacağı düşünülmektedir.

“Türkçe Öğrenen Yabancılar için Türk Edebiyatı Antolojisi” adlı eserin söz varlığı bağlamında zengin bir niteliğe sahip olduğunu söylemek mümkündür. Alanyazında yabancılara Türkçe öğretimi amacıyla hazırlanan okuma kitaplarının söz varlığı bağlamında incelendiği çalışmalar gerçekleştirilmiştir (Göçen, Karabulut, Yıldız Memiş ve Darama, 2020; Göçen ve Aydın, 2021). Ancak bir karşılaştırmaya gidildiğinde şu tablo görülmektedir: Türkçe Öğrenen Yabancılar için Türk Edebiyatı Antolojisi eserinin söz varlığı unsurları, belli bir seviyede hazırlanmış birkaç kitabın veya birden fazla seviyeye (A1, A2, B1, B2,C1) göre hazırlanmış okuma setlerinin söz varlığı unsurlarından sayısal oran anlamında daha ileri durumdadır. Diğer çalışmalarda ayrı seviyeler bağlamında incelenen okuma kitaplarının sayfa sayısının bu çalışmada incelenen kitaba kıyasla daha düşük olduğu ve dolayısıyla söz varlığı unsurlarının da sayısal anlamda daha az olduğu görülmektedir. İncelenen kitabın ise B2-C1 seviyelerine hitap etmesine bağlı olarak hem tema hem de hacim anlamında daha büyük bir zenginlik barındırdığı söylenebilir.

İncelenen eserde sıklığı en yüksek grubu sözcük kategorisi oluşturmuştur. İsim, sıfat, zamir, zarf, fiil, bağlaç, ünlem görevinde bulunan tüm sözcükler bu kategorinin içinde kabul edilmiştir. Stahl-Nagy (2005'ten akt. Yıldız ve Okur, 2010, s. 762) da okuma materyallerindeki sözcük sıklıklarında ilk olarak yapışkan sözcükler (glue words) olarak adlandırdığı edat, sıfat, zarf, zamir görevlerindeki sözcüklerin kaçınılmaz olarak sıkça kullanıldığını vurgulamaktadır. Yıldız’a (2016, s. 412) göre, iletişimin temel öğesi olan kelimeler hem ana dili öğretiminde hem de yabancı dil öğretiminde temel nokta olarak karşımıza çıkmaktadır. Elde edilen sonuç da bu verilerle örtüşmektedir. Doküman analizi yapılan eserde sıklığı en yüksek grup olarak 'sözcük'lerin belirlenmesi; sözcüklerin birleşiminden oluşan deyim, atasözü ve ikileme gruplarından önce sözcüklere ağırlık verilmesi gerektiğini göstermektedir. Sıklı̆̆ı en yüksek sözcükler ise bir, da, bu, ol-, ve, o, de-, gel, ne, ben, gör-, gibi, sonra, git-, var, kadar, ile, küçük, gün şeklindedir. Türkçenin yabancı dil olarak öğretiminde kullanılan okuma kitaplarının incelendiği benzer çalışmalara bakılırsa sıklığı yüksek olan sözcüklerin bu çalışmada elde edilen sonuçlara paralel olduğu görülebilir (Göçen, 2016; Göçen, Şen ve Duman, 2020).

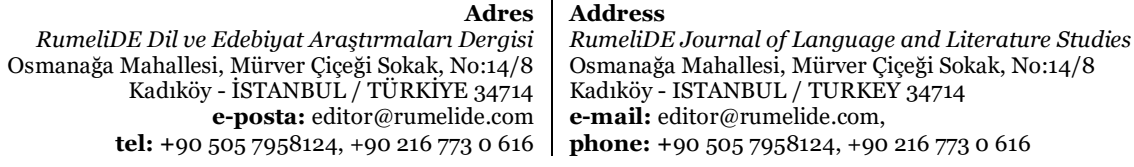


Ayrıca çalışmada, sıklığı yüksek olmamakla birlikte sözcük dağarcığının geliştirilmesine katkı sağlayacak takunya, pençeleşmek, bade içmek, mahzen, külünk, koloni, kerata, kavaf, zifos, aşıboyah, şehadetname, şefaat, koçboynuzu, pir-i ebedi, laden, leylaki, hovarda, hiphop, hilye-i saadet gibi sözcüklerin de yer aldığı görülmüştür. Bu unsurlara yer verilmesi olumlu olarak değerlendirilmektedir. Elde edilen bu veriler Türkçenin yabancı dil olarak öğretiminde kullanılan ders kitaplarındaki söz varlığının ele alındığı çalışmalarla (Göçen, 2016) karşılaştırılırsa "takunya, pençeleşmek, bade içmek, külünk, kerata, kavaf, zifos, aşıboyah, şehadetname, şefaat, koçboynuzu, pir-i ebedi, laden, leylaki, hovarda, hilye-i saadet" sözcüklerinin, hiçbir seviyedeki Türkçe ders kitabı setinde bulunmadığı görülecektir. $\mathrm{Bu}$ da incelenen eserin, ders kitaplarından farklı olarak öğreniciye yeni sözcükler sunabildiğini göstermektedir. Bununla birlikte sosyal hayatta büyük bir yer edinmemesine rağmen sıklığı en yüksek sözcükler arasında çıkan "şehzade" sözcüğünün verileri, kitapta yer alan metinlerin tematik farklılıklarına ve metinlerin farklı uzunluklarda oluşuna bağlanmaktadır.

Çalışmanın bir başka araştırma alanını oluşturan ikilemeler ise sözcük grupları arasında toplam sayı bakımından üçüncü sırada yer almıştır. En sık tekrar eden ikilemelerin başında ağır ağır, kendi kendine, yavaş yavaş, pırl pırıl, ara sıra, görür görmez, uzun uzun, birer birer, büyük büyük ikilemeleri gelmektedir. Bu sonuç da ikilemelerin yabancı dil olarak Türkçe öğretiminde kullanılmasında öncelik verilebilecek ikilemeleri ortaya koymaktadır. Bu bağlamda gerçekleştirilmiş diğer çalışmalara bakıldığında, sıklık düzeyi yüksek olan ikilemeler ile bu çalışmada yüksek sıklıkta olduğu tespit edilen ikilemeler arasında paralellik olduğu görülmektedir (Göçen, 2016; Göçen, Karabulut, Yıldız Memiş ve Darama, 2020). Ayrıca ablak ablak, çalgı çă̆anak gibi ikilemelerin Göçen'in (2016) Yeni Hitit, Gazi, İstanbul yabancılara Türkçe setlerini söz varlığı, sözcük sıklı̆̆ bağlamında ele aldığı çalışmasında bulunmamasına rağmen incelenen kitapta yer aldığı tespit edilmiştir. Bu da geniş yelpazede ikileme türünün kitapta var olduğunu göstermektedir.

“Türkçe Öğrenen Yabancılar İçin Türk Edebiyatı Antolojisi” kitabında söz varlığı ögelerinden biri olan deyimlerin de yüksek oranda yer aldığı görülmektedir. Bunun ise dilin kültür kodunun öğrenici tarafından çözülmesi noktasında etkili olacağı düşünülmektedir. Şenyiğit (2020) de B1 seviyesinden itibaren deyim, ikileme, atasözü gibi anlamsal dil birimlerden yararlanılması gerektiğini ifade etmiştir. Şalvarlı (2010) da deyimleri dilin gücünü arttıran en önemli sözler olarak kabul etmiştir. İncelenen kitabın B2-C1 seviyesine yönelik hazırlandığı göz önünde bulundurulduğunda bu türden kullanımların oranında da artış olması beklenmektedir. Elde edilen bulgular ışığında, eserin bu anlamda zengin bir içeriğe sahip olduğunu söylemek mümkündür. Kitapta en sık kullanılan ilk on deyim sirasiyla ortaya çıkmak, anlamına gelmek, can sıkılmak, bir bir anlatmak, dünyaya gelmek, başından geçmek, dikkate almak, sudan çımış bahğa dönmek ve yollara düşmek, başımın üstünde yeri var deyimleridir. Bir dilin mecaz yapılarını öğrenmek, bu alanda yetkinlik kazanmak ileri düzey bir beceri kabul edildiğinden B2-C1 seviyesindeki Türkçe Öğrenen Yabancılar İçin Türk Edebiyatı Antolojisi kitabında deyimlerin sık yer alması olumlu olarak değerlendirilmektedir. Metinlerin özgün olması, dili yapaylıktan kurtardığından sosyal aktörün ihtiyaç duyması en muhtemel deyimler de bu çalışmayla sıralanmıştır. Ayrıca Göçen, Karabulut, Yıldız Memiş ve Darama’nın (2020) A1, A2, B1, B2 ve C1 seviyelerinde hazırlanmış 8 kitaplık okuma setini söz varlığı ve sözcük sıklığı bağlamında ele aldıkları çalışmada yer almayan "yolundan çevirmek, ciğeri tutuşmak, meydan vermek, gönlünden kopmak, yüreği hop etmek" gibi deyimlerin incelenen eserde yer alıyor olması da eserin bu bağlamda zengin bir içeriğe sahip olduğu görüşünü destekler niteliktedir.

Çalışmanın son araştırma alanı ise kitaptaki atasözlerinin kullanılma durumudur. Yapılan inceleme sonucunda 7’si farklı olmak üzere toplam 9 atasözünün kullanıldı ğı görülmüştür. Bu atasözleri içinde

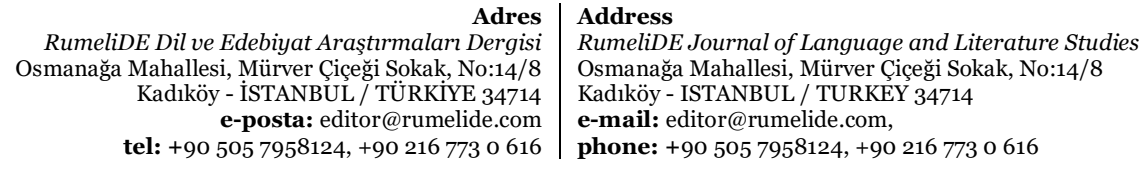


sıklı yönünden ön plana çıkan atasözü ise “İnsan insana benzer.” atasözüdür. Kitapta kullanılan diğer 6 atasözüyle yalnızca bir defa karşılaşılmaktadır. Türkçenin yabancı dil olarak öğretiminde bu atasözlerinin öğretilmesine öncelik verilebilir. Ancak incelenen kitabın atasözleri bağlamında Türkçenin söz varlı̆̆ının zenginliğini yansıtmadığı görülmektedir. Yahşi (2020, s. 22) dil öğretimi sürecinde, Türk kültürünü en iyi yansıtan atasözlerine yer verilmesi gerektiğini belirtmiştir. İncelenen kitabın B2-C1 seviyesine hitap ettiği düşünüldüğünde ve diğer söz varlığı ögelerinin saylları göz önünde bulundurulduğunda 9 atasözü bulunması eksiklik olarak görülmektedir.

Türkçenin yabancı dil olarak öğretiminde kullanılmak üzere hazırlanmış özgün okuma kitabının sözcükler, ikilemeler, deyimler ve atasözleri bağlamında ele alındığı bu çalışmanın, yabancı öğrenicilere öğretilebilecek söz varlığı ögelerini ortaya koyarak alanyazına katkı sunacağı düşünülmektedir.

\section{6. Öneriler}

Bu çalışmada; Türkçenin yabancı dil olarak öğretiminde kullanılan, B2-C1 seviyesi hedef alınarak hazırlanmış “Türkçe Öğrenen Yabancılar için Türk Edebiyatı Antolojisi” isimli eser, söz varlığı ve sözcük sıklı̆̆ bağlamında incelenmiştir. Çalışmanın sonunda sözcük, deyim, ikileme ve deyim olmak üzere 4 kategoride sözcük listeleri oluşturulmuştur. Yapılan çalışmadan hareketle Türkçenin yabancı dil olarak öğretiminde kullanılan hipermetinler, otantik metinler vb. metin türleri söz varlı̆̆ı bağlamında karşılaştırmalı olarak incelenebilir. Araştırılmaya devam edilen yabancılara Türkçe kitaplarına ek olarak teknolojinin gelişmesiyle beraber sayıları artan yabancılara Türkçe öğretimi web platformlarının içeriklerinin de söz varlığı bağlamında incelenmesi önerilmektedir. Türkçenin yabancı dil olarak öğretimi alanında kullanılan basılı yayınların, web platformlarının söz varlığı ve sözcük sıklı̆ bağlamında incelenerek sözcük listelerinin ortaya koyulmasının alanyazına hem uygulamalı hem de teorik anlamda katkı sunacağı düşünülmektedir. Yine belli temalar bağlamında sunulmuş okuma kitapları, Türkçenin yabancı dil olarak öğretiminde kullanılan ders kitaplarıyla söz varlığı bağlamında karşılaştırmalı olarak incelenebilir.

\section{Kaynakça}

Aksan, D. (2008). Türkçeye yansıyan Türk kültürü. Ankara: Bilgi.

Alsarray, M. (2015). Türkçe Ulusal Derlemi'nde yüksek slklıkta kullamılan adların eşdizimlilikleri. Yayımlanmamış yüksek lisans tezi. Yıldırım Beyazıt Üniversitesi, Sosyal Bilimler Enstitüsü, Ankara.

Barın, E. (2004). Yabancllara Türkçe öğretiminde ilkeler. Türkiyat Araştırmaları, l(1), 19-30.

Baş, B. (2011). Söz varlı̆̆ çalışmalarında ölçütler. TÜBAR, XXIX, s. 27-61.

Bilgiç, M. (2016). Batı Avrupa'da iki dilli Türk çocukların yazıl Türkçe kelime sıklkkları: Fransa örneği. Yayımlanmamış yüksek lisans tezi. Sakarya Üniversitesi, Eğitim Bilimleri Enstitüsü, Sakarya.

Büyüköztürk, Ş., Kılıç Çakmak, E., Akgün, Ö. E., Karadeniz, Ş. ve Demirel, F. (2017). Bilimsel araştırma yöntemleri (23. Baski). Ankara: PegemA.

Council of Europe (2018). Common European framework of reference for languages: learning, teaching, assessment companion volumewth new descriptors. https://rm.coe.int/cefrcompanion-volume-with-new-descriptors2018/1680787989 adresinden erişildi.

Dilidüzgün, Ş. (2019). Türkçenin yabancı dil olarak öğretiminde eylem odaklı yaklaşım bağlamında bildirişim durumlarına göre kelime öğretimi. A. Akay Ahmed ve A. Fişekçioğlu (Ed), Dil kullanıcısı bağlamında kuramdan uygulamaya Türkçenin yabancs dil olarak öğretimi. (1. Baskı), (s. 413-445). Ankara: Nobel Akademik.

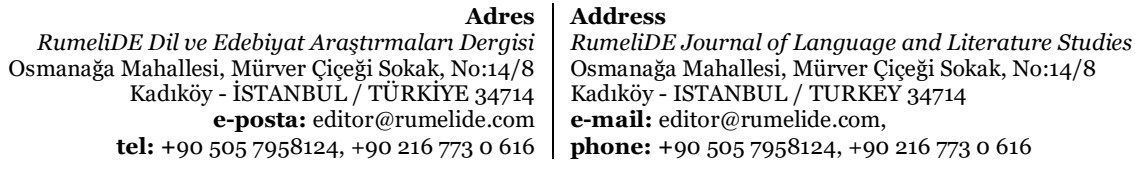


Göçen, G. (2016). Yabancllar için hazırlanan Türkçe ders kitaplartndaki söz varlı̆̆ ile Türkçeyi yabancı dil olarak öğrenenlerin yazılı anlatımlarındaki söz varlı̆̆ı. Yayımlanmamış doktora tezi. Sakarya Üniversitesi, Eğitim Bilimleri Enstitüsü, Sakarya.

Göçen, G., Karabulut, G., Yıldız Memiş, N. ve Darama, M. (2020). Yabancılar için Türkçe okuma kitaplarında yer alan ikileme, deyim ve atasözlerinin kullanım sıklığı ve seviyelere göre dağılımı. International Journal of Languages' Education and Teaching, 8(2), 112-142.

Göçen, G. ve Okur, A. (2019). Türkçenin yabancı dil olarak öğretimi ve sözcük öğretimi. A. Okur ve G. Göçen (Ed), Türkçenin sözcük öğretimi. (1. Baskı), s. 249-272. Ankara: Nobel.

Göçen, G., Şen, B. ve Duman, S. (2020). Yabancılar için Türkçe okuma kitaplarındaki isim soylu kelimelerin kullanım sıklığı. TÜRÜK Uluslararası Dil, Edebiyat ve Halkbilimi Araştırmaları Dergisi, 21, 46-73.

Göçen, G. ve Aydın, E. (2021). Yabancılar için hazırlanmış Türkçe okuma kitaplarındaki söz varlığı: çocuk hikâyeleri dizisi a1-a2 örneği. Uluslararası Yabancı Dil Olarak Türkçe Öğretimi Dergisi, 4(1), 93-126.

Kılıç, T. (2017). Yedi İklim Türkçe ve İstanbul Yabancılar için Türkçe Öğretim setlerindeki fiilimsilerin kullanım sıklığının belirlenmesi. Yayımlanmamış yüksek lisans tezi. Nevşehir Hacı Bektaş Veli Üniversitesi, Sosyal Bilimler Enstitüsü, Nevşehir.

Kurudayıŏ̆lu, M. ve Karadağ, Ö. (2005). Kelime hazinesi çalışmaları açısından kelime kavramı üzerine bir değerlendirme. Gazi Eğitim Fakültesi Dergisi, 25(2), 293-307.

Mete, F. (2014). Kültürel ortaklı̆̆ın göstergesi deyimlerin öğretimi. Ankara Üniversitesi Dil ve TarihCoğrafya Fakültesi Türkoloji Dergisi, 21, (2), 113-128.

Siyanova-Chanturia, A \& Webb, S. (2016). Teaching vocabulary in the EFL context, English Language Teaching Today, 5, 227-239.

https://link.springer.com/chapter/10.1007/978-3-319-38834-2_16 adresinden erişildi.

Şalvarlı, B. (2010). Türkçe deyim öğretimi için metin hazırlama. Yayımlanmamış yüksek lisans tezi, Çanakkale Onsekiz Mart Üniversitesi, Sosyal Bilimler Enstitüsü.

Şenyiğit, Y. (2020). Yabancılara Türkçe öğretiminde sözlü dilin kelime sıklı̆̆ ve a1-a2 seviye sözlüğü. Yayımlanmamış yüksek lisans tezi. Sakarya Üniversitesi, Eğitim Bilimleri Enstitüsü, Sakarya.

Tüfekçioğlu, B. (2016). Yabancı dil olarak Türkçe öğretiminde sözcük öğretimi. Yıldırım, F. Ve Tüfekçioğlu, B. (Ed.), Yabancı dil olarak Türkçe öğretimi: kuramlar - yöntemler - beceriler uygulamalar. (1.Baskı), 267- 288.

Tüm, G. (2010). Atasözlerinin değişik kültür ve dilleri anlamadaki rolü. Turkish Studies - International Periodical For The Languages, Literature and History of Turkish or Turkic, 5 (4), 663- 678.

Türk Dil Kurumu. (2011). Türkçe sözlük. (11.Baskı). Ankara: TDK.

Uzdu Yıldız, F. (2013). Sözcük ve sözcük öğretimi. M. Durmuş ve A. Okur (Ed.), Yabancılara Türkçe öğretimi el kitabı. (1. Baskı), s. 357-364. Ankara: Grafiker.

Vardar, B. (2002). Açılamah dilbilim terimleri sözlüğü. İstanbul: Multilingual.

Yabacı, L. N. (2020). Yabancı dil olarak Türkçe öğretimi kitaplarında ikilemelerin yapı, işlev ve anlam açısından değerlendirilmesi. Yayımlanmamış yüksek lisans tezi. Hacettepe Üniversitesi, Türkiyat Araştırmaları Enstitüsü, Ankara.

Yahşi, Ö. (2020). Yabancılara Türkçe öğretiminde temel düzey söz varlı̆̆ın belirleme: yabancılar için hazırlanan Türkçe ders kitapları ile Türkçeyi yabancı dil olarak öğrenenlerin yazılı ve sözlü anlatım uygulamalarına dayah söz varlı̆g. Yayımlanmamış yüksek lisans tezi. Sakarya Üniversitesi, Eğitim Bilimleri Enstitüsü, Sakarya.

Yıldırım, A. ve Şimşek, H. (2016). Sosyal bilimlerde nitel araştırma yöntemleri. Ankara: Seçkin.

Yıldız, C. ve Okur, A. (2010). İlköğretim okullarındaki okuma etkinliklerinde göz ardı edilen bir konu: sözcük öğretimi. TÜBAR, S. XXVII, s. 753-773.

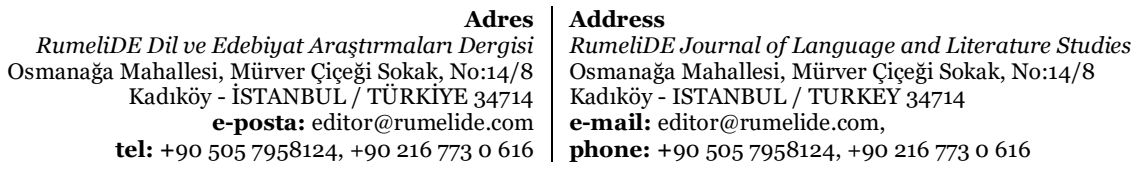


Yıldız, D. (2016). Türkçe öğretmeni adaylarının hazırlıklı konuşmalarındaki söz varlıkları. Millî Eğitim Dergisi, 210, 411-424.

\section{Ekler}

Ek 1. İncelenen kitapta yer alan sözcükler ve sıklık sayıları

\begin{tabular}{|c|c|c|c|c|c|c|c|}
\hline Sözcükler & $\begin{array}{l}\text { Siklık } \\
\text { Sayısı }\end{array}$ & Sözcükler & $\begin{array}{l}\text { Sılklık } \\
\text { Sayısı }\end{array}$ & Sözcükler & $\begin{array}{l}\text { Sıklık } \\
\text { Sayısı }\end{array}$ & Sözcükler & $\begin{array}{l}\text { Siklık } \\
\text { Sayısı }\end{array}$ \\
\hline Bir & 771 & razı ol- & 4 & allahtan & 1 & parıltısız & 1 \\
\hline $\mathrm{Da}$ & 313 & sakla- & 4 & alt kat & 1 & park & 1 \\
\hline bu & 294 & selam ver- & 4 & $\begin{array}{l}\text { altı yüz altmış } \\
\text { yedi }\end{array}$ & 1 & pastane & 1 \\
\hline ol- & 291 & sıkıl- & 4 & altmış & 1 & pazarlık & 1 \\
\hline ve & 284 & sok- & 4 & ambar & 1 & pehlivanlık & 1 \\
\hline o & 263 & şaşır- & 4 & ana dil & 1 & pekala & 1 \\
\hline de- & 193 & tirman- & 4 & ana dili & 1 & perçem & 1 \\
\hline gel- & 163 & uğra- & 4 & anlaşmazlık & 1 & perçemli & 1 \\
\hline ne & 144 & uyan- & 4 & anlayışsız & 1 & perde & 1 \\
\hline ben & 138 & yapış- & 4 & anti tez & 1 & peri kızı & 1 \\
\hline gör- & 116 & yazdır- & 4 & aptalca & 1 & peri masalı & 1 \\
\hline şehzade & 112 & yer al- & 4 & ar & 1 & perişan & 1 \\
\hline gibi & 111 & acaba & 3 & arabacı & 1 & peşinen & 1 \\
\hline sonra & 110 & ada & 3 & arada bir & 1 & peygamber & 1 \\
\hline git- & 101 & ağır & 3 & aralıksız & 1 & peymane & 1 \\
\hline var & 99 & akademisyen & 3 & araştırmacı & 1 & pinar & 1 \\
\hline kadar & 98 & akraba & 3 & arı & 1 & pirıltı & 1 \\
\hline ile & 95 & ameliyat & 3 & arka arkaya & 1 & pilav & 1 \\
\hline küçük & 92 & ansizin & 3 & arkadaşlık & 1 & pilavlık & 1 \\
\hline gün & 91 & apartman & 3 & armağan & 1 & pir & 1 \\
\hline bak- & 89 & assll & 3 & $\operatorname{arsiz}$ & 1 & pir i ebedi & 1 \\
\hline $\mathrm{mi}$ & 85 & asla & 3 & arşiv & 1 & pislik & 1 \\
\hline çocuk & 82 & aslında & 3 & arzuhalci & 1 & piyano & 1 \\
\hline her & 82 & avlu & 3 & asır & 1 & piyasa & 1 \\
\hline için & 80 & aylık & 3 & asker kaçağı & 1 & plan & 1 \\
\hline yap- & 77 & benzerlik & 3 & aslen & 1 & porselen & 1 \\
\hline ev & 76 & benzin & 3 & asma & 1 & portakal & 1 \\
\hline iç & 76 & biçak & 3 & aşağılayıcı & 1 & pos & 1 \\
\hline iki & 76 & bilek & 3 & aşama & 1 & pöh & 1 \\
\hline kendi & 76 & bilgi & 3 & aşıboyalı & 1 & program & 1 \\
\hline sen & 75 & birtakım & 3 & aşık badesi & 1 & programcılık & 1 \\
\hline al- & 75 & boylu & 3 & aşıklık & 1 & pul & 1 \\
\hline ama & 74 & büsbütün & 3 & aşk şerbeti & 1 & pür & 1 \\
\hline & $\begin{array}{r}\text { Rumeli } \\
\text { Osmanağa }\end{array}$ & $\begin{array}{r}\text { E Dil ve Edebiyat A } \\
\text { lahallesi, Mürver C } \\
\text { Kadıköy - İSTANBL } \\
\text { e-posta: e } \\
\text { l: +90 } 505795812\end{array}$ & $\begin{array}{l}\text { irmalar } D \\
\text { i Sokak, N } \\
\text { TÜRKIYE } \\
\text { r@rumelid } \\
90216773\end{array}$ & $\begin{array}{l}\text { Address } \\
\text { RumeliDE } J \\
\text { Osmanağa N } \\
\text { Kadıköy - IS } \\
\text { e-mail: edit } \\
\text { phone: }+90\end{array}$ & $\begin{array}{l}\text { l of Languc } \\
\text { lesi, Mürver } \\
\text { 3UL / TURI } \\
\text { umelide.co } \\
\text { 7958124, + }\end{array}$ & $\begin{array}{l}\text { and Literature Studies } \\
\text { eği Sokak, No:14/8 } \\
34714 \\
16773 \text { o } 616\end{array}$ & \\
\hline
\end{tabular}


Türkçenin yabancı dil olarak öğretiminde kullanılan okuma kitaplarındaki söz varlığı ögelerinin incelenmesi / M. Göker; G.

\begin{tabular}{|c|c|c|c|c|c|c|c|}
\hline insan & 74 & ceket & 3 & \multicolumn{2}{|c|}{ atak } & 1 & raf \\
\hline başla- & 74 & ceza & 3 & \multicolumn{2}{|c|}{ atasözü } & 1 & rahat \\
\hline iste- & 72 & çalı & 3 & \multicolumn{2}{|c|}{ atmaca } & 1 & $\begin{array}{l}\text { ramazan } \\
\text { davulcusu }\end{array}$ \\
\hline çok & 68 & çamlık & 3 & \multicolumn{2}{|c|}{ atmosfer } & 1 & rastlantı \\
\hline ver- & 67 & çardak & 3 & \multicolumn{2}{|c|}{ avrupalı } & 1 & reçel \\
\hline geç- & 66 & çarşaf & 3 & \multicolumn{2}{|c|}{ ayaklı } & 1 & renkli \\
\hline zaman & 64 & çatal & 3 & \multicolumn{2}{|c|}{ aydınlan- } & 1 & resmen \\
\hline daha & 62 & çayır & 3 & \multicolumn{2}{|c|}{ ayet } & 1 & rihtım \\
\hline diye & 62 & çı̆̆ırtkan & 3 & \multicolumn{2}{|c|}{ ayna } & 1 & ritim \\
\hline $\mathrm{klz}$ & 61 & çift & 3 & \multicolumn{2}{|c|}{ aynen } & 1 & rivayet \\
\hline şey & 61 & çoban & 3 & \multicolumn{2}{|c|}{ ayol } & 1 & röportaj \\
\hline ki & 60 & çuval & 3 & \multicolumn{2}{|c|}{ ayva } & 1 & sabaha karşı \\
\hline baş & 59 & dağıtımcı & 3 & \multicolumn{2}{|c|}{ ayvaz } & 1 & sabırsızlık \\
\hline el & 59 & damla & 3 & \multicolumn{2}{|c|}{ azap } & 1 & sabit \\
\hline yer & 58 & damlacık & 3 & \multicolumn{2}{|c|}{ babaanne } & 1 & sadakat \\
\hline yll & 58 & darı & 3 & \multicolumn{2}{|c|}{ babacan } & 1 & sadık \\
\hline çlk- & 58 & davranış & 3 & \multicolumn{2}{|c|}{ bacak } & 1 & saflık \\
\hline Büyük & 57 & davul & 3 & \multicolumn{2}{|c|}{ bacaklı } & 1 & sağanak \\
\hline Çiçek & 57 & defter & 3 & \multicolumn{2}{|c|}{ bade } & 1 & sağlam \\
\hline En & 56 & delik & 3 & \multicolumn{2}{|c|}{ badem } & 1 & sağllk \\
\hline yaz- & 55 & demir & 3 & \multicolumn{2}{|c|}{ badem ezmesi } & 1 & sahil \\
\hline Adam & 53 & deneme & 3 & \multicolumn{2}{|c|}{ bağ } & 1 & sahne \\
\hline söyle- & 52 & derhal & 3 & \multicolumn{2}{|c|}{ bağlam } & 1 & saklı \\
\hline Anne & 50 & derinlik & 3 & \multicolumn{2}{|c|}{ bağlantı } & 1 & sako \\
\hline Üzeri & 50 & dilek & 3 & \multicolumn{2}{|c|}{ bahçıvan } & 1 & salata \\
\hline kal- & 50 & doğruca & 3 & bah & & 1 & salon \\
\hline Bura & 48 & durgun & 3 & bak & ımsızlık & 1 & saltanat \\
\hline Fakat & 48 & durmadan & 3 & bak & IŞ açıSı & 1 & samimiyet \\
\hline Metin & 48 & efsane & 3 & bak & kal & 1 & sandal \\
\hline oku- & 48 & ekmek & 3 & bal & & 1 & sandalye \\
\hline Ara & 47 & eksik & 3 & balı & kçı & 1 & saplı \\
\hline Yan & 47 & entari & 3 & ban & & 1 & sapsiz \\
\hline Baba & 46 & epey & 3 & barı & & 1 & sarhoş \\
\hline $\mathrm{Siz}$ & 46 & epeyce & 3 & bası & & 1 & sarıklık \\
\hline Aşağl & 45 & evlat & 3 & bası & ma & 1 & sarışın \\
\hline Gece & 45 & ezan & 3 & bası & macı & 1 & sarnıç \\
\hline Hayat & 44 & facia & 3 & başa & & 1 & satıcılık \\
\hline Kadın & 43 & falan & 3 & başl & kent & 1 & satırlık \\
\hline Nasıl & 43 & fisiltı & 3 & başl & & 1 & satış noktası \\
\hline & $\begin{array}{r}R u \\
\text { Osma }\end{array}$ & $\begin{array}{r}\text { E Dil ve Edebiy } \\
\text { Mahallesi, Mürv } \\
\text { Kadıköy - İSTA } \\
\text { e-post } \\
\text { el: +90 } 505795\end{array}$ & Ti So & $\begin{array}{l}\text { Ires } \\
\text { rgisi } \\
14 / 8 \\
4714 \\
\text { com } \\
616\end{array}$ & $\begin{array}{l}\text { Address } \\
\text { RumeliDE Jou } \\
\text { Osmanağa Ma } \\
\text { Kadıköy- ISTA } \\
\text { e-mail: editor } \\
\text { phone: +90 } 5\end{array}$ & um & $\begin{array}{l}\text { and Literature Studies } \\
\text { eği Sokak, No:14/8 } \\
34714 \\
16773 \text { o } 616\end{array}$ \\
\hline
\end{tabular}


Examination of vocabulary items in reading books used in teaching Turkish as a foreign language / M. Göker; G. Göçen (pp. 407-446)

\begin{tabular}{|c|c|c|c|c|c|c|c|}
\hline Ora & 43 & fincan & 3 & \multicolumn{2}{|c|}{ batı } & 1 & savunucu \\
\hline otur- & 43 & galiba & 3 & \multicolumn{2}{|c|}{ batıl } & 1 & sayg1 \\
\hline Göz & 42 & gazetecilik & 3 & \multicolumn{2}{|c|}{ batıl inanç } & 1 & seçenek \\
\hline Hemen & 42 & geç & 3 & \multicolumn{2}{|c|}{ bayağı } & 1 & seher \\
\hline Ses & 42 & geçen & 3 & \multicolumn{2}{|c|}{ bayrak } & 1 & sekiz bin beş yüz \\
\hline anlat- & 42 & genellikle & 3 & \multicolumn{2}{|c|}{ bayram } & 1 & sekiz dokuz \\
\hline bil- & 42 & gerçekten & 3 & \multicolumn{2}{|c|}{ bayramlık } & 1 & sekizinci \\
\hline dur- & 41 & gerekli & 3 & \multicolumn{2}{|c|}{ bel } & 1 & selamlık \\
\hline sor- & 41 & gezi & 3 & \multicolumn{2}{|c|}{ belirgin } & 1 & selvi \\
\hline Bütün & 40 & gittikçe & 3 & \multicolumn{2}{|c|}{ bembeyaz } & 1 & sembol \\
\hline İş & 40 & göçmen & 3 & \multicolumn{2}{|c|}{ bence } & 1 & sensiz \\
\hline Değil & 39 & gök & 3 & \multicolumn{2}{|c|}{ beneksiz } & 1 & sergi \\
\hline gir- & 39 & gözlü & 3 & \multicolumn{2}{|c|}{ benli } & 1 & serili \\
\hline $\mathrm{Biz}$ & 38 & gözyaşı & 3 & \multicolumn{2}{|c|}{ benlik } & 1 & serin \\
\hline Dev & 38 & güç & 3 & \multicolumn{2}{|c|}{ berber } & 1 & serinlik \\
\hline Üç & 38 & günlük & 3 & \multicolumn{2}{|c|}{ berhane } & 1 & sermaye \\
\hline Ümit & 38 & güya & 3 & \multicolumn{2}{|c|}{ besbelli } & 1 & serüven \\
\hline Beş & 37 & ha & 3 & \multicolumn{2}{|c|}{ beş yüz bin } & 1 & sevdalı \\
\hline Yazar & 37 & hafif & 3 & \multicolumn{2}{|c|}{ beyefendi } & 1 & sevimli \\
\hline Yine & 37 & hakkında & 3 & \multicolumn{2}{|c|}{ beyit } & 1 & sevimsiz \\
\hline bul- & 37 & hasir & 3 & \multicolumn{2}{|c|}{ bez } & 1 & seviye \\
\hline başka & 36 & hasta & 3 & \multicolumn{2}{|c|}{ bilgiç } & 1 & seyir \\
\hline hikaye & 36 & hata & 3 & \multicolumn{2}{|c|}{ bilgili } & 1 & seyirci \\
\hline düşün- & 36 & hayal kırıklığı & 3 & \multicolumn{2}{|c|}{ bilimsel } & 1 & sezgi \\
\hline doğru & 35 & haydi & 3 & \multicolumn{2}{|c|}{$\begin{array}{l}\text { bin altı yüz on } \\
\text { bir }\end{array}$} & 1 & sıcaklık \\
\hline eser & 35 & hedef & 3 & \multicolumn{2}{|c|}{ bin bir güçlük } & 1 & sifat \\
\hline gazete & 35 & herif & 3 & \multicolumn{2}{|c|}{$\begin{array}{l}\text { bin dokuz kırk } \\
\text { yedi }\end{array}$} & 1 & sifir \\
\hline ise & 35 & hücum & 3 & \multicolumn{2}{|c|}{$\begin{array}{l}\text { bin dokuz yüz } \\
\text { altmış dokuz }\end{array}$} & 1 & sik \\
\hline dön- & 35 & israr & 3 & $\begin{array}{l}\text { bin } \\
\text { altn }\end{array}$ & $\begin{array}{l}\text { dokuz yüz } \\
\text { nış iki }\end{array}$ & 1 & sıkıntılı \\
\hline dünya & 34 & ISS1Z & 3 & $\begin{array}{l}\text { bin } \\
\text { altn }\end{array}$ & $\begin{array}{l}\text { dokuz yüz } \\
\text { nış sekiz }\end{array}$ & 1 & sinifsal \\
\hline hangi & 34 & iç dünya & 3 & $\begin{array}{l}\text { bin } \\
\text { altn }\end{array}$ & $\begin{array}{l}\text { dokuz yüz } \\
\text { nış üç }\end{array}$ & 1 & sizılı \\
\hline hiç & 34 & ilim & 3 & bin & dokuz yüz bir & 1 & sızıntı \\
\hline şimdi & 34 & in & 3 & $\begin{array}{l}\text { bin } \\
\text { dok }\end{array}$ & $\begin{array}{l}\text { dokuz yüz } \\
\text { san }\end{array}$ & 1 & sihirbazlık \\
\hline & $\begin{array}{r}R u \\
\text { Osma }\end{array}$ & $\begin{array}{l}\text { E Dil ve Edebiyat Arc } \\
\text { Mahallesi, Mürver Cic } \\
\text { Kadıöy - İSTANBUI } \\
\text { e-posta: ed } \\
\text { el: +90 505 7958124 }\end{array}$ & & & $\begin{array}{l}\text { Address } \\
\text { RumeliDE Journo } \\
\text { Osmanağa Mahall } \\
\text { Kadıköy - ISTANE } \\
\text { e-mail: editor@r } \\
\text { phone: +90 505 }\end{array}$ & $\begin{array}{l}\text { lesi, } \\
\text { luL } \\
\text { um } \\
795\end{array}$ & $\begin{array}{l}\text { and Literature Studies } \\
\text { eği Sokak, No:14/8 } \\
34714 \\
216773 \text { o } 616\end{array}$ \\
\hline
\end{tabular}


Türkçenin yabancı dil olarak öğretiminde kullanılan okuma kitaplarındaki söz varlığı ögelerinin incelenmesi / M. Göker; G.

\begin{tabular}{|c|c|c|c|c|c|c|}
\hline göre & 33 & incir & $\begin{array}{ll}\text { bi } \\
\text { do }\end{array}$ & $\begin{array}{l}\text { bin dokuz yüz } \\
\text { doksan altı }\end{array}$ & 1 & simit \\
\hline ön & 33 & isimli & $\begin{array}{l}\text { bi } \\
\text { ell }\end{array}$ & $\begin{array}{l}\text { bin dokuz yüz } \\
\text { elli iki }\end{array}$ & 1 & simli \\
\hline su & 33 & istasyon & $\begin{array}{l}\text { bi } \\
\text { ell }\end{array}$ & $\begin{array}{l}\text { bin dokuz yüz } \\
\text { elli sekiz }\end{array}$ & 1 & sinek \\
\hline şehir & 33 & $\mathrm{iz}$ & $\begin{array}{l}\text { bi } \\
\text { ell }\end{array}$ & bin dokuz yüz & 1 & sinema \\
\hline ye- & 33 & kabiliyet & $\begin{array}{l}\text { bi } \\
\text { ell }\end{array}$ & bin dokuz yüz & 1 & sivri \\
\hline kapı & 32 & kalın & $\begin{array}{l}\mathrm{bi} \\
\mathrm{k} 1\end{array}$ & bin dokuz yüz & 1 & siyasetçi \\
\hline çalış- & 32 & kanlı & $\begin{array}{l}\mathrm{bi} \\
\mathrm{kl}\end{array}$ & bin dokuz yüz & 1 & siyasi \\
\hline arkadaş & 31 & karakter & $\begin{array}{l}\text { bi } \\
\text { üc }\end{array}$ & \multicolumn{2}{|l|}{ bin dokuz yüz on } & soba \\
\hline böyle & 31 & karınca & $\begin{array}{l}\text { bi } \\
\text { ot }\end{array}$ & bin dokuz yüz & 1 & sokak başı \\
\hline saray & 31 & karyola & $\begin{array}{l}\text { bi } \\
\text { ot }\end{array}$ & $\begin{array}{l}\text { bin dokuz yüz } \\
\text { otuz bir }\end{array}$ & 1 & sokak kapısı \\
\hline kuş & 30 & katip & $\begin{array}{l}\text { bi } \\
\text { ot }\end{array}$ & $\begin{array}{l}\text { bin dokuz yüz } \\
\text { otuz dokuz }\end{array}$ & 1 & solgun \\
\hline taraf & 30 & kaynak & $\begin{array}{l}\text { bi } \\
\text { ot }\end{array}$ & $\begin{array}{l}\text { bin dokuz yüz } \\
\text { otuz dört }\end{array}$ & 1 & sonuç bölümü \\
\hline son & 29 & kelebek & $\begin{array}{l}\mathrm{bi} \\
\mathrm{se}\end{array}$ & $\begin{array}{l}\text { bin dokuz yüz } \\
\text { seksen dokuz }\end{array}$ & 1 & sorumluluk \\
\hline yüz & 29 & kemik & $\begin{array}{l}\mathrm{bi} \\
\mathrm{se}\end{array}$ & $\begin{array}{l}\text { bin dokuz yüz } \\
\text { seksen sekiz }\end{array}$ & 1 & sökük \\
\hline çlkar- & 29 & kent & $\begin{array}{l}\text { bi } \\
\text { ye }\end{array}$ & $\begin{array}{l}\text { bin dokuz yüz } \\
\text { yedi }\end{array}$ & 1 & sönük \\
\hline yürü- & 29 & kıl & $\begin{array}{l}\text { bi } \\
\text { yi }\end{array}$ & $\begin{array}{l}\text { bin dokuz yüz } \\
\text { yirmi altı }\end{array}$ & 1 & söylem \\
\hline arka & 28 & kıyı & $\begin{array}{l}\text { bi } \\
\text { yi }\end{array}$ & $\begin{array}{l}\text { bin dokuz yüz } \\
\text { yirmi dokuz }\end{array}$ & 1 & söylenti \\
\hline mektup & 28 & kimi & $\begin{array}{l}\text { bi } \\
\text { yi }\end{array}$ & $\begin{array}{l}\text { bin dokuz yüz } \\
\text { yirmi sekiz }\end{array}$ & 1 & söz gelimi \\
\hline oda & 28 & koçboynuzu & 3 & bin iki yüz yedi & 1 & sözde \\
\hline yukarı & 28 & kokulu & $\begin{array}{l}\mathrm{bi} \\
\mathrm{ye}\end{array}$ & $\begin{array}{l}\text { bin iki yüz } \\
\text { yetmiş üç }\end{array}$ & 1 & sözler \\
\hline $\operatorname{artık}$ & 27 & kontrat & $\begin{array}{l}\text { bi } \\
\text { al }\end{array}$ & bin sekiz yüz elli & 1 & spor \\
\hline güzel & 27 & korku & $\begin{array}{l}\text { bi } \\
\text { se }\end{array}$ & bin sekiz yüz & 1 & su bardağı \\
\hline üst & 27 & koyu & 3 & bin seksen & 1 & sultan \\
\hline & $\begin{array}{r}R u \\
\text { Osma }\end{array}$ & $\begin{array}{l}\text { E Dil ve Edebiyat } \\
\text { Mahallesi, Mürver } \\
\text { Kadı̈öy - İSTANE } \\
\text { e-posta: } \\
\text { el: +90 } 50579581\end{array}$ & $\begin{array}{r}\text { Adres } \\
\text { trmaları Dergisi } \\
\text { i Sokak, No:14/8 } \\
\text { TÜRKIYE } 34714 \\
\text { r@rumelide.com } \\
902167730616\end{array}$ & \begin{tabular}{l|l}
$\mathbf{s}$ & Address \\
$i$ & RumeliDE Journo \\
8 & Osmanağa Mahal \\
4 & Kadıköy - ISTAN \\
n & e-mail: editor@r r \\
6 & phone: +90 505
\end{tabular} & \begin{tabular}{l|l}
14 & Kadıköy - ISTANBUL / TURKEY 34714 \\
m & e-mail: editor@rumelide.com, \\
16 & phone: +90 505 7958124, +90 216773 o 616
\end{tabular} & $\begin{array}{l}\text { and Literature Studies } \\
\text { eği Sokak, No:14/8 } \\
34714 \\
16773 \text { o } 616\end{array}$ \\
\hline
\end{tabular}


Examination of vocabulary items in reading books used in teaching Turkish as a foreign language / M. Göker; G. Göçen (pp. 407-446)

\begin{tabular}{|c|c|c|c|c|c|c|c|}
\hline koş- & 27 & köy & 3 & \multicolumn{2}{|c|}{ binbir } & 1 & suret \\
\hline bahçe & 26 & kulübe & 3 & \multicolumn{2}{|c|}{ binlerce } & 1 & susuz \\
\hline bile & 26 & kurt & 3 & \multicolumn{2}{|c|}{ bir (aynı) } & 1 & sükun \\
\hline biraz & 26 & kuyu & 3 & \multicolumn{2}{|c|}{ bir başına } & 1 & sükunet \\
\hline sokak & 26 & küçücük & 3 & \multicolumn{2}{|c|}{ bir türlü } & 1 & sünger \\
\hline şiir & 26 & kültür & 3 & \multicolumn{2}{|c|}{ birey } & 1 & sürece \\
\hline aç- & 26 & laf & 3 & \multicolumn{2}{|c|}{ bireycilik } & 1 & süs \\
\hline anla- & 26 & lazım & 3 & \multicolumn{2}{|c|}{ bireysel } & 1 & süslü \\
\hline unut- & 26 & leke & 3 & \multicolumn{2}{|c|}{ biricik } & 1 & sütnine \\
\hline alt & 25 & macera & 3 & \multicolumn{2}{|c|}{ bitki } & 1 & sütun \\
\hline köşk & 25 & mademki & 3 & \multicolumn{2}{|c|}{ bitki örtüsü } & 1 & şairlik \\
\hline onlar & 25 & makale & 3 & \multicolumn{2}{|c|}{ bitkin } & 1 & şaka \\
\hline öyle & 25 & merak & 3 & \multicolumn{2}{|c|}{ bodur } & 1 & şakak \\
\hline soru & 25 & mermi & 3 & \multicolumn{2}{|c|}{ boğaz } & 1 & şam hırkası \\
\hline yol & 25 & meydan & 3 & \multicolumn{2}{|c|}{ boğazına düşkün } & 1 & şans \\
\hline birak- & 25 & meyve & 3 & \multicolumn{2}{|c|}{ boğum } & 1 & Şaşı \\
\hline yaşa- & 25 & motor & 3 & \multicolumn{2}{|c|}{ bohça } & 1 & şef \\
\hline ad & 24 & mutfak & 3 & \multicolumn{2}{|c|}{ bol } & 1 & şefaat \\
\hline ağaç & 24 & mutlaka & 3 & \multicolumn{2}{|c|}{ boncuk } & 1 & şehadetname \\
\hline hal & 24 & mutlu & 3 & \multicolumn{2}{|c|}{ boş yere } & 1 & şemsiyecik \\
\hline karşı & 24 & müddet & 3 & \multicolumn{2}{|c|}{ boşboğaz } & 1 & şenlik \\
\hline konuş- & 24 & nokta & 3 & \multicolumn{2}{|c|}{ boyalı } & 1 & şerbet \\
\hline at & 23 & okuma yazma & 3 & \multicolumn{2}{|c|}{ boylamasina } & 1 & şevk \\
\hline köşe & 23 & on beş & 3 & \multicolumn{2}{|c|}{ boyun bağı } & 1 & şifa \\
\hline oğul & 23 & on iki & 3 & \multicolumn{2}{|c|}{ boyun bağlı } & 1 & şimşek \\
\hline söz & 23 & oracık & 3 & boy & runa & 1 & şirin \\
\hline getir- & 23 & ortaokul & 3 & boz & & 1 & şişmanca \\
\hline götür- & 23 & otomobil & 3 & böc & & 1 & şoför \\
\hline birbiri & 22 & ova & 3 & bölr & me & 1 & şüphesiz \\
\hline hayal & 22 & ödül & 3 & buç & & 1 & ta \\
\hline ilk & 22 & paltolu & 3 & buh & & 1 & taban \\
\hline sabah & 22 & parti & 3 & bult & utlu & 1 & tabip \\
\hline doldur- & 22 & perili & 3 & bun & ralım & 1 & tablo \\
\hline kaç- & 22 & piknik & 3 & bun & & 1 & tahmin \\
\hline koy- & 22 & piyango & 3 & bun & nunla beraber & 1 & takı \\
\hline ağız & 21 & postacı & 3 & bur & un deliğgi & 1 & takıntısız \\
\hline belki & 21 & sabahleyin & 3 & bük & zlüm & 1 & takip \\
\hline çiğdem & 21 & sabır & 3 & büy & rücü & 1 & takke \\
\hline hemşire & 21 & samimi & 3 & büy & rükanne & 1 & takkeli \\
\hline kardeş & 21 & saniye & 3 & büy & rüklük & 1 & taksi \\
\hline & $\begin{array}{r}R u \\
\text { Osma }\end{array}$ & $\begin{array}{l}\text { E Dil ve Edebiyat Arc } \\
\text { Mahallesi, Mürver Çiç } \\
\text { Kadkköy - İSTANBUL } \\
\text { e-posta: edi } \\
\text { el: +90 } 5057958124 \text {, }\end{array}$ & $\begin{array}{l}\text { i Sol } \\
\text { TÜR } \\
\text { r@ru } \\
902\end{array}$ & & $\begin{array}{l}\text { Address } \\
\text { RumeliDE Journc } \\
\text { Osmanağa Mahal } \\
\text { Kadlköy - ISTANI } \\
\text { e-mail: editor@r } \\
\text { phone: +90 505 }\end{array}$ & $\begin{array}{l}\text { lesi, } \\
\text { uUL } \\
\text { ume }\end{array}$ & $\begin{array}{l}\text { and Literature Studies } \\
\text { eği Sokak, No:14/8 } \\
34714 \\
16773 \text { o } 616\end{array}$ \\
\hline
\end{tabular}


Türkçenin yabancı dil olarak öğretiminde kullanılan okuma kitaplarındaki söz varlığı ögelerinin incelenmesi / M. Göker; G.

\begin{tabular}{|c|c|c|c|c|c|c|c|}
\hline kenar & 21 & sarsintı & 3 & \multirow{2}{*}{\multicolumn{2}{|c|}{$\begin{array}{l}\text { büyülü } \\
\text { camekan }\end{array}$}} & 1 & tam tamına \\
\hline kız kardeş & 21 & sefa & 3 & & & 1 & tamirat \\
\hline kuruş & 21 & selam & 3 & \multicolumn{2}{|c|}{ camgöbeği } & 1 & tandır ekmeği \\
\hline uzun & 21 & senet & 3 & \multicolumn{2}{|c|}{ cami } & 1 & tanrının günü \\
\hline yok & 21 & sessizlik & 3 & \multicolumn{2}{|c|}{ camii } & 1 & tapu \\
\hline açıkla- & 21 & soğan & 3 & \multicolumn{2}{|c|}{ camlı } & 1 & tarihi \\
\hline kaybet- & 21 & sohbet & 3 & \multicolumn{2}{|c|}{ cankurtaran } & 1 & tasavvuf \\
\hline beyaz & 20 & süpürge & 3 & \multicolumn{2}{|c|}{ cansiz } & 1 & tavir \\
\hline edebiyat & 20 & sürekli & 3 & \multicolumn{2}{|c|}{ cefa } & 1 & tavırlı \\
\hline isim & 20 & şakacı & 3 & \multicolumn{2}{|c|}{ cenaze } & 1 & tavuk suyu \\
\hline neden & 20 & şapka & 3 & \multicolumn{2}{|c|}{ cennet } & 1 & taze \\
\hline önce & 20 & şarap & 3 & \multicolumn{2}{|c|}{ cephe } & 1 & tebessüm \\
\hline önemli & 20 & şeytan & 3 & \multicolumn{2}{|c|}{ cerrah } & 1 & tebrik \\
\hline bekle- & 20 & şık & 3 & \multicolumn{2}{|c|}{ ceset } & 1 & tecrübe \\
\hline cevapla- & 20 & tabi & 3 & \multicolumn{2}{|c|}{ cetvel } & 1 & tedavi \\
\hline hepsi & 19 & tabiat & 3 & \multicolumn{2}{|c|}{ cevval } & 1 & tedirgin \\
\hline sev- & 19 & tanıdık & 3 & \multicolumn{2}{|c|}{ ceylan } & 1 & teğmen \\
\hline araba & 18 & tekerlek & 3 & \multicolumn{2}{|c|}{ civiltı } & 1 & tek başına \\
\hline biri & 18 & teklif & 3 & \multicolumn{2}{|c|}{ cizırtı } & 1 & tekerlekli \\
\hline çünkü & 18 & telaş & 3 & \multicolumn{2}{|c|}{ ciğerci } & 1 & tekir \\
\hline hep & 18 & telkin & 3 & \multicolumn{2}{|c|}{ cihan } & 1 & tel \\
\hline kahve & 18 & tereddüt & 3 & \multicolumn{2}{|c|}{ cila } & 1 & televizyon \\
\hline kim & 18 & tez & 3 & \multicolumn{2}{|c|}{ cimri } & 1 & telgraf \\
\hline kişi & 18 & torun & 3 & \multicolumn{2}{|c|}{ cisim } & 1 & tellal \\
\hline kurbağa & 18 & tüccar & 3 & \multicolumn{2}{|c|}{ civar } & 1 & tema \\
\hline mahalle & 18 & türkü & 3 & \multicolumn{2}{|c|}{ coğrafya } & 1 & temsilci \\
\hline öykü & 18 & tüy & 3 & cum & ahuriyet & 1 & teneffüs \\
\hline sene & 18 & ufacik & 3 & cüb & & 1 & teorik \\
\hline şu & 18 & utanç & 3 & cüm & abüş & 1 & tepeden tırnağa \\
\hline devam et- & 18 & uzunca & 3 & cüzc & dan & 1 & teras \\
\hline öl- & 18 & üçüncü & 3 & çă̆ & & 1 & ters \\
\hline $\tan 1^{-}$ & 18 & veya & 3 & çağı & rilış & 1 & tersine \\
\hline var- & 18 & virane & 3 & çalg & & 1 & tesadüf \\
\hline ana & 17 & yabancı & 3 & çalı & şkan & 1 & test \\
\hline ayak & 17 & yalnızca & 3 & çam & nur & 1 & teşekkür \\
\hline dağ & 17 & yanak & 3 & çam & nurlu & 1 & teyze \\
\hline fazla & 17 & yapı & 3 & çan & & 1 & tıkanık \\
\hline hanım & 17 & yaprak & 3 & çap & & 1 & tırnak \\
\hline iyi & 17 & yarım & 3 & çar & pintı & 1 & ticarethane \\
\hline nere & 17 & yayla & 3 & çatı & k kaşlı & 1 & tilki \\
\hline & $\begin{array}{r}R u \\
\text { Osma }\end{array}$ & $\begin{array}{r}\text { DE Dil ve Edeb } \\
\text { Mahallesi, Mü } \\
\text { Kadıköy - ÍST } \\
\text { e-po } \\
\text { tel: +90 } 5057\end{array}$ & Tü & & $\begin{array}{l}\text { Address } \\
\text { RumeliDE } \\
\text { Osmanağa } \\
\text { Kadıköy - I } \\
\text { e-mail: ed } \\
\text { phone: }+9\end{array}$ & $\begin{array}{l}\text { llesi, } \\
\text { BUL } \\
\text { rum } \\
795\end{array}$ & $\begin{array}{l}\text { and Literature Studies } \\
\text { ceği Sokak, No:14/8 } \\
34714 \\
216773 \text { 0 } 616\end{array}$ \\
\hline
\end{tabular}


Examination of vocabulary items in reading books used in teaching Turkish as a foreign language / M. Göker; G. Göçen (pp. 407-446)

\begin{tabular}{|c|c|c|c|c|c|c|c|}
\hline yaralı & 17 & yayvan & 3 & \multicolumn{2}{|c|}{ çatlak } & 1 & tipi \\
\hline ağla- & 17 & yaz & 3 & \multicolumn{2}{|c|}{ çavuş } & 1 & titiz \\
\hline kullan- & 17 & yiyecek & 3 & \multicolumn{2}{|c|}{ çay } & 1 & tiyatro \\
\hline an & 16 & yumuşak & 3 & \multicolumn{2}{|c|}{ çay bardağ } & 1 & tohum \\
\hline dört & 16 & yurt & 3 & \multicolumn{2}{|c|}{ çayhane } & 1 & tokalı \\
\hline işte & 16 & yurtdışı & 3 & \multicolumn{2}{|c|}{ çayırlık } & 1 & tokmak \\
\hline kelime & 16 & yuva & 3 & \multicolumn{2}{|c|}{ çekiliş } & 1 & tomar \\
\hline renk & 16 & yük & 3 & \multicolumn{2}{|c|}{ çember } & 1 & tomurcuk \\
\hline taş & 16 & zar & 3 & \multicolumn{2}{|c|}{ çene } & 1 & ton \\
\hline ülke & 16 & zavallı & 3 & \multicolumn{2}{|c|}{ çerçeve } & 1 & topal \\
\hline at- & 16 & zillet & 3 & \multicolumn{2}{|c|}{ çeşit } & 1 & toplu \\
\hline çek- & 16 & acl- & 3 & \multicolumn{2}{|c|}{ çıkış } & 1 & topluluk \\
\hline duy- & 16 & anlaş- & 3 & \multicolumn{2}{|c|}{ çıkış noktası } & 1 & toplumculuk \\
\hline düş- & 16 & bat- & 3 & \multicolumn{2}{|c|}{ çıngırak } & 1 & toplumsal \\
\hline gez- & 16 & benzet- & 3 & \multicolumn{2}{|c|}{ çrak } & 1 & toptancı \\
\hline sür- & 16 & bildir- & 3 & \multicolumn{2}{|c|}{ çiçekçi } & 1 & toz \\
\hline topla- & 16 & boşal- & 3 & \multicolumn{2}{|c|}{ çiçekli } & 1 & trafik kazası \\
\hline ay & 15 & büzül- & 3 & \multicolumn{2}{|c|}{ çiçeklik } & 1 & tuhafiye \\
\hline başhekim & 15 & cevap ver- & 3 & \multicolumn{2}{|c|}{ çĭg } & 1 & turna \\
\hline bazı & 15 & çıkart- & 3 & \multicolumn{2}{|c|}{ çilli } & 1 & turşu \\
\hline birlikte & 15 & çiz- & 3 & \multicolumn{2}{|c|}{ çiriş çanağı } & 1 & tutam \\
\hline cümle & 15 & don- & 3 & \multicolumn{2}{|c|}{ çizili } & 1 & tutku \\
\hline defa & 15 & doy- & 3 & \multicolumn{2}{|c|}{ çocukça } & 1 & tuzak \\
\hline eski & 15 & eğ- & 3 & \multicolumn{2}{|c|}{ çocuksu } & 1 & tuzcu \\
\hline etraf & 15 & eğil- & 3 & \multicolumn{2}{|c|}{ çoğunluk } & 1 & tül \\
\hline halayık & 15 & et- & 3 & çok & & 1 & tülbent \\
\hline 1şık & 15 & etkilen- & 3 & çon & nak & 1 & tünel \\
\hline ihtiyar & 15 & ferahla- & 3 & çor & & 1 & tür \\
\hline roman & 15 & geliştir- & 3 & çorl & & 1 & $\begin{array}{l}\text { türk dili edebiyatı } \\
\text { bölümü }\end{array}$ \\
\hline tek & 15 & gerçekleş- & 3 & çök & ük & 1 & türkçülük \\
\hline yalnız & 15 & gizlen- & 3 & çöl & & 1 & türkiyeli \\
\hline dinle- & 15 & göç et- & 3 & çöp & teneke & 1 & tütünsüz \\
\hline göster- & 15 & gözük- & 3 & çör & & 1 & tüylü \\
\hline iç- & 15 & güçlük çek- & 3 & çub & uk & 1 & ucuz \\
\hline in- & 15 & hayret et- & 3 & dad & & 1 & uçurtma \\
\hline akşam & 14 & inle- & 3 & dağ & başı & 1 & uğurlu \\
\hline aşk & 14 & isabet et- & 3 & dağ & flnıklık & 1 & uğursuzluk \\
\hline bey & 14 & işle- & 3 & dağ & sitım yeri & 1 & umman \\
\hline birkaç & 14 & karar ver- & 3 & dah & & 1 & umutsuz \\
\hline & $\begin{array}{r}R 2 \\
\text { Osme } \\
\end{array}$ & $\begin{array}{r}\text { E Dil ve Edebiyat } \\
\text { Mahallesi, Mürver } \\
\text { Kadıöy - ÍSTANE } \\
\text { e-posta: } \\
\text { el: +90 } 50579581\end{array}$ & 1 & 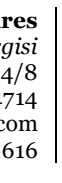 & $\begin{array}{l}\text { Address } \\
\text { RumeliDE J } \\
\text { Osmanağa N } \\
\text { Kadıöy - IS } \\
\text { e-mail: edit } \\
\text { phone: }+90\end{array}$ & 795 & $\begin{array}{l}\text { and Literature Studies } \\
\text { eği Sokak, No:14/8 } \\
34714 \\
16773 \text { o } 616\end{array}$ \\
\hline
\end{tabular}


Türkçenin yabancı dil olarak öğretiminde kullanılan okuma kitaplarındaki söz varlığı ögelerinin incelenmesi / M. Göker; G.

\begin{tabular}{|c|c|c|c|c|c|c|}
\hline derviş & 14 & kat- & 3 & daimi & 1 & un çorbası \\
\hline diğer & 14 & katıl- & 3 & dalavere & 1 & unutkan \\
\hline dikkat & 14 & kay- & 3 & dalya & 1 & uskumru \\
\hline dil & 14 & kaz- & 3 & dantela & 1 & usta \\
\hline duvar & 14 & kırıl- & 3 & dar & 1 & ustaca \\
\hline efendi & 14 & kızar- & 3 & daracık & 1 & usul \\
\hline fare & 14 & kurtar- & 3 & davar & 1 & uşak \\
\hline genç & 14 & mat et- & 3 & davullu & 1 & uydum akıllı \\
\hline herkes & 14 & meşgul ol- & 3 & dayak & 1 & uygun \\
\hline komşu & 14 & mutlu ol- & 3 & dayalı & 1 & uysal \\
\hline nihayet & 14 & mümkün ol- & 3 & dayanılmaz & 1 & uzakça \\
\hline oyun & 14 & nefes al- & 3 & dedikodu & 1 & uzunluk \\
\hline pencere & 14 & okut- & 3 & dedikoducu & 1 & ücra \\
\hline peri & 14 & öfkelen- & 3 & deli & 1 & üç yüz bin \\
\hline resim & 14 & öğret- & 3 & delikanlılık & 1 & üç yüz otuz \\
\hline satıcı & 14 & önemse- & 3 & delil & 1 & üçer \\
\hline $\operatorname{tane}$ & 14 & paylaş- & 3 & demek ki & 1 & $\begin{array}{l}\text { üfürsen uçacak } \\
\text { gibi }\end{array}$ \\
\hline ya & 14 & sahura kalk- & 3 & deminden beri & 1 & ümitsiz \\
\hline bulun- & 14 & saklan- & 3 & demir kapı & 1 & ümmet \\
\hline çağır- & 14 & sallan- & 3 & denge & 1 & $\begin{array}{l}\text { ümmet i } \\
\text { muhammed }\end{array}$ \\
\hline kaldır- & 14 & say- & 3 & dergah & 1 & ün \\
\hline öğren- & 14 & sığın- & 3 & deste & 1 & ürpertici \\
\hline sus- & 14 & sil- & 3 & detaylı & 1 & üst kat \\
\hline aynı & 13 & süpür- & 3 & devetüyü & 1 & üstat \\
\hline $\mathrm{az}$ & 13 & süz- & 3 & devre & 1 & üstün \\
\hline çanta & 13 & tak- & 3 & dış görünüş & 1 & üstüne \\
\hline çekirdek & 13 & takıl- & 3 & diken & 1 & üzerine \\
\hline deyim & 13 & tanış- & 3 & dilci & 1 & vakuf \\
\hline gönül & 13 & tarif et- & 3 & dimağ & 1 & $\begin{array}{l}\text { vakit } \\
\text { kaybetmeden }\end{array}$ \\
\hline hiçbir & 13 & taş- & 3 & diplomat & 1 & vakitsiz \\
\hline ip & 13 & ter dök- & 3 & direkler arası & 1 & vakti \\
\hline kitap & 13 & toplan- & 3 & dirsek & 1 & valiz \\
\hline padişah & 13 & tüken- & 3 & dişsizlik & 1 & vardiye \\
\hline sadece & 13 & uzan- & 3 & divan edebiyatı & 1 & vasita \\
\hline saksı & 13 & ürk- & 3 & divane & 1 & vatan \\
\hline sizce & 13 & vefat et- & 3 & diyalog & 1 & vay anasına \\
\hline yaş & 13 & vurul- & 3 & diyar & 1 & vaziyet \\
\hline yer ver- & 13 & vuruş- & 3 & dizi & 1 & vezne \\
\hline
\end{tabular}

RumeliDE Dil ve Edebiyat Araştırmalar Dergisi Osmanağa Mahallesi, Mürver Çiçeği Sokak, No:14/8 Kadıköy - İSTANBUL / TÜRKIYE 34714 e-posta: editor@rumelide.com tel: +90 $5057958124,+902167730616$
Address

RumeliDE Journal of Language and Literature Studies Osmanağa Mahallesi, Mürver Çiçeği Sokak, No:14/8 Kadıköy - ISTANBUL / TURKEY 34714

e-mail: editor@rumelide.com,

phone: +90 505 7958124, +90 2167730616 
Examination of vocabulary items in reading books used in teaching Turkish as a foreign language / M. Göker; G. Göçen (pp. 407-446)

\begin{tabular}{|c|c|c|c|c|c|c|c|}
\hline benze- & 13 & yasakla- & 3 & \multicolumn{2}{|c|}{ doğa } & 1 & vicık \\
\hline bit- & 13 & yayıl- & 3 & \multicolumn{2}{|c|}{ doğaüstü } & 1 & video \\
\hline görün- & 13 & yeşer- & 3 & \multicolumn{2}{|c|}{ doğrultu } & 1 & vilayet \\
\hline işit- & 13 & yıka- & 3 & \multicolumn{2}{|c|}{ doğruluk } & 1 & vinç \\
\hline kalk- & 13 & yitir- & 3 & \multicolumn{2}{|c|}{$\operatorname{dog} u$} & 1 & viranelik \\
\hline altın & 12 & yola koyul- & 3 & \multicolumn{2}{|c|}{ doğum } & 1 & virgülsüz \\
\hline ancak & 12 & yorul- & 3 & \multicolumn{2}{|c|}{ doğum tarihi } & 1 & vitrinli \\
\hline dış & 12 & zorlan- & 3 & \multicolumn{2}{|c|}{ doğumlu } & 1 & ya ya \\
\hline hava & 12 & mart & 2 & \multicolumn{2}{|c|}{ doktora } & 1 & yabani \\
\hline hem & 12 & adamcağız & 2 & \multicolumn{2}{|c|}{ dolayı } & 1 & yabani ot \\
\hline ikramiye & 12 & adlı & 2 & \multicolumn{2}{|c|}{ dolayısıyla } & 1 & yağlı \\
\hline kağıt & 12 & ağa & 2 & \multicolumn{2}{|c|}{ dolma } & 1 & yağmurlu \\
\hline kalabalık & 12 & ak sakallı & 2 & \multicolumn{2}{|c|}{ dolunay } & 1 & yahu \\
\hline kulak & 12 & akıcı & 2 & \multicolumn{2}{|c|}{ don } & 1 & yakında \\
\hline kutucuk & 12 & alan & 2 & \multicolumn{2}{|c|}{ dondurma } & 1 & yakışıklı \\
\hline niçin & 12 & alçak & 2 & \multicolumn{2}{|c|}{ donuk } & 1 & yalçın \\
\hline olay & 12 & alçakgönüllü & 2 & \multicolumn{2}{|c|}{ donukluk } & 1 & yaldızlı \\
\hline ortanca & 12 & alışkanlık & 2 & \multicolumn{2}{|c|}{ dönüş } & 1 & yalnızlık \\
\hline türlü & 12 & anında & 2 & \multicolumn{2}{|c|}{ dört bir yan } & 1 & yamaç \\
\hline ara- & 12 & anmalık & 2 & \multicolumn{2}{|c|}{ dört yol ağzı } & 1 & yamalı \\
\hline bağır- & 12 & ansiklopedi & 2 & \multicolumn{2}{|c|}{ durak } & 1 & yangin \\
\hline bitir- & 12 & arada & 2 & \multicolumn{2}{|c|}{ durgunluk } & 1 & yanı başı \\
\hline çevir- & 12 & arzu & 2 & \multicolumn{2}{|c|}{ duvarlı } & 1 & yanı başında \\
\hline dayan- & 12 & askerlik & 2 & \multicolumn{2}{|c|}{ düğme } & 1 & yanık ses \\
\hline uyu- & 12 & aşçı & 2 & \multicolumn{2}{|c|}{ dükkan } & 1 & yanlışlıkla \\
\hline yak- & 12 & aşırı & 2 & dür & tyaca & 1 & yansıma \\
\hline art & 11 & aşk hikayesi & 2 & $\begin{array}{l}\text { dün } \\
\text { ucu }\end{array}$ & hyanın öbür & 1 & yapayalnız \\
\hline beyin & 11 & at arabası & 2 & düş & ünceli & 1 & yaptırım \\
\hline çarşı & 11 & atlı & 2 & düz & & 1 & yaramazlık \\
\hline deniz & 11 & ayaz & 2 & düz & en & 1 & yarık \\
\hline deri & 11 & ayıp & 2 & düz & enbaz & 1 & yarışma \\
\hline dolu & 11 & aynı zamanda & 2 & düz & enbazlık & 1 & yas \\
\hline durum & 11 & ayrı & 2 & düz & enli & 1 & yaslı \\
\hline et & 11 & azıcık & 2 & düz & lük & 1 & yastık \\
\hline göğüs & 11 & bağlı & 2 & $\mathrm{e}$ & & 1 & yaşayış \\
\hline karanlık & 11 & bahçeli & 2 & ebr & ulu & 1 & yaşlı gözyaşı \\
\hline kimse & 11 & balık & 2 & ede & & 1 & yatılı \\
\hline koca & 11 & banka & 2 & edit & törlük & 1 & yavaş \\
\hline lira & 11 & başlangiç & 2 & ee & & 1 & yaya \\
\hline & $\begin{array}{r}R l \\
\text { Osm } \\
\end{array}$ & $\begin{array}{l}\text { E Dil ve Edebiyat Arc } \\
\text { Mahallesi, Mürver CCiç } \\
\text { Kadıköy - İSTANBUL } \\
\text { e-posta: edi } \\
\text { el: +90 } 5057958124,\end{array}$ & $\begin{array}{l}\text { trrm } \\
\text { î Sol } \\
\text { Tü } \\
\text { r@r } \\
902\end{array}$ & & $\begin{array}{l}\text { Address } \\
\text { RumeliDE Jour } \\
\text { Osmanağa Mah } \\
\text { Kadıköy - ISTA } \\
\text { e-mail: editor } \\
\text { phone: +90 5c }\end{array}$ & 795 & $\begin{array}{l}\text { and Literature Studies } \\
\text { ắ Sokak, No:14/8 } \\
34714 \\
216773 \text { o } 616\end{array}$ \\
\hline
\end{tabular}


Türkçenin yabancı dil olarak öğretiminde kullanılan okuma kitaplarındaki söz varlığı ögelerinin incelenmesi / M. Göker; G.

\begin{tabular}{|c|c|c|c|c|c|c|c|}
\hline okul & 11 & başucu & 2 & \multicolumn{2}{|c|}{ eflatun } & 1 & yayan \\
\hline orta & 11 & bebek & 2 & \multicolumn{2}{|c|}{ eflatuni } & 1 & уауın \\
\hline öğretmenlik & 11 & beklenti & 2 & \multicolumn{2}{|c|}{ eğitimli } & 1 & yayınevi \\
\hline sarı & 11 & belediye & 2 & \multicolumn{2}{|c|}{ eğri } & 1 & yazı tahtası \\
\hline sihirbaz & 11 & benekli & 2 & \multicolumn{2}{|c|}{ ehemmiyet } & 1 & yazılı \\
\hline sol & 11 & beraberce & 2 & \multicolumn{2}{|c|}{ ekonomi } & 1 & yazışma \\
\hline şekil & 11 & bereketli & 2 & \multicolumn{2}{|c|}{ ekşi } & 1 & yazma \\
\hline yazı & 11 & bereli & 2 & \multicolumn{2}{|c|}{ el ayası } & 1 & yazmacı \\
\hline yemek & 11 & beş bin & 2 & \multicolumn{2}{|c|}{ elalem } & 1 & yekpare \\
\hline zaten & 11 & beş yüz & 2 & \multicolumn{2}{|c|}{ elçilik } & 1 & yelek \\
\hline geçir- & 11 & beş yüz kırk & 2 & \multicolumn{2}{|c|}{ eleştirmen } & 1 & yelekli \\
\hline kork- & 11 & beş yüz otuz & 2 & \multicolumn{2}{|c|}{ elli beşinci } & 1 & yemek odası \\
\hline oyna- & 11 & beybaba & 2 & \multicolumn{2}{|c|}{ elmacık kemiği } & 1 & yemeni \\
\hline san- & 11 & bıyık & 2 & \multicolumn{2}{|c|}{ emanet } & 1 & yemiş \\
\hline vur- & 11 & bıyıklı & 2 & \multicolumn{2}{|c|}{ emin } & 1 & yemyeşil \\
\hline abi & 10 & bilgin & 2 & \multicolumn{2}{|c|}{ enayi } & 1 & yenge \\
\hline aile & 10 & $\begin{array}{l}\text { bin altı yüz } \\
\text { seksen iki }\end{array}$ & 2 & \multicolumn{2}{|c|}{ enerji kaynağı } & 1 & yeni yetme \\
\hline anahtar & 10 & $\begin{array}{l}\text { bin dokuz yüz } \\
\text { otuz iki }\end{array}$ & 2 & \multicolumn{2}{|c|}{ enişte } & 1 & yenilik \\
\hline anlam & 10 & $\begin{array}{l}\text { bin dokuz yüz } \\
\text { otuz yedi }\end{array}$ & 2 & \multicolumn{2}{|c|}{ enlemesine } & 1 & yer altı \\
\hline bekçi & 10 & $\begin{array}{l}\text { bin dokuz yüz } \\
\text { yetmiş dört }\end{array}$ & 2 & \multicolumn{2}{|c|}{ entelektüel } & 1 & yer sofrası \\
\hline birdenbire & 10 & $\begin{array}{l}\text { bin sekiz yüz } \\
\text { seksen üç }\end{array}$ & 2 & \multicolumn{2}{|c|}{ erkek kardeş } & 1 & yerleşimci \\
\hline cevap & 10 & bina & 2 & \multicolumn{2}{|c|}{ erkekli } & 1 & yerli yerinde \\
\hline dergi & 10 & boru & 2 & \multicolumn{2}{|c|}{ ermeni } & 1 & yetenek \\
\hline düşünce & 10 & bostan & 2 & \multicolumn{2}{|c|}{ esinti } & 1 & yeteri kadar \\
\hline gelin & 10 & boşluk & 2 & \multicolumn{2}{|c|}{ esir } & 1 & yeterli \\
\hline gül & 10 & bozkır & 2 & \multicolumn{2}{|c|}{ eskiden } & 1 & yetim \\
\hline halk & 10 & bu arada & 2 & esn & & 1 & yetmiş beşlik \\
\hline hatta & 10 & bu sırada & 2 & esn & & 1 & yığın \\
\hline kısa & 10 & bulmaca & 2 & esp & rili & 1 & yıkıntı \\
\hline kol & 10 & bulut & 2 & eşe & karısı & 1 & yılan derisi \\
\hline memur & 10 & cadde & 2 & eşil & & 1 & yılbaşı \\
\hline numara & 10 & canım & 2 & eşit & & 1 & yıldırım \\
\hline oğlan & 10 & canlı & 2 & eşli & & 1 & yiğit \\
\hline öte & 10 & cehennem & 2 & evl & halkı & 1 & yirmi beşlik \\
\hline para & 10 & cezaevi & 2 & evla & atlik & 1 & yirminci \\
\hline parça & 10 & cilız & 2 & evli & & 1 & yoğun \\
\hline saat & 10 & cilt & 2 & evli & ilik & 1 & yoğurt \\
\hline & $\begin{array}{r}R 2 \\
\text { Osm }\end{array}$ & $\begin{array}{l}\text { E Dil ve Edebiyat Ar } \\
\text { Mahallesi, Mürver Cic } \\
\text { Kadıöy - ISTANBUI } \\
\text { e-posta: edi } \\
\text { el: +90 } 5057958124\end{array}$ & 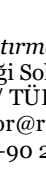 & & $\begin{array}{l}\text { Address } \\
\text { RumeliDE Jour } \\
\text { Osmanağa Mah } \\
\text { Kadıköy - ISTA } \\
\text { e-mail: editor } \\
\text { phone: +90 } 50\end{array}$ & $\begin{array}{l}\text { lesi, } \\
\text { BUL } \\
\text { cume } \\
795\end{array}$ & $\begin{array}{l}\text { and Literature Studies } \\
\text { ắ Sokak, No:14/8 } \\
34714 \\
216773 \text { o } 616\end{array}$ \\
\hline
\end{tabular}


Examination of vocabulary items in reading books used in teaching Turkish as a foreign language / M. Göker; G. Göçen (pp. 407-446)

\begin{tabular}{|c|c|c|c|c|c|c|c|}
\hline sira & 10 & $\operatorname{cin}$ & 2 & \multicolumn{2}{|c|}{ evliya } & 1 & yokluk \\
\hline uzak & 10 & çaba & 2 & \multicolumn{2}{|c|}{ eylem } & 1 & yoksul \\
\hline üniversite & 10 & çabucak & 2 & \multicolumn{2}{|c|}{ ezici } & 1 & yolak \\
\hline vakit & 10 & çabuk & 2 & \multicolumn{2}{|c|}{ fakülte } & 1 & yoldaş \\
\hline vapur & 10 & çekicilik & 2 & \multicolumn{2}{|c|}{ falanca } & 1 & yönetici \\
\hline yani & 10 & çevre & 2 & \multicolumn{2}{|c|}{ falcılık } & 1 & yuvarlak \\
\hline yeni & 10 & çeyiz & 2 & \multicolumn{2}{|c|}{ fanus } & 1 & yüce \\
\hline doğ- & 10 & çılak & 2 & \multicolumn{2}{|c|}{ fasil } & 1 & yüksek lisans \\
\hline kavuş- & 10 & çilingir & 2 & \multicolumn{2}{|c|}{ fayda } & 1 & yükseköğrenim \\
\hline kaybol- & 10 & çim & 2 & \multicolumn{2}{|c|}{ fazlaca } & 1 & yüz elli \\
\hline tut- & 10 & $\begin{array}{l}\text { çocuk hakları } \\
\text { sözleşmesi }\end{array}$ & 2 & \multicolumn{2}{|c|}{ fazlalık } & 1 & yüz seksen \\
\hline acl & 9 & çok geçmeden & 2 & \multicolumn{2}{|c|}{ felaket } & 1 & yüz yumuşaklığ \\
\hline ahlat & 9 & dağıtım & 2 & \multicolumn{2}{|c|}{$\begin{array}{l}\text { fen edebiyat } \\
\text { fakültesi }\end{array}$} & 1 & yüzbaşı \\
\hline ait & 9 & dahi & 2 & \multicolumn{2}{|c|}{ fena halde } & 1 & yüzbinlerce \\
\hline altı & 9 & dair & 2 & \multicolumn{2}{|c|}{ feryat } & 1 & yüzlerce \\
\hline ateş & 9 & dakikalık & 2 & \multicolumn{2}{|c|}{ fetih } & 1 & yüzlü \\
\hline beri & 9 & dalgin & 2 & \multicolumn{2}{|c|}{ fikra } & 1 & yüzükoyun \\
\hline birden & 9 & darp & 2 & \multicolumn{2}{|c|}{ firça } & 1 & zaaf \\
\hline çeşme & 9 & dede & 2 & \multicolumn{2}{|c|}{ firlak } & 1 & zam \\
\hline çocukluk & 9 & değerli & 2 & \multicolumn{2}{|c|}{ fiskiye } & 1 & zelzele \\
\hline daima & 9 & değişik & 2 & \multicolumn{2}{|c|}{ fistık } & 1 & zenginlik \\
\hline dal & 9 & delikanlı & 2 & \multicolumn{2}{|c|}{ filanca } & 1 & zevk \\
\hline eğitim & 9 & demin & 2 & \multicolumn{2}{|l|}{ file } & 1 & zevk düşkünü \\
\hline geri & 9 & demir yolu & 2 & \multicolumn{2}{|c|}{ filiz } & 1 & zevk ehli \\
\hline güllaç & 9 & depo & 2 & \multicolumn{2}{|c|}{ fiziksel özellik } & 1 & zevkli \\
\hline haber & 9 & derin & 2 & \multicolumn{2}{|c|}{ florya } & 1 & zeytinlik \\
\hline hoca & 9 & devir & 2 & futb & & 1 & zifos \\
\hline kaç & 9 & devlet & 2 & gali & barda & 1 & ziyafet \\
\hline kalp & 9 & dikkatli & 2 & gay & & 1 & ziyan \\
\hline kırk & 9 & din & 2 & gay & retli & 1 & zurnalı \\
\hline konu & 9 & divan & 2 & gaz & lambası & 1 & adımla- \\
\hline omuz & 9 & dokuz & 2 & gazt & ete kağıdı & 1 & adlandır- \\
\hline sağ & 9 & doruk & 2 & gaze & eteci & 1 & affet- \\
\hline sandık & 9 & dostluk & 2 & gece & elerce & 1 & aksat- \\
\hline sevinç & 9 & dua & 2 & gece & elik & 1 & akset- \\
\hline şöyle & 9 & duru & 2 & gece & elik elbise & 1 & alay et- \\
\hline uç & 9 & düğüm & 2 & geçi & & 1 & aldat- \\
\hline ya da & 9 & düm tek & 2 & ged & ikli & 1 & alıklaş- \\
\hline & $\begin{array}{r}R u \\
\text { Osma }\end{array}$ & $\begin{array}{l}\text { E Dil ve Edebiyat Ar } \\
\text { Mahallëi, Mürver Cic } \\
\text { Kadıöy - ISTANBUI } \\
\text { e-posta: edi } \\
\text { el: +90 } 5057958124\end{array}$ & Si To & 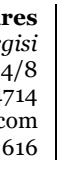 & $\begin{array}{l}\text { Address } \\
\text { RumeliDE Jou } \\
\text { Osmanağa Ma } \\
\text { Kadıöy - ISTA } \\
\text { e-mail: editor } \\
\text { phone: +90 } 5\end{array}$ & $\begin{array}{l}\text { al of } \\
\text { lesi, } \\
\text { BUL } \\
\text { rume } \\
795\end{array}$ & $\begin{array}{l}\text { and Literature Studies } \\
\text { eği Sokak, No:14/8 } \\
34714 \\
16773 \text { o } 616\end{array}$ \\
\hline
\end{tabular}


Türkçenin yabancı dil olarak öğretiminde kullanılan okuma kitaplarındaki söz varlığı ögelerinin incelenmesi / M. Göker; G.

\begin{tabular}{|c|c|c|c|c|c|c|}
\hline yaban & 9 & düş & 2 & gelecek & 1 & alıkoy- \\
\hline yara & 9 & düşman & 2 & gelincik & 1 & aran- \\
\hline yavru & 9 & düşünce yazısı & 2 & gelinlik & 1 & arat- \\
\hline bağla- & 9 & eczane & 2 & gencecik & 1 & atan- \\
\hline bin- & 9 & eğlence & 2 & genel & 1 & ateşlen- \\
\hline gönder- & 9 & eh & 2 & gerçekçi & 1 & avla- \\
\hline karşılaş- & 9 & el yazısı & 2 & gerdan & 1 & ayakta dur- \\
\hline kır- & 9 & elbette & 2 & gevrek & 1 & azal- \\
\hline salla- & 9 & eldiven & 2 & gezi yazısı & 1 & bağlan- \\
\hline belli & 8 & eldivenli & 2 & girtlak & 1 & bahşiş topla- \\
\hline beraber & 8 & erkeksiz & 2 & gider harcama & 1 & barın- \\
\hline bölüm & 8 & etken & 2 & gidiş & 1 & batır- \\
\hline bugün & 8 & ev sahibi & 2 & gidişat & 1 & bayl- \\
\hline burun & 8 & evvel & 2 & giriş bölümü & 1 & bekleme- \\
\hline cep & 8 & fes & 2 & girişimci & 1 & bekleş- \\
\hline dere & 8 & firtına & 2 & giysi & 1 & beklet- \\
\hline elli & 8 & fukara & 2 & gizlice & 1 & belli et- \\
\hline fakir & 8 & gaga & 2 & gonca & 1 & besle- \\
\hline filan & 8 & garip & 2 & göl & 1 & biç- \\
\hline gökyüzü & 8 & gaz & 2 & gönderici & 1 & bina et- \\
\hline hala & 8 & geçit & 2 & gönül borcu & 1 & bit-(yeşermek) \\
\hline haminne & 8 & geçmiş & 2 & gönül darlığg & 1 & boğazla- \\
\hline hareket & 8 & gedik & 2 & gönül rahatlığı & 1 & boşalt- \\
\hline hele & 8 & gelenek & 2 & gönülsüzce & 1 & boşan- \\
\hline imam & 8 & gelişme bölümü & 2 & görevli & 1 & boy ver- \\
\hline kafes & 8 & gezgin & 2 & görgülü & 1 & boynuna sarıl- \\
\hline kalem & 8 & gida & 2 & görüntü & 1 & buda- \\
\hline kara & 8 & gizli & 2 & görünür & 1 & buruş- \\
\hline karı & 8 & gömlek & 2 & görünüş & 1 & bükül- \\
\hline karşılık & 8 & görenek & 2 & gövde & 1 & büyütül- \\
\hline kötü & 8 & görümce & 2 & göz alıcı & 1 & cesaret et- \\
\hline lise & 8 & görüş & 2 & gözlemci & 1 & civilda- \\
\hline mahcup & 8 & gözlem & 2 & gözlük & 1 & çarpıl- \\
\hline pek & 8 & gurbet & 2 & gram & 1 & çarpış- \\
\hline rağmen & 8 & gurur & 2 & gri & 1 & çekin- \\
\hline sebep & 8 & güfte & 2 & gurbetçi & 1 & çı̆̆ırt- \\
\hline senelik & 8 & güneş 1şı̆̆ı & 2 & güç zor & 1 & çı̆̆lık at- \\
\hline Sinav & 8 & gür & 2 & güçlü & 1 & çığlık kop- \\
\hline sigara & 8 & güzellik & 2 & güçlük & 1 & çıldır- \\
\hline sonunda & 8 & habersiz & 2 & güle & 1 & çınlat- \\
\hline & & $\begin{array}{l}\text { E Dil ve Edebiyat Araş, } \\
\text { Mahallesi, Mürver Çiçeğ } \\
\text { Kadıköy - İSTANBUL / } \\
\text { e-posta: edito } \\
\text { el: +90 } 5057958124,+\end{array}$ & $\begin{array}{r}\text { Adre } \\
\text { trrmaları Dergi } \\
\text { í Sokak, No:14/ } \\
\text { TÜRKIYE } 3471 \\
\text { r@rumelide.col } \\
-90216773 \text { o } 61\end{array}$ & \begin{tabular}{l|l} 
es & Address \\
isi & RumeliDE Jou \\
/8 & Osmanağa Ma \\
14 & Kadkköy - ISTA \\
om & e-mail: editor \\
16 & phone: +90 5
\end{tabular} & rum & $\begin{array}{l}\text { and Literature Studies } \\
\text { ắ Sokak, No:14/8 } \\
34714 \\
216773 \text { o } 616\end{array}$ \\
\hline
\end{tabular}


Examination of vocabulary items in reading books used in teaching Turkish as a foreign language / M. Göker; G. Göçen (pp. 407-446)

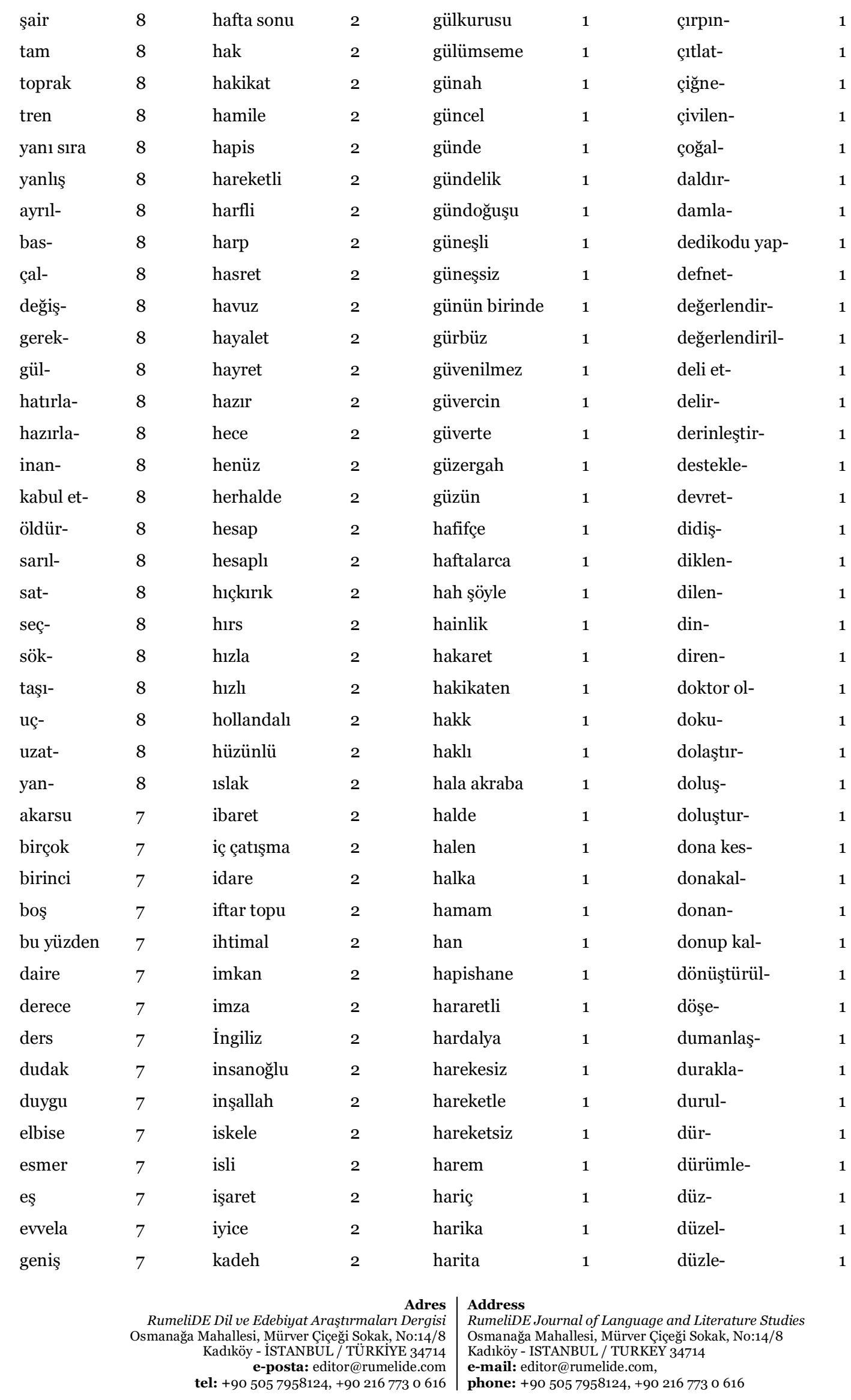


Türkçenin yabancı dil olarak öğretiminde kullanılan okuma kitaplarındaki söz varlığı ögelerinin incelenmesi / M. Göker; G.

\begin{tabular}{|c|c|c|c|c|c|c|c|}
\hline hafta & 7 & kader & 2 & \multicolumn{2}{|l|}{ has } & 1 & efsaneleş- \\
\hline hala zaman & 7 & kahkaha & 2 & \multicolumn{2}{|c|}{ hastalıklı } & 1 & eğitim ver- \\
\hline harf & 7 & kalınlık & 2 & \multicolumn{2}{|c|}{ hat } & 1 & eğlendir- \\
\hline hatira & 7 & kambur & 2 & \multicolumn{2}{|c|}{ hatır } & 1 & eklen- \\
\hline hayır & 7 & kan & 2 & \multicolumn{2}{|c|}{ havale } & 1 & eksik etme- \\
\hline ikinci & 7 & kanepe & 2 & \multicolumn{2}{|c|}{ hayat tecrübesi } & 1 & ekşit- \\
\hline ince & 7 & kapak & 2 & \multicolumn{2}{|c|}{ hayati } & 1 & el çırp- \\
\hline kedi & 7 & kar (yağış) & 2 & \multicolumn{2}{|c|}{ hayır dua } & 1 & el ele tutuş- \\
\hline kır & 7 & karar & 2 & \multicolumn{2}{|c|}{ hayırlı } & 1 & el sıkış- \\
\hline kim bilir & 7 & karış & 2 & \multicolumn{2}{|c|}{ hayırsever } & 1 & emekliye ayrıl- \\
\hline masa & 7 & karne & 2 & \multicolumn{2}{|c|}{ hayli } & 1 & emir ver- \\
\hline mendil & 7 & karşılıklı & 2 & \multicolumn{2}{|c|}{ hayrola } & 1 & endişe et- \\
\hline ne ne & 7 & kavaf & 2 & \multicolumn{2}{|c|}{ hayvansever } & 1 & es- \\
\hline öteki & 7 & kazan & 2 & \multicolumn{2}{|c|}{ hazin } & 1 & eşleştir- \\
\hline özlem & 7 & kendi halinde & 2 & \multicolumn{2}{|l|}{ he } & 1 & evlendir- \\
\hline parmak & 7 & kerata & 2 & \multicolumn{2}{|c|}{ hekim } & 1 & ez- \\
\hline ramazan & 7 & keskin & 2 & \multicolumn{2}{|c|}{ helezonlu } & 1 & ezber et- \\
\hline rüzgar & 7 & kırk birinci & 2 & \multicolumn{2}{|c|}{$\begin{array}{l}\text { hemen hemen } \\
\text { hiç }\end{array}$} & 1 & ezberle- \\
\hline saç & 7 & kırmızı & 2 & \multicolumn{2}{|c|}{ herhangi } & 1 & ezil- \\
\hline sıkıntı & 7 & kısmet & 2 & \multicolumn{2}{|c|}{ heves } & 1 & farkında ol- \\
\hline siyah & 7 & klyafet & 2 & \multicolumn{2}{|c|}{ heybetli } & 1 & faydalan- \\
\hline sonuç & 7 & kızgın & 2 & \multicolumn{2}{|c|}{ hıçkırıklı } & 1 & fethet- \\
\hline süre & 7 & kibrit kutusu & 2 & \multicolumn{2}{|c|}{ hırçın } & 1 & fışkır- \\
\hline tatlı & 7 & kişilik & 2 & \multicolumn{2}{|c|}{ hırka } & 1 & gayret et- \\
\hline tıpkı & 7 & koloni & 2 & \multicolumn{2}{|c|}{ hirsiz } & 1 & geç kal- \\
\hline yağmur & 7 & kök & 2 & hirs & $\mathrm{sSiz}$ & 1 & geçin- \\
\hline yazarlık & 7 & köpek & 2 & hisı & & 1 & geçirt- \\
\hline yedi & 7 & köprü & 2 & hiks & ayecilik & 1 & geliş- \\
\hline yeniden & 7 & kör & 2 & hila & & 1 & genişle- \\
\hline zarf & 7 & kurs & 2 & hily & e i saadet & 1 & gerektir- \\
\hline aydınlık & 7 & kutu & 2 & him & imet & 1 & geri dön- \\
\hline büyü- & 7 & kuvvet & 2 & hipl & hop & 1 & gıdakla- \\
\hline çatla- & 7 & külünk & 2 & his & & 1 & gibi gel- \\
\hline ekle- & 7 & lacivert & 2 & hise & & 1 & gider- \\
\hline evlen- & 7 & lügat & 2 & hiss & siyat & 1 & giriş- \\
\hline giy- & 7 & lütfen & 2 & hişt & & 1 & gizle- \\
\hline karış- & 7 & madde & 2 & hita & & 1 & gol at- \\
\hline kok- & 7 & maddi & 2 & hok & & 1 & göç- \\
\hline seslen- & 7 & maden & 2 & hok & kabaz & 1 & gök gürle- \\
\hline & $\begin{array}{r}R \\
\text { Osm }\end{array}$ & $\begin{array}{l}\text { E Dil ve Edebiyat Ar } \\
\text { Mahallëi, Mürver Cic } \\
\text { Kadıöy - ISTANBUI } \\
\text { e-posta: edi } \\
\text { el: +90 } 5057958124\end{array}$ & Ti TÜ & & $\begin{array}{l}\text { Address } \\
\text { RumeliDE Jour } \\
\text { Osmanağa Mah } \\
\text { Kadıköy - ISTAI } \\
\text { e-mail: editor } \\
\text { phone: }+9050\end{array}$ & $\begin{array}{l}\text { al of } \\
\text { lesi, } \\
\text { BUL } \\
\text { rume } \\
795\end{array}$ & $\begin{array}{l}\text { and Literature Studies } \\
\text { ĕ́i Sokak, No:14/8 } \\
34714 \\
216773 \text { o } 616\end{array}$ \\
\hline
\end{tabular}


Examination of vocabulary items in reading books used in teaching Turkish as a foreign language / M. Göker; G. Göçen (pp. 407-446)

\begin{tabular}{|c|c|c|c|c|c|c|}
\hline vazgeç- & 7 & mahya & 2 & homurtu & 1 & gölgelen- \\
\hline yaklaş- & 7 & mahzen & 2 & horoz & 1 & gönderil- \\
\hline yat- & 7 & mal & 2 & horozibiği & 1 & görmezlikten gel- \\
\hline yerleş- & 7 & marifet & 2 & hortum & 1 & görül- \\
\hline yetiş- & 7 & mavilik & 2 & hoşgörü & 1 & göz kırp- \\
\hline açlk & 6 & medeniyet & 2 & hovarda & 1 & gözlemle- \\
\hline adeta & 6 & memuriyet & 2 & hukuk & 1 & gözlerini kıs- \\
\hline adim & 6 & menekşe & 2 & hurafe & 1 & gözü dol- \\
\hline ah & 6 & mengene & 2 & hususi & 1 & gözü yaşar- \\
\hline aman & 6 & merdiven & 2 & huzur & 1 & gülüş- \\
\hline ayrica & 6 & mermer & 2 & hülya & 1 & gün ağar- \\
\hline bahar & 6 & mesafe & 2 & hülyalı & 1 & güneş aç- \\
\hline bazen & 6 & mesaj & 2 & hür & 1 & gürle- \\
\hline bin & 6 & mezar & 2 & llik & 1 & haber getir- \\
\hline birer & 6 & miktar & 2 & irmak & 1 & haberi ol- \\
\hline boy & 6 & millet & 2 & iftar & 1 & hafifle- \\
\hline böylece & 6 & milletvekillik & 2 & ihanet & 1 & hak et \\
\hline çamaşır & 6 & minnacık & 2 & iki yüz elli & 1 & hakkını helal et- \\
\hline çoğu & 6 & muhabbet & 2 & ikide bir & 1 & halsizleş- \\
\hline dakika & 6 & mukavva & 2 & ikindi vakti & 1 & hapset- \\
\hline değnek & 6 & musiki & 2 & iklim & 1 & hareket et- \\
\hline dilenci & 6 & mutluluk & 2 & iktisat & 1 & harf at- \\
\hline $\operatorname{dip}$ & 6 & müdürlük & 2 & ilahi & 1 & hasta ol- \\
\hline doktor & 6 & mühendis & 2 & ilahi aşk & 1 & hastalan- \\
\hline dost & 6 & müşteri & 2 & ilçe & 1 & hatıra gel- \\
\hline etek & 6 & müthiş & 2 & ileti & 1 & hatim indir- \\
\hline etki & 6 & nargile & 2 & iletişim & 1 & hayır işle- \\
\hline fark & 6 & naylon & 2 & ilgi & 1 & hayran ol- \\
\hline farklı & 6 & nazaran & 2 & ilişkilendir & 1 & hayrette birak- \\
\hline fidan & 6 & nazik & 2 & ilişkili & 1 & hazır et- \\
\hline gerçek & 6 & nazlı & 2 & ilişkin & 1 & hazırlan- \\
\hline gündüz & 6 & ne çare & 2 & ilk bakışta & 1 & hedefine ulaş- \\
\hline hastane & 6 & neşe & 2 & ilk görüşte & 1 & himaye et- \\
\hline havadis & 6 & nevale & 2 & ilkin & 1 & hoşbeş et- \\
\hline hem hem & 6 & nimet & 2 & ilköğrenim & 1 & huzura çık- \\
\hline ileri & 6 & nişanlı & 2 & iltimas & 1 & hücum et- \\
\hline iskemle & 6 & odacı & 2 & iman & 1 & hükmet- \\
\hline karayemiş & 6 & odalı & 2 & imla & 1 & islan- \\
\hline kat & 6 & ok & 2 & imparator & 1 & islat- \\
\hline & & $\begin{array}{r}\text { E Dil ve Edebiyat Ar } \\
\text { Mahallesi, Mürrer Ç } \\
\text { Kadıköy - İSTANBU } \\
\text { e-posta: ec } \\
\text { el: +90 } 505795812\end{array}$ & $\begin{array}{l}\text { si So } \\
\text { Tü } \\
\text { r@r }\end{array}$ & \begin{tabular}{l|l} 
res & Address \\
gisi & RumeliDI \\
$4 / 8$ & Osmanağ \\
714 & Kadıköy - \\
com & e-mail: e \\
616 & phone: +
\end{tabular} & & $\begin{array}{l}\text { and Literature Studies } \\
\text { eği Sokak, No:14/8 } \\
34714 \\
16773 \text { o } 616\end{array}$ \\
\hline
\end{tabular}


Türkçenin yabancı dil olarak öğretiminde kullanılan okuma kitaplarındaki söz varlığı ögelerinin incelenmesi / M. Göker; G.

\begin{tabular}{|c|c|c|c|c|c|c|c|}
\hline kethüda & 6 & okur & 2 & \multicolumn{2}{|c|}{ inanış } & 1 & ismarla- \\
\hline keyif & 6 & olan biten & 2 & \multicolumn{2}{|c|}{ inat } & 1 & israr et- \\
\hline kısaca & 6 & olumsuz & 2 & \multicolumn{2}{|c|}{ inceleme } & 1 & icap et- \\
\hline kış & 6 & $\begin{array}{l}\text { ondan } \\
\text { (busebeple) }\end{array}$ & 2 & \multicolumn{2}{|c|}{ inci } & 1 & içerle- \\
\hline kiracı & 6 & orman & 2 & \multicolumn{2}{|c|}{ ingilizce } & 1 & ihtiyacı ol- \\
\hline masal & 6 & ortalık & 2 & \multicolumn{2}{|c|}{ inmeli } & 1 & ihtiyar ol- \\
\hline mesele & 6 & otuz & 2 & \multicolumn{2}{|c|}{ insaf } & 1 & ihtiyarla- \\
\hline ne var ki & 6 & öğrenci & 2 & \multicolumn{2}{|c|}{ ipince } & 1 & ikram et- \\
\hline nine & 6 & öksürük & 2 & \multicolumn{2}{|c|}{ iplik } & 1 & ikramda bulun- \\
\hline niye & 6 & örtü & 2 & \multicolumn{2}{|c|}{ irade } & 1 & ilaç al- \\
\hline oruç & 6 & pantolon & 2 & \multicolumn{2}{|l|}{ iri } & 1 & ilan et- \\
\hline ot & 6 & paragraf & 2 & \multicolumn{2}{|c|}{ irilik } & 1 & iler- \\
\hline öğretmen & 6 & parasız & 2 & \multicolumn{2}{|c|}{ iskarpinli } & 1 & ilerle- \\
\hline ölüm & 6 & pasaport & 2 & \multicolumn{2}{|c|}{ islam } & 1 & ilikle- \\
\hline ömür & 6 & pastel & 2 & \multicolumn{2}{|c|}{ isteksizlik } & 1 & iliş- \\
\hline özellik & 6 & patlak & 2 & \multicolumn{2}{|c|}{ ister ister } & 1 & imdadına yetiş- \\
\hline post & 6 & peltek & 2 & \multicolumn{2}{|c|}{ istisna } & 1 & imren- \\
\hline rüya & 6 & peş & 2 & \multicolumn{2}{|c|}{ isyan } & 1 & imza at- \\
\hline sahur & 6 & pis & 2 & \multicolumn{2}{|c|}{ işe } & 1 & inandır- \\
\hline sakın & 6 & plastik & 2 & \multicolumn{2}{|c|}{ işporta } & 1 & indir- \\
\hline sanki & 6 & polis & 2 & \multicolumn{2}{|c|}{ işsiz } & 1 & iş yap- \\
\hline satır & 6 & poşet & 2 & \multicolumn{2}{|c|}{ işsizlik } & 1 & işaret et- \\
\hline sevgili & 6 & poyraz & 2 & \multicolumn{2}{|c|}{ itaatkar } & 1 & işe başla- \\
\hline şemsiye & 6 & propaganda & 2 & \multicolumn{2}{|c|}{ itibaren } & 1 & işlet- \\
\hline tahta & 6 & radyo & 2 & \multicolumn{2}{|c|}{ itikat } & 1 & it- \\
\hline talihli & 6 & rahmetli & 2 & itine & & 1 & itina et- \\
\hline tarih & 6 & rakam & 2 & kab & & 1 & iyileştir- \\
\hline tavla & 6 & resmi & 2 & kabs & $\operatorname{arlk}$ & 1 & iz bırak- \\
\hline tekrar & 6 & ressam & 2 & kabi & & 1 & izin ver- \\
\hline tepe & 6 & rol & 2 & kab & ristan & 1 & kabahat işle- \\
\hline testi & 6 & saatlerce & 2 & kaça & & 1 & kabul ol- \\
\hline toplum & 6 & saka & 2 & kaçı & incl & 1 & kahkaha at- \\
\hline torba & 6 & sanat & 2 & kad & lastro & 1 & kalakal- \\
\hline ünlü & 6 & sanatçı & 2 & kadi & & 1 & kalbi sıkış- \\
\hline yaş gözyaşı & 6 & sap & 2 & kah & verengi & 1 & kamil kamil git- \\
\hline yaşam & 6 & saye & 2 & kala & aylı & 1 & kan- \\
\hline yerine & 6 & sayı & 2 & kalb & & 1 & kanitla- \\
\hline yeşil & 6 & sedir & 2 & kald & dırım taşı & 1 & kapan- \\
\hline yeşillik & 6 & sel & 2 & kalı & & 1 & kaparo ver- \\
\hline & $\begin{array}{r}R \\
\text { Osm }\end{array}$ & $\begin{array}{l}\text { E Dil ve Edebiyat } \\
\text { Mahallesi, Mürver } \\
\text { Kadıköy - İSTANB } \\
\text { e-posta: } \\
\text { el: +90 505 79581 }\end{array}$ & 15 & & $\begin{array}{l}\text { Address } \\
\text { RumeliDE J } \\
\text { Osmanağa N } \\
\text { Kadıköy - IS } \\
\text { e-mail: edit } \\
\text { phone: }+9 c\end{array}$ & lesi, & $\begin{array}{l}\text { and Literature Studies } \\
\text { ắi Sokak, No:14/8 } \\
34714 \\
216773 \text { o } 616\end{array}$ \\
\hline
\end{tabular}


Examination of vocabulary items in reading books used in teaching Turkish as a foreign language / M. Göker; G. Göçen (pp. 407-446)

\begin{tabular}{|c|c|c|c|c|c|c|c|}
\hline çarp- & 6 & senelerce & 2 & \multicolumn{2}{|c|}{ kalıntı } & 1 & kapıl- \\
\hline diz- & 6 & sert & 2 & \multicolumn{2}{|c|}{ kalp çarpıntısı } & 1 & kapla- \\
\hline dolaş- & 6 & sessizce & 2 & \multicolumn{2}{|c|}{ kampana } & 1 & kapsa- \\
\hline dök- & 6 & sevda & 2 & \multicolumn{2}{|c|}{ kanal } & 1 & kaptır- \\
\hline gülümse- & 6 & seyahat & 2 & \multicolumn{2}{|c|}{ kanarya } & 1 & karala- \\
\hline hisset- & 6 & seyrek & 2 & \multicolumn{2}{|c|}{ kap } & 1 & kararlı- \\
\hline kur- & 6 & sıçan & 2 & \multicolumn{2}{|c|}{ kapalı } & 1 & karşıllk ver- \\
\hline rastla- & 6 & slkılgan & 2 & \multicolumn{2}{|c|}{ kapan } & 1 & katkıda bulun- \\
\hline tamamla- & 6 & sir & 2 & \multicolumn{2}{|c|}{ kapıcı } & 1 & katla- \\
\hline tokat vur- & 6 & siradan & 2 & \multicolumn{2}{|c|}{ kapılı } & 1 & kavram- \\
\hline uğraş- & 6 & sirt & 2 & \multicolumn{2}{|c|}{ kapkara } & 1 & kavuştur- \\
\hline uzaklaş- & 6 & sihir & 2 & \multicolumn{2}{|c|}{ kaplı } & 1 & kaydet- \\
\hline yakala- & 6 & sinirli & 2 & \multicolumn{2}{|c|}{ kapt } & 1 & kayır- \\
\hline yalvar- & 6 & sonbahar & 2 & \multicolumn{2}{|c|}{ kara tahta } & 1 & kaynak ol- \\
\hline yayınlan- & 6 & stadyum & 2 & \multicolumn{2}{|c|}{ karakalem } & 1 & kaynaklan- \\
\hline yenil- & 6 & surat & 2 & \multicolumn{2}{|c|}{ karakol } & 1 & kazandır- \\
\hline yerleştir- & 6 & susuzluk & 2 & \multicolumn{2}{|c|}{ karakteri } & 1 & kekele- \\
\hline aralık & 5 & sürat & 2 & \multicolumn{2}{|c|}{ karamanlı } & 1 & kesil- \\
\hline ağabey & 5 & sürü & 2 & \multicolumn{2}{|c|}{ karamuk } & 1 & kesiş- \\
\hline akıl & 5 & şairane & 2 & \multicolumn{2}{|c|}{ kararlılık } & 1 & kestir- \\
\hline al & 5 & şarkı & 2 & \multicolumn{2}{|c|}{ karartı } & 1 & kestirebil- \\
\hline asker & 5 & şaşkın & 2 & \multicolumn{2}{|c|}{ karayel } & 1 & keşfet- \\
\hline aşık & 5 & şehit & 2 & \multicolumn{2}{|c|}{ karılı } & 1 & kll- \\
\hline avuç & 5 & şeref & 2 & \multicolumn{2}{|c|}{ karın } & 1 & kımılda- \\
\hline ayakkabı & 5 & şiddet & 2 & \multicolumn{2}{|c|}{$\begin{array}{l}\text { karınca duası } \\
\text { gibi }\end{array}$} & 1 & kıpırdan- \\
\hline ayrıntı & 5 & şimdilik & 2 & kar1 & Işık & 1 & kısal- \\
\hline borç & 5 & şişe & 2 & kari & ikatür & 1 & kisalt- \\
\hline boyunca & 5 & ta kendisi & 2 & karl & & 1 & kivir- \\
\hline cam & 5 & takım & 2 & karl & lı kazançlı & 1 & kıy- \\
\hline can & 5 & takunya & 2 & karr & makarışıklık & 1 & kiralan- \\
\hline çam & 5 & talih & 2 & karş & Şılıksız & 1 & kocaya ver- \\
\hline çare & 5 & talihsiz & 2 & karş & & 1 & kolla- \\
\hline çaresiz & 5 & $\operatorname{tanr} 1$ & 2 & kart & & 1 & kollan- \\
\hline çatı & 5 & tarafindan & 2 & kart & topu & 1 & koluna gir- \\
\hline çatışma & 5 & tarla & 2 & kasa & $\mathrm{aba}$ & 1 & kontrat yap- \\
\hline çeşitli & 5 & tehlike & 2 & kase & & 1 & kopar- \\
\hline dert & 5 & tehlikeli & 2 & kaşı & & 1 & korkut- \\
\hline dişarı & 5 & temel & 2 & kaşl & & 1 & korun- \\
\hline $\operatorname{diz}$ & 5 & temiz & 2 & katı & & 1 & koyul- \\
\hline & $\begin{array}{r}R \\
\text { Osm }\end{array}$ & $\begin{array}{r}\text { E Dil ve Edebiya } \\
\text { Mahallesi, Mürve } \\
\text { Kadıköy - ÍSTAI } \\
\text { e-posta } \\
\text { el: +90 } 505795\end{array}$ & iSo & $\begin{array}{l}\text { res } \\
\text { gisi } \\
4 / 8 \\
1714 \\
\text { com } \\
616\end{array}$ & $\begin{array}{l}\text { Address } \\
\text { RumeliDE Journ } \\
\text { Osmanağa Maha } \\
\text { Kadlköy - ISTAN } \\
\text { e-mail: editor@ } \\
\text { phone: +90 505 }\end{array}$ & $\begin{array}{l}\text { al of } \\
\text { lesi, } \\
\text { BUL } \\
\text { rume } \\
795\end{array}$ & $\begin{array}{l}\text { and Literature Studies } \\
\text { ắi Sokak, No:14/8 } \\
34714 \\
216773 \text { o } 616\end{array}$ \\
\hline
\end{tabular}


Türkçenin yabancı dil olarak öğretiminde kullanılan okuma kitaplarındaki söz varlığı ögelerinin incelenmesi / M. Göker; G.

\begin{tabular}{|c|c|c|c|c|c|c|c|}
\hline dönem & 5 & tenha & 2 & \multicolumn{2}{|c|}{ katılık } & 1 & koyver- \\
\hline düğün & 5 & ter & 2 & \multicolumn{2}{|c|}{ katmerli } & 1 & kötüleş- \\
\hline eğer & 5 & teravih & 2 & \multicolumn{2}{|c|}{ kaya } & 1 & kötüye yor- \\
\hline elma & 5 & terazi & 2 & \multicolumn{2}{|c|}{ kayıр } & 1 & krem sür- \\
\hline ertesi & 5 & terlik & 2 & \multicolumn{2}{|c|}{ kaynana } & 1 & kucakla- \\
\hline fotoğraf & 5 & tesir & 2 & \multicolumn{2}{|c|}{ kaza } & 1 & kul ol- \\
\hline gece yarısı & 5 & usulca & 2 & \multicolumn{2}{|c|}{ kaza ilçe } & 1 & kuluçkaya yat- \\
\hline gençlik & 5 & uyku & 2 & \multicolumn{2}{|c|}{ kazak } & 1 & kurul- \\
\hline gene & 5 & üçgen & 2 & \multicolumn{2}{|c|}{ kazanç } & 1 & kutlu olsun \\
\hline gerek & 5 & ürperti & 2 & \multicolumn{2}{|c|}{ keder } & 1 & kül ol- \\
\hline gölge & 5 & üzgün & 2 & \multicolumn{2}{|l|}{ kel } & 1 & laubali ol- \\
\hline görev & 5 & vagon & 2 & \multicolumn{2}{|c|}{ kemirgen } & 1 & lazım ol- \\
\hline hadi & 5 & vahşi & 2 & \multicolumn{2}{|c|}{ kese } & 1 & lütuf et- \\
\hline heyecan & 5 & vali & 2 & \multicolumn{2}{|c|}{ kese kağıdı } & 1 & meraklan- \\
\hline ifade & 5 & valla & 2 & \multicolumn{2}{|c|}{ kesim } & 1 & mesele aç- \\
\hline ikisi & 5 & vazife & 2 & \multicolumn{2}{|c|}{ kesin } & 1 & meşgul et- \\
\hline ilaç & 5 & vişneçürüğü & 2 & \multicolumn{2}{|c|}{ kesinlikle } & 1 & meydana çlkar- \\
\hline ilgili & 5 & vitrin & 2 & \multicolumn{2}{|c|}{ kestirme yol } & 1 & meydana gel- \\
\hline istek & 5 & viyanalı & 2 & \multicolumn{2}{|c|}{ kıç } & 1 & mezun ol- \\
\hline kafa & 5 & vücut & 2 & \multicolumn{2}{|c|}{ kılıç } & 1 & mihla- \\
\hline kahveci & 5 & yahut & 2 & \multicolumn{2}{|c|}{ kıpkırmızı } & 1 & mirıldan- \\
\hline kaldırım & 5 & yaka & 2 & \multicolumn{2}{|c|}{ kır çiçeği } & 1 & muvaffak ol- \\
\hline kanat & 5 & yalak & 2 & \multicolumn{2}{|c|}{ kırgınlık } & 1 & mücadele et- \\
\hline kar & 5 & yanlışlık & 2 & \multicolumn{2}{|c|}{ kırıntı } & 1 & mücadele ver- \\
\hline karga & 5 & yardımcı & 2 & \multicolumn{2}{|c|}{ kırk bir } & 1 & müjdele- \\
\hline keçi & 5 & yarın & 2 & kırk & dokuz & 1 & müsaade et- \\
\hline kere & 5 & yaşantı & 2 & kırk & zinc1 & 1 & namaz kll- \\
\hline kez & 5 & yatak odası & 2 & kurk & lar & 1 & nasırlan- \\
\hline kırık & 5 & yay & 2 & kırla & angıç & 1 & nesli tüken- \\
\hline kira & 5 & yazıhane & 2 & kırp & & 1 & neşelen- \\
\hline koku & 5 & yazın & 2 & kisa & cası & 1 & neşelendir- \\
\hline koyun & 5 & yıkık & 2 & kıva & & 1 & nişanlı ol- \\
\hline köylü & 5 & yllan & 2 & kıya & afetli & 1 & niyetlen- \\
\hline kral & 5 & yldız & 2 & kıya & & 1 & not et- \\
\hline kural & 5 & yirmi & 2 & kıyı & clk & 1 & oğuştur- \\
\hline külah & 5 & yorgunluk & 2 & kıyn & metli & 1 & okşa- \\
\hline mağaza & 5 & yüksek & 2 & kızı & & 1 & oluştur- \\
\hline mana & 5 & yün & 2 & kızıl & lcık & 1 & onar- \\
\hline mektep & 5 & yüzük & 2 & kızk & kardeş & 1 & oruç tut- \\
\hline mesela & 5 & yüzünden & 2 & kızlı & 1 erkekli & 1 & oruç ye- \\
\hline & $\begin{array}{r}R \\
\text { Osm }\end{array}$ & $\begin{array}{l}\text { E Dil ve Edebiyat } \\
\text { Mahallesi, Mürver } \\
\text { Kadıköy - İSTANB } \\
\text { e-posta: } \\
\text { el: +90 505 } 795812\end{array}$ & 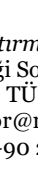 & & $\begin{array}{l}\text { Address } \\
\text { RumeliDE } \\
\text { Osmanağa } \\
\text { Kadıköy - I } \\
\text { e-mail: ed } \\
\text { phone: }+9\end{array}$ & $\begin{array}{l}\text { lesi, } \\
\text { SUL }\end{array}$ & $\begin{array}{l}\text { and Literature Studies } \\
\text { ắi Sokak, No:14/8 } \\
34714 \\
216773 \text { o } 616\end{array}$ \\
\hline
\end{tabular}


Examination of vocabulary items in reading books used in teaching Turkish as a foreign language / M. Göker; G. Göçen (pp. 407-446)

\begin{tabular}{|c|c|c|c|c|c|c|c|}
\hline mevki & 5 & zaylf & 2 & \multicolumn{2}{|c|}{ kibir } & 1 & oruçlu ol- \\
\hline mevsim & 5 & zeka & 2 & \multicolumn{2}{|c|}{ kibirli } & 1 & oynaş- \\
\hline müdür & 5 & zit & 2 & \multicolumn{2}{|c|}{ kibrit } & 1 & oyun oyna- \\
\hline mümkün & 5 & zirve & 2 & \multicolumn{2}{|c|}{ kilit } & 1 & öğretmenlik yap- \\
\hline on & 5 & ziyade & 2 & \multicolumn{2}{|c|}{ kilo } & 1 & öldürt- \\
\hline oysa & 5 & ziyaret & 2 & \multicolumn{2}{|c|}{ kilometre } & 1 & öldürül- \\
\hline sade & 5 & zor & 2 & \multicolumn{2}{|c|}{ kimi kimi } & 1 & önem ver- \\
\hline sahip & 5 & zorla & 2 & \multicolumn{2}{|c|}{ kimi zaman } & 1 & örnek göster- \\
\hline sakal & 5 & akşam ol- & 2 & \multicolumn{2}{|c|}{ kimlik } & 1 & öt- \\
\hline savaş & 5 & aktar- & 2 & \multicolumn{2}{|c|}{ kimsecik } & 1 & övün- \\
\hline sayfa & 5 & aldan- & 2 & \multicolumn{2}{|c|}{ kiracısız } & 1 & özen göster- \\
\hline sefer & 5 & aldır- & 2 & \multicolumn{2}{|c|}{ kiralık } & 1 & özetle- \\
\hline seyyah & 5 & an- & 2 & \multicolumn{2}{|c|}{ kiremit } & 1 & öznel \\
\hline sicak & 5 & andır- & 2 & \multicolumn{2}{|c|}{ kirli } & 1 & parçala- \\
\hline sözcük & 5 & araştır- & 2 & \multicolumn{2}{|c|}{ kirpi } & 1 & parılda- \\
\hline şura & 5 & art- & 2 & \multicolumn{2}{|c|}{ kişiler arası } & 1 & parlat- \\
\hline tamam & 5 & as- & 2 & \multicolumn{2}{|c|}{ kişilik özellikleri } & 1 & patlat- \\
\hline top & 5 & aşılk ol- & 2 & \multicolumn{2}{|c|}{ kişisel } & 1 & pazarlık yap- \\
\hline tüm & 5 & ayaklan- & 2 & \multicolumn{2}{|c|}{ kitle } & 1 & pençeleş- \\
\hline üzere & 5 & ayıkla- & 2 & \multicolumn{2}{|c|}{ koca yemiş } & 1 & perişan et- \\
\hline varlık & 5 & ayır- & 2 & \multicolumn{2}{|c|}{ kocakarı } & 1 & peşinden git- \\
\hline vasiyet & 5 & azarla- & 2 & \multicolumn{2}{|c|}{ komik } & 1 & peyda ol- \\
\hline yakın & 5 & bade iç- & 2 & \multicolumn{2}{|c|}{ komiser } & 1 & pişman ol- \\
\hline yalan & 5 & bakın- & 2 & \multicolumn{2}{|c|}{ konsol } & 1 & rahat et- \\
\hline yardım & 5 & bastır- & 2 & \multicolumn{2}{|c|}{ konuşma } & 1 & rahatsız et- \\
\hline yarı & 5 & başvur- & 2 & korl & kaklık & 1 & rahatsız ol- \\
\hline yatak & 5 & becer- & 2 & kort & & 1 & rasgel- \\
\hline yavaşça & 5 & beğen- & 2 & kost & tüm & 1 & rast gel- \\
\hline yürek & 5 & belir- & 2 & koşı & & 1 & rastlaş- \\
\hline zengin & 5 & benimse- & 2 & kovr & & 1 & saç- \\
\hline ak- & 5 & beslen- & 2 & kökl & & 1 & saçmala- \\
\hline anlaşıl- & 5 & birik- & 2 & köm & nür & 1 & sağla- \\
\hline atla- & 5 & boz- & 2 & köm & nürcü & 1 & sakinleştir- \\
\hline bilin- & 5 & bozar- & 2 & köp & & 1 & saldır- \\
\hline buluş- & 5 & bulan- & 2 & kös€ & & 1 & samimi ol- \\
\hline değiştir- & 5 & burkul- & 2 & köş€ & e başı & 1 & saptır- \\
\hline dik- & 5 & bük- & 2 & köşe & e yazarlığı & 1 & sarar- \\
\hline dökül- & 5 & bürü- & 2 & köşl & & 1 & sarmala- \\
\hline emret- & 5 & bürün- & 2 & köti & ülük & 1 & sars- \\
\hline engel ol- & 5 & büyüt- & 2 & kren & & 1 & sarsil- \\
\hline & $\begin{array}{r}R \\
\text { Osm }\end{array}$ & $\begin{array}{r}E \text { Dil ve Edebiy } \\
\text { Mahallesi, Mürv } \\
\text { Kadıköy - ISTA } \\
\text { e-post } \\
\text { el: +90 } 50579\end{array}$ & TSO & & $\begin{array}{l}\text { Address } \\
\text { RumeliDE Journ } \\
\text { Osmanağa Maha } \\
\text { Kadıöy - ISTAN } \\
\text { e-mail: editor@ } \\
\text { phone: +90 505 }\end{array}$ & lesi, & $\begin{array}{l}\text { and Literature Studies } \\
\text { ắi Sokak, No:14/8 } \\
34714 \\
216773 \text { o } 616\end{array}$ \\
\hline
\end{tabular}


Türkçenin yabancı dil olarak öğretiminde kullanılan okuma kitaplarındaki söz varlığı ögelerinin incelenmesi / M. Göker; G.

\begin{tabular}{|c|c|c|c|c|c|c|c|}
\hline fark et- & 5 & coş- & 2 & \multicolumn{2}{|c|}{ kristal } & 1 & satın al- \\
\hline güven- & 5 & çağırt- & 2 & \multicolumn{2}{|c|}{ krom } & 1 & sativer- \\
\hline haber ver- & 5 & çak- & 2 & \multicolumn{2}{|c|}{ kumaş } & 1 & savaş- \\
\hline işaretle- & 5 & çekil- & 2 & \multicolumn{2}{|c|}{ kumru } & 1 & savun- \\
\hline kapat- & 5 & çimdikle- & 2 & \multicolumn{2}{|c|}{ kurtuluş } & 1 & savuş- \\
\hline karşılaştır- & 5 & çocuk düşür- & 2 & \multicolumn{2}{|c|}{ kuruluş } & 1 & sayıl- \\
\hline kazan- & 5 & çürü- & 2 & \multicolumn{2}{|c|}{ kuşaklı } & 1 & sebep ol- \\
\hline kes- & 5 & davet et- & 2 & \multicolumn{2}{|c|}{ kuşburnu } & 1 & seçim yap- \\
\hline kiz- & 5 & davran- & 2 & \multicolumn{2}{|c|}{ kuşların } & 1 & seğirt- \\
\hline koru- & 5 & daya- & 2 & \multicolumn{2}{|c|}{ kuvvetle } & 1 & sektir- \\
\hline kov- & 5 & del- & 2 & \multicolumn{2}{|c|}{ kuvvetli } & 1 & selam söyle- \\
\hline öp- & 5 & dene- & 2 & \multicolumn{2}{|c|}{ kuyruk } & 1 & ser- \\
\hline ört- & 5 & dışarı çık- & 2 & \multicolumn{2}{|c|}{ kuyruklu } & 1 & seril- \\
\hline seyret- & 5 & dikil- & 2 & \multicolumn{2}{|c|}{ kuzine } & 1 & serpil- \\
\hline titre- & 5 & dikkat et- & 2 & \multicolumn{2}{|c|}{ küçüklük } & 1 & ses ver- \\
\hline ulaş- & 5 & dinlen- & 2 & \multicolumn{2}{|c|}{ küfe } & 1 & sevil- \\
\hline yola çık- & 5 & dua et- & 2 & \multicolumn{2}{|c|}{ küfür } & 1 & sevinç duy- \\
\hline alay & 4 & düğümle- & 2 & \multicolumn{2}{|c|}{ kültürel } & 1 & seviş- \\
\hline alın & 4 & düşündür- & 2 & \multicolumn{2}{|c|}{ küme } & 1 & seyrekleş- \\
\hline $\operatorname{amaç}$ & 4 & düzenle- & 2 & \multicolumn{2}{|c|}{ kümes } & 1 & Slğg- \\
\hline amca & 4 & ek- & 2 & \multicolumn{2}{|c|}{ kürk } & 1 & slk- \\
\hline asıl & 4 & engelle- & 2 & \multicolumn{2}{|c|}{ küskün } & 1 & sirala- \\
\hline bağır & 4 & eriş- & 2 & \multicolumn{2}{|c|}{ kütüphane } & 1 & siralan- \\
\hline bakış & 4 & gecik- & 2 & \multicolumn{2}{|c|}{ laden } & 1 & sirtla- \\
\hline balkon & 4 & ger- & 2 & \multicolumn{2}{|c|}{ lakin } & 1 & siva- \\
\hline bardak & 4 & gerek gör- & 2 & lan & & 1 & Siz- \\
\hline basit & 4 & gezin- & 2 & layı & & 1 & sızlan- \\
\hline be & 4 & göm- & 2 & levh & & 1 & silin- \\
\hline bilet & 4 & göz gezdir- & 2 & leyl & laki & 1 & siliniver- \\
\hline boyun & 4 & hayal et- & 2 & leyl & & 1 & silk- \\
\hline cariye & 4 & hecele- & 2 & lira & clk & 1 & sin- \\
\hline çarşaflı & 4 & hesapla- & 2 & lisa & & 1 & sinirlen- \\
\hline çimen & 4 & heyecanlan- & 2 & lod & & 1 & soğut- \\
\hline çivi & 4 & hıçkır- & 2 & lok & $\mathrm{ma}$ & 1 & sokul- \\
\hline çizgi & 4 & homurdan- & 2 & $\mathrm{ma}$ & azallah & 1 & sol- \\
\hline dağınık & 4 & hoşlan- & 2 & $\mathrm{ma}$ & cun & 1 & somurt- \\
\hline dün & 4 & $1 \sin -$ & 2 & $\mathrm{ma}$ & & 1 & söktür- \\
\hline ecinni & 4 & içir- & 2 & $\mathrm{ma}$ & dam & 1 & sön- \\
\hline efendim & 4 & ifade et- & 2 & $\mathrm{ma}$ & ğrur & 1 & söylen- \\
\hline erkek & 4 & ilave et- & 2 & $\mathrm{ma}$ & hkum & 1 & söz söyle- \\
\hline & & $\begin{array}{r}\text { E Dil ve Edebiyat } \\
\text { Mahallesi, Mürver } C \\
\text { Kadıköy - İSTANB } \\
\text { e-posta: } \\
\text { el: }+9050579581\end{array}$ & 'is & & $\begin{array}{l}\text { Address } \\
\text { RumeliDI } \\
\text { Osmanağ } \\
\text { Kadiköy - } \\
\text { e-mail: e } \\
\text { phone: + }\end{array}$ & lisi & $\begin{array}{l}\text { and Literature Studies } \\
\text { eği Sokak, No:14/8 } \\
34714 \\
216773 \text { o } 616\end{array}$ \\
\hline
\end{tabular}


Examination of vocabulary items in reading books used in teaching Turkish as a foreign language / M. Göker; G. Göçen (pp. 407-446)

\begin{tabular}{|c|c|c|c|c|c|c|c|}
\hline erken & 4 & incel- & 2 & \multicolumn{2}{|c|}{ mahsus } & 1 & sözünü et- \\
\hline eskici & 4 & incele- & 2 & \multicolumn{2}{|c|}{ mama } & 1 & sun- \\
\hline eşya & 4 & isimlendir- & 2 & \multicolumn{2}{|c|}{ manevi } & 1 & susa- \\
\hline evet & 4 & izle- & 2 & \multicolumn{2}{|c|}{ manevra } & 1 & sürç- \\
\hline ey & 4 & karıştır- & 2 & \multicolumn{2}{|c|}{ mangal } & 1 & sürükle- \\
\hline eyvah & 4 & katlan- & 2 & \multicolumn{2}{|c|}{ mantolu } & 1 & süsle- \\
\hline farklılık & 4 & kız ver- & 2 & \multicolumn{2}{|c|}{ marpuç } & 1 & şahit ol- \\
\hline fena & 4 & kokla- & 2 & \multicolumn{2}{|c|}{ marul } & 1 & şaka yap- \\
\hline fener & 4 & koştur- & 2 & \multicolumn{2}{|c|}{ masraf } & 1 & şakı- \\
\hline fikir & 4 & kurgula- & 2 & \multicolumn{2}{|c|}{ maşa } & 1 & şarkı söyle- \\
\hline gerçi & 4 & kurut- & 2 & \multicolumn{2}{|c|}{ maşallah } & 1 & şehit ol- \\
\hline görsel & 4 & musallat ol- & 2 & \multicolumn{2}{|c|}{ mavi } & 1 & şifa ver- \\
\hline güneş & 4 & numaralandir- & 2 & \multicolumn{2}{|c|}{ maydanoz } & 1 & şikayet et- \\
\hline güz & 4 & oluş- & 2 & \multicolumn{2}{|c|}{ maymun } & 1 & şişir- \\
\hline halbuki & 4 & otla- & 2 & \multicolumn{2}{|c|}{ mecburen } & 1 & tahmin et- \\
\hline hani & 4 & oturt- & 2 & \multicolumn{2}{|c|}{ meçhul } & 1 & tahsildarlık yap- \\
\hline hayvan & 4 & öde- & 2 & \multicolumn{2}{|c|}{ meğerki } & 1 & takdir et- \\
\hline hile & 4 & öksür- & 2 & \multicolumn{2}{|c|}{ mekan } & 1 & taklit et- \\
\hline hizmetçi & 4 & ör- & 2 & \multicolumn{2}{|c|}{ mektupçu } & 1 & talip ol- \\
\hline huy & 4 & özle- & 2 & \multicolumn{2}{|c|}{ melek } & 1 & tamir et- \\
\hline içeri & 4 & özlem duy- & 2 & \multicolumn{2}{|c|}{ memleketli } & 1 & tanımla- \\
\hline ilan & 4 & parçalan- & 2 & \multicolumn{2}{|c|}{ menfaat } & 1 & tanış ol- \\
\hline ilginç & 4 & parla- & 2 & \multicolumn{2}{|c|}{ merak içinde } & 1 & tanit- \\
\hline ilişki & 4 & pes et- & 2 & \multicolumn{2}{|c|}{ meraklı } & 1 & tara- \\
\hline inanç & 4 & piş- & 2 & \multicolumn{2}{|c|}{ merhamet } & 1 & tartış- \\
\hline incecik & 4 & reddet- & 2 & mer & rhem & 1 & taşın- \\
\hline iskete & 4 & sabret- & 2 & mer & rhum & 1 & tazminat al- \\
\hline iyilik & 4 & sap- & 2 & mer & rkez & 1 & tebessüm et- \\
\hline jandarma & 4 & sar- & 2 & mer & rkezi & 1 & tedavi gör- \\
\hline kahraman & 4 & savrul- & 2 & mes & slek & 1 & tedirgin et- \\
\hline kartal & 4 & sertleş- & 2 & mes & & 1 & teklif et- \\
\hline kavga & 4 & ses çıkar- & 2 & meş & & 1 & tekme vur- \\
\hline kavuk & 4 & sevdir- & 2 & met & tanet & 1 & telaffuz et- \\
\hline kemer & 4 & sevin- & 2 & met & & 1 & telaş et- \\
\hline kılıklı & 4 & sohbet et- & 2 & me & vcut & 1 & telefon et- \\
\hline kısım & 4 & sökül- & 2 & mil & attan önce & 1 & temas et- \\
\hline kocaman & 4 & söyleş- & 2 & $\min$ & nare & 1 & tembih et- \\
\hline koç & 4 & sula- & 2 & $\min$ & nder & 1 & temizle- \\
\hline kolay & 4 & şaş- & 2 & $\min$ & iicik & 1 & temizlen- \\
\hline konak & 4 & şiş- & 2 & $\min$ & himini & 1 & temsil et- \\
\hline & $\begin{array}{r}R \\
\text { Osm }\end{array}$ & $\begin{array}{l}\text { E Dil ve Edebiyat Ara } \\
\text { Mahallesi, Mürver Çiç } \\
\text { Kadıköy - İSTANBUL } \\
\text { e-posta: edi } \\
\text { el: +90 } 5057958124 \text {, }\end{array}$ & $\begin{array}{l}\text { iso } \\
\text { TÜ }\end{array}$ & $\begin{array}{l}\text { Ires } \\
\text { gisi } \\
4 / 8 \\
714 \\
\text { com } \\
616\end{array}$ & $\begin{array}{l}\text { Address } \\
\text { RumeliDE Jo } \\
\text { Osmanağa M } \\
\text { Kadıköy - IST } \\
\text { e-mail: editc } \\
\text { phone: +9o }\end{array}$ & lesi & $\begin{array}{l}\text { and Literature Studies } \\
\text { eği Sokak, No:14/8 } \\
34714 \\
16773 \text { o } 616\end{array}$ \\
\hline
\end{tabular}


Türkçenin yabancı dil olarak öğretiminde kullanılan okuma kitaplarındaki söz varlığı ögelerinin incelenmesi / M. Göker; G.

\begin{tabular}{|c|c|c|c|c|c|c|c|}
\hline kucak & 4 & tahammül et- & 2 & \multicolumn{2}{|c|}{ mizah } & 1 & tenhalaş- \\
\hline kuru & 4 & takip et- & 2 & \multicolumn{2}{|c|}{ mizahi } & 1 & terle- \\
\hline lamba & 4 & tanın- & 2 & \multicolumn{2}{|c|}{ mor } & 1 & teselli et- \\
\hline makine & 4 & taran- & 2 & \multicolumn{2}{|c|}{ morartı } & 1 & tıkan- \\
\hline manzara & 4 & tedavi et- & 2 & \multicolumn{2}{|c|}{ motif } & 1 & tıkırdat- \\
\hline memleket & 4 & tekrar et- & 2 & \multicolumn{2}{|c|}{ muallim } & 1 & tıraş ol- \\
\hline mescit & 4 & tercih et- & 2 & \multicolumn{2}{|c|}{ muhabirlik } & 1 & tomurcuklan- \\
\hline misafir & 4 & tereddüt et- & 2 & \multicolumn{2}{|c|}{ muhakeme } & 1 & tortop ol- \\
\hline mukaddes & 4 & teşekkür et- & 2 & \multicolumn{2}{|c|}{ muhakkak } & 1 & toz al- \\
\hline neredeyse & 4 & tokat at- & 2 & \multicolumn{2}{|c|}{ muhal } & 1 & tutuklan- \\
\hline of & 4 & tuttur- & 2 & \multicolumn{2}{|c|}{ muhtaç } & 1 & tutul- \\
\hline oldukça & 4 & tutun- & 2 & \multicolumn{2}{|c|}{ mundar } & 1 & tüket- \\
\hline oyuncak & 4 & ulaştır- & 2 & \multicolumn{2}{|c|}{ mutsuz } & 1 & tüt- \\
\hline oyuncu & 4 & um- & 2 & \multicolumn{2}{|c|}{ muvafakat } & 1 & uçuş- \\
\hline öbür & 4 & utan- & 2 & \multicolumn{2}{|c|}{ mücadele } & 1 & uğulda- \\
\hline öf & 4 & uyandır- & 2 & \multicolumn{2}{|c|}{ müezzin } & 1 & uğurla- \\
\hline ökse & 4 & uydur- & 2 & \multicolumn{2}{|c|}{ mühimce } & 1 & umursa- \\
\hline örnek & 4 & üzül- & 2 & \multicolumn{2}{|c|}{ mülayim } & 1 & utandır- \\
\hline özellikle & 4 & vaat et- & 2 & \multicolumn{2}{|c|}{ mütevazi } & 1 & uy- \\
\hline parlak & 4 & vasiyet et- & 2 & \multicolumn{2}{|c|}{ müze } & 1 & uyuş- \\
\hline peki & 4 & yağ- & 2 & \multicolumn{2}{|c|}{ nadir } & 1 & uza- \\
\hline peri bacası & 4 & yaklaştır- & 2 & \multicolumn{2}{|c|}{ nakil } & 1 & uzak dur- \\
\hline pervaz & 4 & yardım et- & 2 & \multicolumn{2}{|c|}{ namaz } & 1 & uzun sür- \\
\hline peşin & 4 & yarıl- & 2 & \multicolumn{2}{|c|}{ namuslu } & 1 & ürküt- \\
\hline posta & 4 & yatır- & 2 & \multicolumn{2}{|c|}{ nane } & 1 & üşen- \\
\hline ruh & 4 & yayımlan- & 2 & nar & & 1 & üşü- \\
\hline saçlı & 4 & yet- & 2 & nar & çiçeği & 1 & üşüş- \\
\hline sapsarı & 4 & yı ̆̆ll- & 2 & naz & & 1 & üz- \\
\hline sekiz & 4 & yıkıl- & 2 & naz & arlık & 1 & var et- \\
\hline serçe & 4 & yırt- & 2 & ne 1 & ne ne & 1 & $\begin{array}{l}\text { vasiyeti yerine } \\
\text { getir- }\end{array}$ \\
\hline sessiz & 4 & yok et- & 2 & ne 1 & ne ne ne & 1 & vedalaş- \\
\hline sevgi & 4 & yönel- & 2 & nefi & & 1 & vızılda- \\
\hline seyahatname & 4 & yüksel- & 2 & nef & & 1 & yağdır- \\
\hline sinif & 4 & yürüt- & 2 & neh & & 1 & yakalan- \\
\hline sirasında & 4 & yüz- & 2 & nen & & 1 & yakar- \\
\hline soğuk & 4 & mayis & 1 & nen & nse tavuğu & 1 & yakınlık duy- \\
\hline sürgün & 4 & eylül & 1 & nen & & 1 & yanaş- \\
\hline şart & 4 & çarşamba & 1 & nes & nel & 1 & yanit ver- \\
\hline tarak & 4 & cuma & 1 & net & & 1 & yans1- \\
\hline & $\begin{array}{r}R \\
\text { Osm } \\
\end{array}$ & $\begin{array}{l}\text { E Dil ve Edebiyat Ar } \\
\text { Mahallesi, Mürver Çi } \\
\text { Kadıköy - ÍSTANBU } \\
\text { e-posta: ed } \\
\text { el: +90 505 795812 }\end{array}$ & 1 & 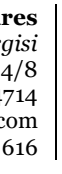 & $\begin{array}{l}\text { Address } \\
\text { RumeliDE Jou } \\
\text { Osmanağa Ma } \\
\text { Kadıöy - IST } \\
\text { e-mail: edito } \\
\text { phone: }+905\end{array}$ & 795 & $\begin{array}{l}\text { and Literature Studies } \\
\text { ắi Sokak, No:14/8 } \\
34714 \\
216773 \text { o } 616\end{array}$ \\
\hline
\end{tabular}


Examination of vocabulary items in reading books used in teaching Turkish as a foreign language / M. Göker; G. Göçen (pp. 407-446)

\begin{tabular}{|c|c|c|c|c|c|c|c|}
\hline $\operatorname{tarz}$ & 4 & cumartesi & 1 & \multicolumn{2}{|c|}{ netice } & 1 & yansit- \\
\hline $\operatorname{tas}$ & 4 & haz & 1 & \multicolumn{2}{|c|}{ neyse } & 1 & yapıl- \\
\hline tavuk & 4 & haziran & 1 & \multicolumn{2}{|c|}{ nice } & 1 & yapıştır- \\
\hline titrek & 4 & pazar & 1 & \multicolumn{2}{|c|}{ nihayetinde } & 1 & yaptır- \\
\hline tozluklu & 4 & nisan & 1 & \multicolumn{2}{|c|}{ nijerli } & 1 & yara- \\
\hline tuhaf & 4 & temmuz & 1 & \multicolumn{2}{|c|}{ niyaz } & 1 & yarat- \\
\hline uçak & 4 & $\mathrm{a}$ & 1 & \multicolumn{2}{|c|}{ niyet } & 1 & yardım dile- \\
\hline ufak & 4 & aa & 1 & \multicolumn{2}{|c|}{ nizam } & 1 & yardım iste- \\
\hline vay & 4 & aаaа & 1 & \multicolumn{2}{|c|}{ noktasız } & 1 & yas tut- \\
\hline yaşlı & 4 & abdest & 1 & \multicolumn{2}{|c|}{ not } & 1 & yaslan- \\
\hline yoksa & 4 & abla & 1 & \multicolumn{2}{|c|}{ odun } & 1 & yaşama veda et- \\
\hline yolcu & 4 & acayip & 1 & \multicolumn{2}{|c|}{ okul arkadaşı } & 1 & yaşar- \\
\hline yön & 4 & aceleci & 1 & \multicolumn{2}{|c|}{ okul çağı } & 1 & yaşlan- \\
\hline zihin & 4 & acımasız & 1 & \multicolumn{2}{|c|}{ okul çıkışı } & 1 & yayımla- \\
\hline açll- & 4 & aç & 1 & \multicolumn{2}{|c|}{ okullu } & 1 & yayınla- \\
\hline ağırlaş- & 4 & açıkça & 1 & \multicolumn{2}{|c|}{ olay örgüsü } & 1 & yazık ol- \\
\hline alış- & 4 & açıkçası & 1 & \multicolumn{2}{|c|}{ olumlu } & 1 & yedir- \\
\hline ayağa kalk- & 4 & açsız & 1 & \multicolumn{2}{|c|}{ olup biten } & 1 & yelten- \\
\hline bahset- & 4 & adamakıllı & 1 & \multicolumn{2}{|c|}{ on bin } & 1 & yemek yap- \\
\hline boğ- & 4 & adet & 1 & \multicolumn{2}{|c|}{ on dört } & 1 & yemin et- \\
\hline bozul- & 4 & adımlık & 1 & \multicolumn{2}{|c|}{ on yedi } & 1 & yen- \\
\hline buyur- & 4 & aferin & 1 & \multicolumn{2}{|c|}{ onca } & 1 & yere yığılıver- \\
\hline çömel- & 4 & ağırlık & 1 & \multicolumn{2}{|c|}{ orta öğrenim } & 1 & yerinden oynat- \\
\hline dağll- & 4 & ağrı & 1 & \multicolumn{2}{|c|}{ ortak } & 1 & yetiştir- \\
\hline dal- & 4 & ahbap & 1 & \multicolumn{2}{|c|}{ ortam } & 1 & ylğ- \\
\hline dokun- & 4 & ahenk & 1 & orta & aoyunu & 1 & yll- \\
\hline dol- & 4 & ahır & 1 & orta & äöğrenim & 1 & yıllan- \\
\hline düzelt- & 4 & ahir zaman & 1 & oru & & 1 & yıpran- \\
\hline eğlen- & 4 & ahmak & 1 & otur & z bir & 1 & yırtıl- \\
\hline eri- & 4 & ailece & 1 & öbü & ir alem & 1 & yok ol- \\
\hline firla- & 4 & ailecek & 1 & ödü & & 1 & yol- \\
\hline getirt- & 4 & $\mathrm{ak}$ & 1 & öfke & & 1 & yol arkadaşlığı et \\
\hline görüş- & 4 & akım & 1 & öğle & & 1 & yola düzül- \\
\hline havalan- & 4 & akış & 1 & öğle & vakti & 1 & yolla- \\
\hline haykır- & 4 & akla yakın & 1 & öğle & & 1 & yor- \\
\hline iyileş- & 4 & aksi & 1 & önc & & 1 & yorumla- \\
\hline kap- & 4 & alaka & 1 & öne & & 1 & yumuşa- \\
\hline kapa- & 4 & albüm & 1 & öne & msiz & 1 & yut- \\
\hline karşıla- & 4 & alem & 1 & önü & isra & 1 & yuvarlan- \\
\hline & $\begin{array}{r}R \\
\text { Osm } \\
\end{array}$ & $\begin{array}{r}\text { E Dil ve Edebiyat } \\
\text { Mahallesi, Mürver } \\
\text { Kadıköy - ISTAN } \\
\text { e-posta: } \\
\text { tel: }+905057958\end{array}$ & & $\begin{array}{l}\text { |res } \\
\text { gisi } \\
4 / 8 \\
714 \\
\mathrm{com} \\
616\end{array}$ & $\begin{array}{l}\text { Address } \\
\text { RumeliDE Jo } \\
\text { Osmanağa M } \\
\text { Kadıköy - IST } \\
\text { e-mail: editc } \\
\text { phone: +90 }\end{array}$ & $\begin{array}{l}\text { lesi, } \\
\text { BUL } \\
\text { rume } \\
795\end{array}$ & $\begin{array}{l}\text { and Literature Studies } \\
\text { cŏi Sokak, No:14/8 } \\
34714 \\
216773 \text { o } 616\end{array}$ \\
\hline
\end{tabular}




\begin{tabular}{|c|c|c|c|c|c|c|c|}
\hline kon- & 4 & alev & 1 & önyargılı & 1 & yükle- & 1 \\
\hline kovala- & 4 & alıcı & 1 & özgün & 1 & yüklen- & 1 \\
\hline kurtul- & 4 & alınlık & 1 & özgürlük & 1 & zenginleştir- & 1 \\
\hline kuru- & 4 & alışık & 1 & paket & 1 & ziyafet ver- & 1 \\
\hline kükre- & 4 & alışkın & 1 & palto & 1 & zorunda kal- & 1 \\
\hline merak+et- & 4 & alışveriş & 1 & pardon & 1 & & \\
\hline \multicolumn{3}{|c|}{ Toplam Sözcük Sayısı } & & 19.465 & & Farklı) & \\
\hline
\end{tabular}

Ek 2. İncelenen kitapta yer alan ikilemeler ve sıklık sayıları

\begin{tabular}{|c|c|c|c|c|c|}
\hline İkilemeler & $\begin{array}{l}\text { Siklık } \\
\text { Sayısı }\end{array}$ & İkilemeler & $\begin{array}{l}\text { Siklık } \\
\text { Sayısı }\end{array}$ & İkilemeler & $\begin{array}{l}\text { S1klık } \\
\text { Sayısı }\end{array}$ \\
\hline ağır ağır & 6 & biçim biçim & 1 & kocaman kocaman & 1 \\
\hline kendi kendine & 6 & bir bir & 1 & konu komşu & 1 \\
\hline yavaş yavaş & 6 & bol bol & 1 & koştura koştura & 1 \\
\hline pirıl pirıl & 5 & boylu poslu & 1 & küme küme & 1 \\
\hline ara sira & 4 & büyüte büyüte & 1 & lapa lapa & 1 \\
\hline görür görmez & 4 & canlı canlı & 1 & mahsun mahsun & 1 \\
\hline uzun uzun & 4 & civil cıvil & 1 & mini mini & 1 \\
\hline birer birer & 3 & çabuk çabuk & 1 & oda oda & 1 \\
\hline büyük büyük & 3 & çalgı çağanak & 1 & okuya okuya & 1 \\
\hline parça parça & 3 & çıkar çıkmaz & 1 & pembe pembe & 1 \\
\hline sik sik & 3 & dalıp dalıp & 1 & peşi sıra & 1 \\
\hline sıkı sıkı & 3 & derinden derine & 1 & renk renk & 1 \\
\hline şaşkın şaşkın & 3 & deste deste & 1 & sarsıla sarsıla & 1 \\
\hline ufak tefek & 3 & doğrudan doğruya & 1 & sendeleye sendeleye & 1 \\
\hline bile bile & 2 & dura dura & 1 & sessiz sedasız & 1 \\
\hline çoluk çocuk & 2 & eğri büğrü & 1 & sessiz sessiz & 1 \\
\hline çoluklu çocuklu & 2 & eş dost & 1 & seve seve & 1 \\
\hline derli toplu & 2 & firll firll & 1 & seyrede seyrede & 1 \\
\hline düğün dernek & 2 & gecesi gecesine & 1 & sıkı sıkıya & 1 \\
\hline gide gide & 2 & gelir gelmez & 1 & sora sora & 1 \\
\hline girer girmez & 2 & girıl girll & 1 & söyler söylemez & 1 \\
\hline hızlı hızlı & 2 & gizli gizli & 1 & sürü sürü & 1 \\
\hline kısa kısa & 2 & haykıra haykıra & 1 & sürüne sürüne & 1 \\
\hline titreye titreye & 2 & hıçkıra hıçkıra & 1 & süze süze & 1 \\
\hline yan yana & 2 & iç içe & 1 & şakır şakır & 1 \\
\hline yer yer & 2 & içli içli & 1 & şarıl şarıl & 1 \\
\hline yırtık pırtık & 2 & iri yarı & 1 & tatlı tatlı & 1 \\
\hline ablak ablak & 1 & itişme kakışma & 1 & üç dört & 1 \\
\hline acele acele & 1 & kalın kalın & 1 & varsa yoksa & 1 \\
\hline \multicolumn{3}{|c|}{$\begin{array}{r}\text { Adres } \\
\text { RumeliDE Dil ve Edebiyat Araştrrmalart Dergisi } \\
\text { Osmanağa Mahallesi, Mürver Ciçeği Sokak, No:14/8 } \\
\text { Kadıköy - İSTANBUL / TÜRKiYE } 14714 \\
\text { e-posta: editor@rumelide.com } \\
\text { tel: +90 505 7958124, +90 216 773 o } 616\end{array}$} & $\begin{array}{l}\text { Address } \\
\text { RumeliDE Journa } \\
\text { Osmanağa Mahall } \\
\text { Kadıköy - ISTANB } \\
\text { e-mail: editor@r } \\
\text { phone: +90 505 }\end{array}$ & $\begin{array}{l}\text { f Language and Literature Studies } \\
\text {, Mürver Çiçeği Sokak, No:14/8 } \\
\text { L/ TURKEY } 34714 \\
\text { elide.com, } \\
58124,+90216773 \text { o } 616\end{array}$ & \\
\hline
\end{tabular}


Examination of vocabulary items in reading books used in teaching Turkish as a foreign language / M. Göker; G. Göçen (pp. 407-446)

\begin{tabular}{llllll} 
aheste aheste & 1 & kana kana & 1 & yanıp tutuş- & 1 \\
ak pak & 1 & kara kara & 1 & yığın yı̆̆ın & 1 \\
arada sırada & 1 & kara kuru & 1 & yumuşak yumuşak & 1 \\
ardı sıra & 1 & karı koca & 1 & zaman zaman & 1 \\
bakar bakmaz & 1 & katıla katıla & 1 & \\
baştan başa & 1 & kelime kelime & 1 & & \\
\hline
\end{tabular}

Toplam ikileme sayısı

158 (Toplam) 103 (Farklı)

Ek 3. İncelenen kitapta yer alan deyimler ve sıklık sayıları

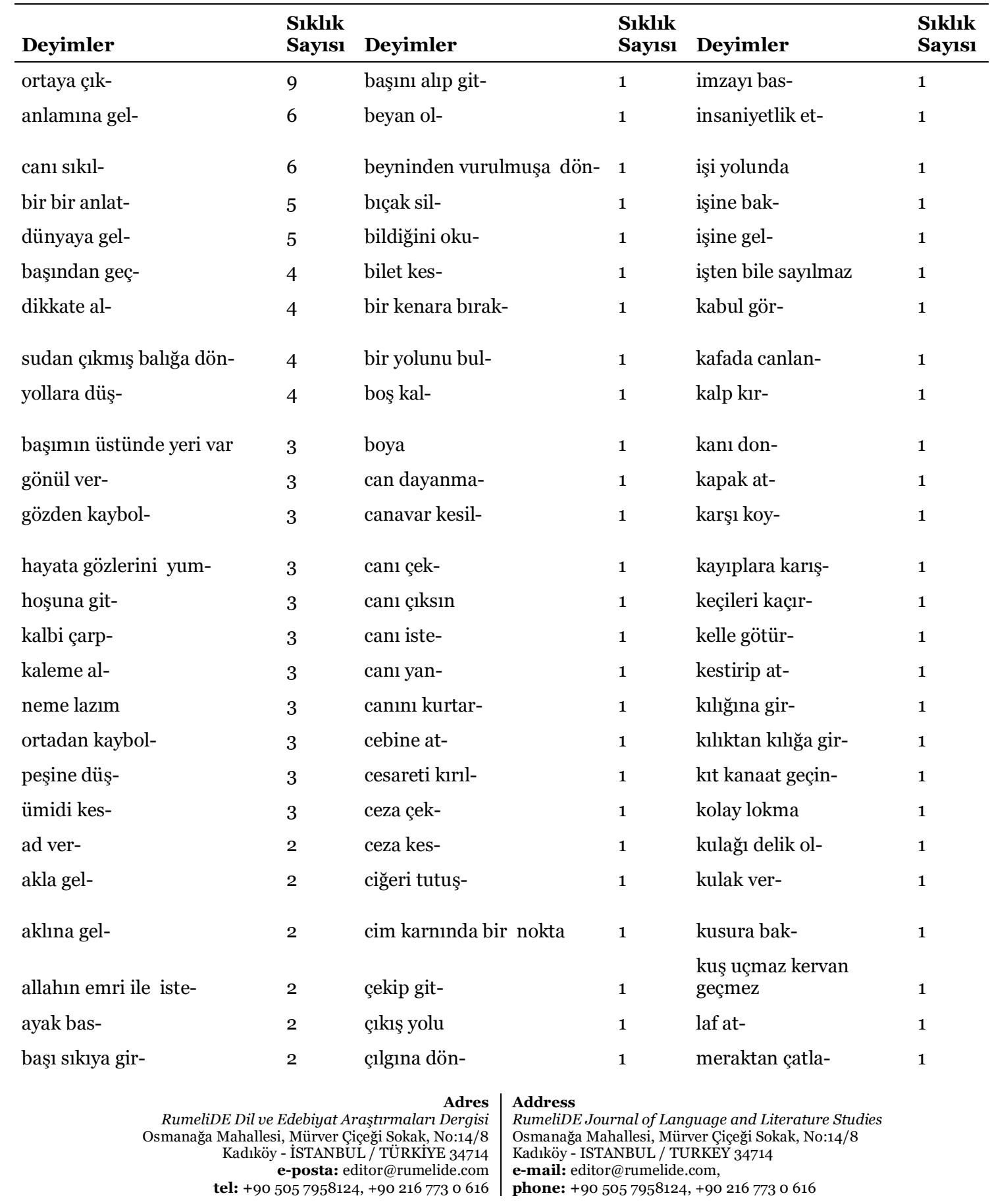


Türkçenin yabancı dil olarak öğretiminde kullanılan okuma kitaplarındaki söz varlığı ögelerinin incelenmesi / M. Göker; G.

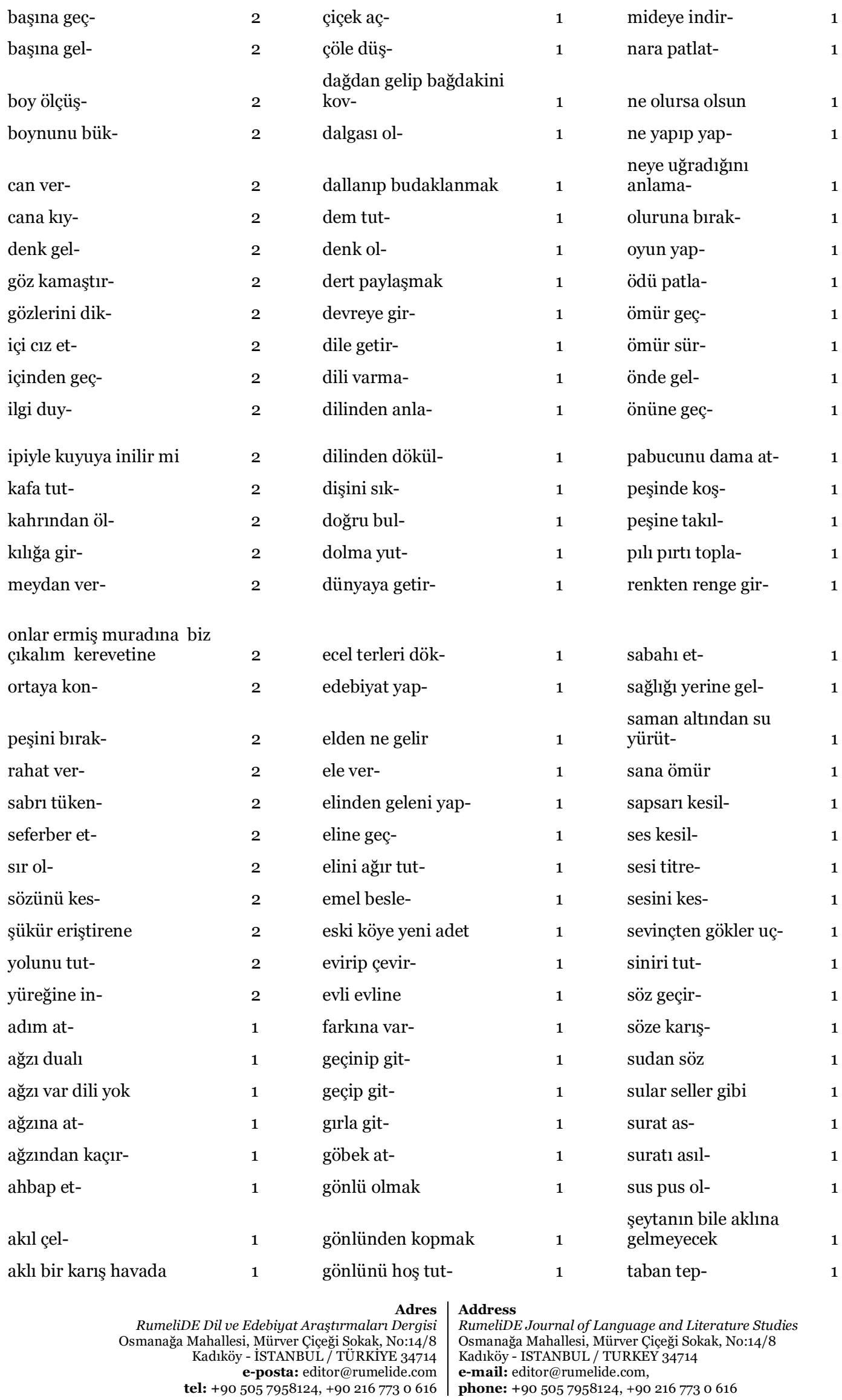


Examination of vocabulary items in reading books used in teaching Turkish as a foreign language / M. Göker; G. Göçen (pp. 407-446)

\begin{tabular}{|c|c|c|c|c|}
\hline aklı er- & 1 & gönlünü serin tut- & 1 & takati kalma- \\
\hline $\begin{array}{l}\text { aklımın kıyısından bile } \\
\text { geçme- }\end{array}$ & 1 & gönül al- & 1 & tavir sergile- \\
\hline aklına düş- & 1 & gönül almak & 1 & tepesi at- \\
\hline aklına geleni söyle- & 1 & gönül koymak & 1 & uçup git- \\
\hline aklına getir- & 1 & gönülden çıkarmak & 1 & uğurlar olsun \\
\hline aklını başından al- & 1 & gönülden sevmek & 1 & uyku uyutma- \\
\hline alıp başını git- & 1 & göz alabildiğine & 1 & ümidi kaybet- \\
\hline allah bilir & 1 & göz önüne al- & 1 & üstüme iyilik sağlık \\
\hline altında kal- & 1 & gözden düş- & 1 & üstüne yok \\
\hline aman yarabbi & 1 & gözleri karar- & 1 & vakit geçir- \\
\hline ana baba günü & 1 & gözleri parla- & 1 & yerin dibine geçir- \\
\hline arkasına düş- & 1 & gözleri yaşar- & 1 & yerinde say- \\
\hline aslan ağzında & 1 & gözlerini kamaştır- & 1 & yerinden firla- \\
\hline ateş püskür- & 1 & gözünde silin- & 1 & $\begin{array}{l}\text { yıldırım vurulmuşa } \\
\text { dön- }\end{array}$ \\
\hline avazı çıktığı kadar haykır- & 1 & gözüne kestir- & 1 & yol al- \\
\hline ayın on dördü gibi & 1 & gözünü alama- & 1 & yol göster- \\
\hline ayna tut- & 1 & hayrette kal- & 1 & yolu düş- \\
\hline ayrı dünyaların insanı & 1 & hiç olmazsa & 1 & yolundan çevir- \\
\hline az gitmiş uz gitmiş & 1 & hoş gel- & 1 & yüreği burkul- \\
\hline az kalsın & 1 & huzur bul- & 1 & yüreği hop et- \\
\hline bağlantı kur- & 1 & içi geç- & 1 & yüreği yumuşa- \\
\hline bağlı kal- & 1 & içi parçalan- & 1 & yüzü gül- \\
\hline bağrına bas- & 1 & içini aç- & 1 & yüzünde güller aç- \\
\hline bahane bul- & 1 & içini çek- & 1 & yüzünden oku- \\
\hline bakış at- & 1 & içini yak- & 1 & yüzüne gül- \\
\hline başı beladan kurtulmaz & 1 & iki gözü iki çeşme & 1 & zararı dokun- \\
\hline başına bir felaket gel- & 1 & ileri gel- & 1 & zora sok- \\
\hline başında bul- & 1 & ileri git- & 1 & \\
\hline
\end{tabular}

Toplam deyim sayısı

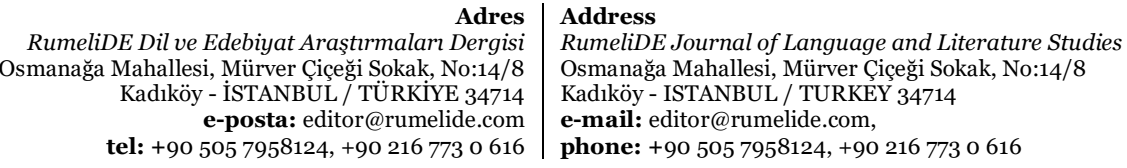

